\title{
Expression and Function of Aquaporin 1 in Hypoxia-Induced Pulmonary Hypertension
}

\section{DISSERTATION}

\author{
ZUR \\ ERLANGUNG DER NATURWISSENSCHAFTLICHEN DOKTORWÜRDE \\ (DR. SC. NAT.) \\ VORGELEGT DER \\ MATHEMATISCH-NATURWISSENSCHAFTLICHEN FAKULTÄT \\ DER \\ UNIVERSITÄT ZÜRICH \\ VON \\ Claudio Schuoler \\ VON \\ SUMVITG GR
}

Promotionskommission:

Prof. Dr. med. vet. Max Gassmann (Vorsitz)

Dr. Matthias Brock (Leitung Der DisSERTation)

Prof. Dr. Christian Grimm

Prof. Dr. Med. Malcolm Kohler

PD DR. MED. LARS C. HubER

ZÜRICH, 2017 



\section{Table of Contents}

SUMMARY

ZUSAMMENFASSUNG

\section{INTRODUCTION} 1

1.1 Pulmonary Hypertension

1.2 Aquaporins

1.3 Objectives

\section{Aquaporin 1 Controls the Functional Phenotype of Pulmonary Smooth} Muscle Cells in Hypoxia-Induced Pulmonary Hypertension

2.1 Abstract

2.2 Introduction

$2.3 \quad$ Methods

2.4 Results

2.5 Discussion

2.6 References

2.7 Supplementary Material

3 SYNTHESIS

3.1 Main Findings and Implications

3.2 Limitations

3.3 Outlook

REFERENCES

\section{APPENDIX}

Abbreviations 


\section{SUMMARY}

Pulmonary hypertension (PH) is an umbrella term used for the haemodynamic sequelae of many different conditions that all result in elevation of the mean pulmonary arterial pressure (exceeding $25 \mathrm{mmHg}$ at rest), where chronic hypoxia is considered a major trigger. $\mathrm{PH}$ is a severe condition that leads to right heart failure and death when left untreated. It is characterized by the triad of vasoconstriction, microthrombotic events, and remodelling of the small pulmonary arteries. Of these changes, vascular remodelling due to the proliferation and migration of vascular smooth muscle and endothelial cells, causing progressive obliteration of the vascular lumen, is arguably the most important pathogenetic factor in $\mathrm{PH}$ and, since no therapy is available that directly targets remodelling yet, still defines chronicity and incurability of the disease. Therefore, novel concepts that unravel the pathobiology underlying the process of vascular remodelling and, as such, could provide the basis for a new generation of treatment strategies ("reverse remodelling") are utterly needed. Chronic exposure to hypoxia represents one of the best-established pathogenic models for pulmonary arterial vasoconstriction and vascular remodelling. In this regard, the aquaporins (AQPs), a class of membrane water channels responsible for rapid trans-epithelial fluid transport, appear as a novel interesting target. The mammalian AQP family consists of 13 different subsets, which are expressed in multiple organs, including the lungs, and are involved in additional physiological processes such as cell migration, proliferation and angiogenesis. It has been shown that hypoxia can modulate the expression of AQP1 in the lungs of mice indicating an important physiological role of AQP1 in the adaption to oxygen depletion. Along that line, a recent work demonstrated the presence of AQP1 in pulmonary vasculature of rats and the regulation of AQP1 by chronic exposure to hypoxia. In a previous study the regulation of rat pulmonary smooth muscle migration by AQP1 was assessed and was found to be essential for hypoxia-induced smooth muscle migration.

Since the interplay between AQP1, hypoxia and PH has not been directly addressed so far, the present thesis was conducted to investigate the physiological role of AQP1 in the pathobiology of vascular remodelling in hypoxia-induced $\mathrm{PH}$. This study was designed to characterize the expression and function of AQP1 in human vascular cells derived from pulmonary arteries and in the mouse model of hypoxia-induced PH. By focusing on AQP1, 
we expected novel insights into the pathogenesis of the disease that might lead to the development of novel therapies.

In this $\mathrm{PhD}$ thesis, I could provide evidence that (i) exposure of human pulmonary vascular cells to hypoxia significantly induced the expression of AQP1. Similarly, (ii) levels of AQP1 were found to be upregulated in lungs of mice with hypoxia-induced $\mathrm{PH}$. The functional role of AQP1 was further tested in human pulmonary artery smooth muscle cells (HPASMC) demonstrating that (iii) depletion of AQP1 with GapmeR inhibitors reduced the migratory potential, proliferation, and, conversely, induced apoptosis of these cells. Along that line, (iv) transient transfection with a vector overexpressing AQP1 led to enhanced proliferation and migration rates. This effect was associated with (v) higher expression of the tumour suppressor gene p53 when AQP1 was silenced. Conversely, expression levels of p53 were found to be decreased in HPASMC exposed to hypoxia. Using the mouse model of hypoxiainduced PH, (vi) application of GapmeR inhibitors targeting AQP1 abated the hypoxiainduced upregulation of AQP1 and, of note, reversed PH by decreasing both right ventricular pressure and right ventricular hypertrophy back to the levels of control mice.

In conclusion, to the best of our knowledge, this is the first report on therapeutic intervention of AQP1 in the context of PH. Our data suggest an important functional role of AQP1 in the pathobiology of hypoxia-induced $\mathrm{PH}$. Since vascular remodelling is currently not sufficiently addressed by $\mathrm{PH}$ therapies, these findings have implications both for our pathogenetic understanding and novel therapeutic approaches. 


\section{ZUSAMMENFASSUNG}

Das Krankheitsbild der pulmonalen Hypertonie (PH) betrifft die kleinen Blutgefässe in der Lunge und umfasst eine Vielzahl an Erkrankungen, die zu einer drastischen Druckerhöhung im Lungenkreislauf (mittlerer pulmonal-arterieller Druck von $\geq 25 \mathrm{mmHg}$ ) und innert weniger Jahre zu einer rechtsventrikulären Insuffizienz und schlussendlich zum Tod führt. Interessanterweise münden die meisten Auslöser der pulmonalen Hypertonie in eine gemeinsame pathogenetische Endstrecke. Diese besteht aus einer Trias von übermässiger Engstellung der Gefässe (Vasokonstriktion) in der Lunge, lokale kleine Blutgerinnseln (Mikrothrombosen) und einem charakteristischen Gefässumbau (Remodelling) der kleinen pulmonalen Arterien aufgrund exzessiver Proliferation und Migration der pulmonalen glatten Muskel- und Endothelzellen. Trotz neuer Therapieansätze bleibt die PH eine nicht heilbare Erkrankung, insbesondere weil das Remodelling, welches die Irreversibilität und die Chronizität der Erkrankung definiert, bisher nicht therapeutisch adressiert werden konnte. Neue Erkenntnisse aus der Pathogenese des Gefässumbaus sind deshalb für die Entwicklung potentiell kausaler Therapieansätze von eminenter Wichtigkeit. Zustände von niedrigem Sauerstoffgehalt (Hypoxie) gehören zu den wichtigsten pathogenetischen Faktoren, welche eine pulmonale Hypertonie auslösen, sie bilden auch die Grundlage für das etablierte experimentelle Mausmodell der Hypoxie-induzierten pulmonalen Hypertonie. In diesem Kontext sind Aquaporine - eine Familie von 13 membranständigen Wasserkanälen in Säugetieren, die in unterschiedlichen Zelltypen und Organen, so auch z.B. der Lunge, vorkommen - wiederholt als interessante Faktoren beschrieben worden: sie, vor allem Aquaporin 1 (AQP1), regulieren zusätzlich verschiedene physiologische Prozesse wie Zellproliferation, Zellmigration, und Angiogenese, welche auch im Zusammenhang mit dem pulmonalen Gefässumbau eine Rolle spielen. Wie in Versuchen an Ratten und Zellkulturexperimenten in glatten Muskelzellen gezeigt wurde, wird die Expression von AQP1 zudem durch Hypoxie gesteuert und stabilisiert. AQP1 ist überdies von immenser Wichtigkeit im Zusammenhang von Hypoxie-induzierter Migration der glatten Muskelzellen. Basierend auf diesen Daten gehen wir von einer bisher unbeschriebenen, pathogenetischen Rolle von AQP1 beim Remodelling in der Hypoxie-induzierten pulmonalen Hypertonie aus, weil das Zusammenspiel zwischen AQP1, Hypoxie und PH noch nicht direkt adressiert wurde. Der Schwerpunkt meiner Doktorarbeit war die Erforschung der Expression und 
funktionellen Charakterisierung von AQP1 in Zellkulturexperimenten und im Mausmodell der Hypoxie-induzierten PH. Unserem Ansatz nach erwarten wir neue Erkenntnisse im Bereich der Pathogenese dieser Krankheit, welche später vielleicht zur Entwicklung neuer Therapieansätze führen könnte.

Mit meiner PhD Dissertation konnte ich aufzeigen, dass sich (i) die Expression von AQP1 in menschlichen pulmonalen Gefässzellen signifikant erhöhte, nachdem man diese Hypoxie ausgesetzt hat. Des Weiteren war die (ii) AQP1 Expression auch in Lungen von Mäusen mit Hypoxie-induzierter PH aufreguliert. Die funktionelle Rolle von AQP1 wurde zusätzlich in menschlichen pulmonalen glatten Muskelzellen (HPASMC) getestet. Mit diesen Experimenten konnte gezeigt werden, dass die (iii) Inhibierung von AQP1 durch neue antisense-orientierte DNA Moleküle (GapmeRs) die Proliferation und Migration gehemmt hat, zur selben Zeit jedoch die Apoptose gestiegen ist. Gegenteilige Resultate wurden erzielt, wenn (iv) AQP1 durch transiente Transfektion überexprimiert wurde: Proliferation und Migration von HPASMC waren erhöht. Bei Inhibition von AQP1 war dieser Effekt mit einer (v) hochregulierten Expression des Tumorsuppressorgens p53 verbunden. Um die physiologische Bedeutung von AQP1 für den Krankheitsverlauf der PH zu untersuchen, wurde das Mausmodell der Hypoxie-induzierten PH verwendet. Die (vi) Applikation von GapmeRs führte dabei zur Antagonisierung von AQP1 auf das Niveau normoxischer Kontrollmäuse. Physiologische Untersuchungen konnten dabei zeigen, dass sowohl die Erhöhung des rechtventrikulären Druckes als auch die für $\mathrm{PH}$ charakteristische rechtsventrikuläre Hypertrophie durch Inhibierung von AQP1 signifikant reduziert wurde.

Nach bestem Wissen wurde mit dieser Doktorarbeit zum ersten Mal der Zusammenhang zwischen AQP1 und PH aufgezeigt und beschrieben. Meine Daten untermauern die Hypothese, dass AQP1 eine entscheidende funktionelle Rolle in der Pathobiologie der Hypoxie-induzierten PH spielt. Da das Remodelling für therapeutische Ansätze bisher nicht zugänglich ist und auch die Unheilbarkeit der Erkrankung definiert, haben diese Resultate Auswirkungen sowohl für unser pathogenetisches Verständnis als auch potenziell neue Therapiemöglichkeiten. GapmeRs könnten einen neuen vielversprechenden Ansatz zur Behandlung von PH darstellen. 


\section{ACKNOWLEDGMENTS}

The implementation of my $\mathrm{PhD}$ project would not have been successful without the help and support of a number of people to whom I am deeply grateful:

Firstly, I would like to express my very great appreciation to my thesis supervisor Dr. Matthias Brock. His willingness to give his time so generously has been very much appreciated. I am particularly grateful for Matthias' guidance throughout the whole period of my project, which included his expert knowledge and opinion about molecular biology, abundance of patience, and providing assistance with the daily work in the laboratory. All in all, it was an intensive but very exciting time and I greatly valued the friendly atmosphere in the lab. Without Matthias it would have been impossible to complete this piece of research work.

Secondly, I would like to offer my thanks to Prof. Dr. med. Malcolm Kohler, head of the Department of Pulmonology at the University Hospital of Zurich, for giving me the opportunity to perform my doctorate at his well-equipped and modern laboratory in Schlieren.

Thirdly, I would also like to extent my thanks to Prof. Dr. med. vet. Max Gassmann, director of the Institute of Veterinary Physiology at the University of Zurich, who was my doctoral thesis supervisor. He always had an open ear when it came to difficulties or uncertainties, and always offered his help when needed. Furthermore, to PD Dr. med. Lars C. Huber, head of the Department of Internal Medicine at the Triemlispital Zurich, thank you very much for your overall expertise, support and assistance which contributed greatly to accomplish this thesis. I was able to learn a great deal from you, most notably in scientific writing and giving presentations.

Last but no least, I would further like to say thank you to all the members of the basic research group of the Department of Pulmonology: Dr. Thomas Rechsteiner, MSc Carlo Bühlmann, and Dr. Caroline Leuenberger. First and foremost Caro, you were a great "PhDTeammate" and thanks for your advice during my thesis, it helped a lot that you started a year 
ahead of me. All the things we did together outside the lab made the last three years a most enjoyable time.

Additionally, a warm and special thanks to my family and friends for showing understanding with my problems and worries regarding my $\mathrm{PhD}$ thesis. Successfully finishing my doctorate is also due to them.

Each and every one of above-mentioned persons made me a skilled and independent scientist, which will be very useful in the near future, wherever it may take me.

May 2017

Claudio Schuoler 


\section{INTRODUCTION}

\subsection{Pulmonary HyPertension}

Pulmonary hypertension (PH) is haemodynamically defined as an increase in mean pulmonary arterial pressure (mPAP) exceeding $25 \mathrm{mmHg}$ at rest or $30 \mathrm{mmHg}$ during physical activity. ${ }^{1,2}$ It was first described by Ernst von Romberg in $1891 .^{3}$ The sustained increase in blood pressure in the lung vasculature leads to exercise limitation and shortness of breath, fatigue, syncope, and, when left untreated, to right heart failure and death. ${ }^{4}$ Pulmonary arterial hypertension $(\mathrm{PAH})$, the most common form of $\mathrm{PH}$, is a rare disorder with an estimated incidence of approximately 2-3 cases per million per year. ${ }^{5}$

In 1973, the World Health Organization (WHO) prompted a first proposal on a clinical classification scheme for $\mathrm{PH}$ and ever since, the classification has gone through a series of changes, the most recent revision occurring during the $5^{\text {th }}$ World Symposium on Pulmonary Hypertension held in Nice, France, in 2013. ${ }^{6,7}$ Five groups of disorders that cause PH were identified (Group 1 to Group 5) (Table 1), which are based on clinical and pathobiological features, similar haemodynamic characteristics as well as similar therapeutic options.

Table 1. Clinical classification of pulmonary hypertension (PH) based on the $5^{\text {th }}$ World Symposium on Pulmonary Hypertension (Nice, France; 2013). Main modifications to the previous Dana Point classification (California, USA; 2008) are in bold. Reproduced from Simoneau et al. ${ }^{6}$

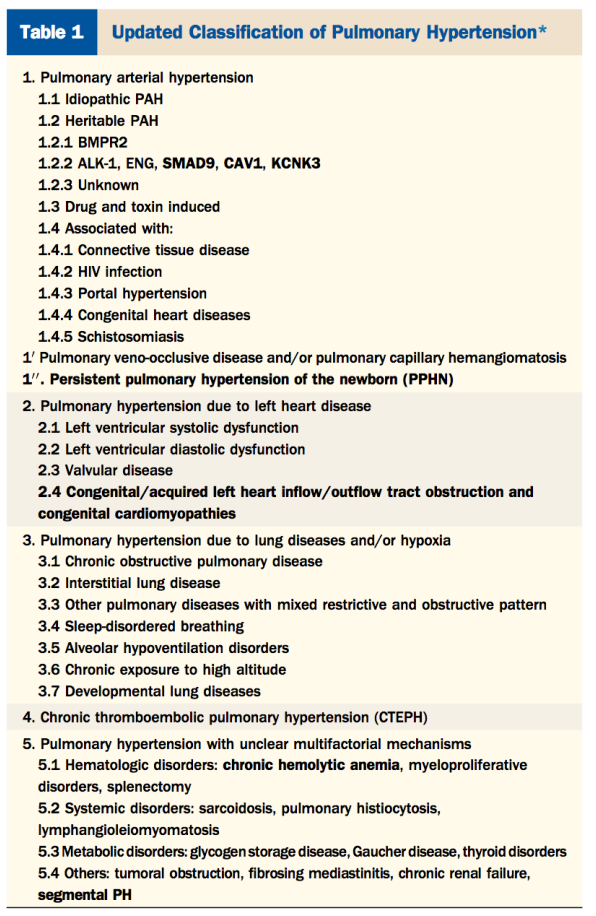


Although $\mathrm{PH}$ is a disease of various origins with a life-threatening outcome when left untreated, ${ }^{1,8}$ chronic hypoxia is considered a major trigger. ${ }^{9}$ Exposure to chronic hypoxia occurs not only in high-altitude residents but also in patients suffering from chronic diseases associated with reduced oxygen transport capacity during wakefulness and/or sleep such as congestive heart failure (CHF), chronic obstructive pulmonary disease (COPD), sleep apnoea (SA), and also cancer. ${ }^{10-13}$ Therefore, $\mathrm{PH}$ associated with hypoxia or chronic diseases of the respiratory system are regarded as separate entity and thus Group 3 of the Nice classification on $\mathrm{PH}$.

Whatever the initial cause and despite the fact that not all types of $\mathrm{PH}$ share a common aetiology, all five groups of $\mathrm{PH}$ are accurately defined by a progressive increase in pulmonary vascular resistance, caused by the triad of vasoconstriction, in situ micro-thrombosis and excessive vascular remodelling of the small pulmonary arteries. ${ }^{8,14,15}$ Endothelial cells (ECs) play a key role since a potential cause of the pathophysiological changes in PH most likely includes endothelial dysfunction leading to a homeostatic imbalance in the endotheliummediated secretion of vasoactive substances. ${ }^{16}$ A typical and frequently observed pattern in $\mathrm{PH}$ is that the release of vasoconstrictors and the expression of their receptors are upregulated whereas vasodilators are downregulated. In this context, the contraction of smooth muscle cells (SMCs) surrounding the small arteries is mainly associated with an increased expression of the vasoconstrictor endothelin-1 (ET-1) in the vasculature, whereas the release of the vasodilators nitric oxide (NO) and prostacyclin (e.g. prostaglandin $\mathrm{I}_{2}$ ) from ECs is reduced. ${ }^{14}$ Furthermore, reduced oxygenation regarding ECs also has an influence on their proliferation and migration, survival, expression of metabolites and inflammatory response. ${ }^{17,18}$ Whereas acute hypoxia increases pulmonary pressure by calcium-mediated vasoconstriction of pulmonary vascular SMCs on the short term, conditions of chronic hypoxia trigger mechanisms of remodelling that result in the development of irreversible $\mathrm{PH} .{ }^{19}$ Uncontrolled proliferation and resistance to apoptosis of these cells have also been described as neoplasticlike processes. ${ }^{20}$ Vascular remodelling is due to migration and proliferation of cells within all layers of the vessel wall, most prominently, however, of pulmonary artery SMCs and ECs, leading to a thickened and stiff vessel wall (Fig. 1). ${ }^{21}$ Additionally, narrowing of the arterial lumen can also be caused by coagulation of blood cells (microthrombosis). ${ }^{8}$ These processes influence the blood flow in the lungs, further raising the blood pressure and, during the progression of the disease, the increased workload of the heart results in right ventricular hypertrophy $(\mathrm{RVH}){ }^{22}$ To date, vascular remodelling is not satisfyingly addressed by treatment, as current treatment options only involve the vasoconstriction part. ${ }^{23}$ 


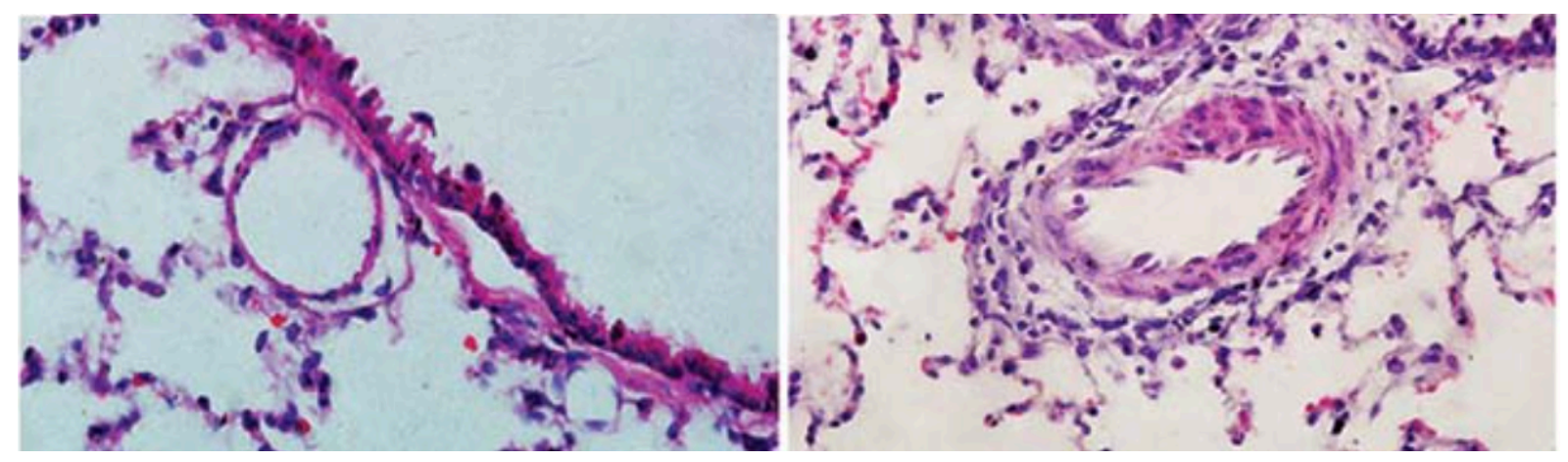

Figure 1. Pulmonary vascular remodelling in a rat model of PH. Compared to the control group (left), haematoxylin- and eosin-stained lung tissue from monocrotaline-treated rats shows hypertrophy of the artery within all cell layers (adventitia, media, and intima) due to vascular remodelling and aberrant vascular cell proliferation (right). Reproduced from Bai et al. ${ }^{24}$

The development of modern therapies significantly improved the life expectancy of patients suffering from PH. So far, three different classes of drugs are clinically approved for the treatment of $\mathrm{PH}$, which all are involved in a vasoactive dependent manner. ${ }^{22}$ Successfully employed strategies comprise of:

(i) Prostanoids (e.g. epoprostenol (Flolan), a synthetic analogue of prostacyclin) ${ }^{25}$

(ii) ET-1 receptor antagonist (e.g. Bosentan, Macitentan, and Ambrisentan) ${ }^{26}$

(iii) Phosphodiesterase-5 (PDE5) inhibitors (e.g. Sildenafil or Tadalafil) ${ }^{27}$

Prostacyclin, a prostanoid, is mainly produced by the endothelium and acts as a vasodilator, therefore widening the blood vessels via SMC relaxation. It has been shown that intravenously applied prostacyclin improved exercise capacity, haemodynamics, quality of life as well as survival of PH patients. ${ }^{28}$ Furthermore, ET-1 not only acts as a vasoconstrictor but also as a proliferative factor of SMC, therefore contributing to vascular remodelling in $\mathrm{PH}^{29,}{ }^{30}$ Blocking of ET-1 receptors by antagonists may counteract the pathophysiological condition seen in this disease. Moreover, inhibition of PDE-5 enzymes leads to intracellular cyclic guanosine monophosphate (cGMP) accumulation since PDE-5 is no longer able to degrade cGMP. As a result, the vasodilator NO will increase. ${ }^{31-33}$ A recent study has demonstrated that sildenafil given in combination with the blood hormone erythropoietin (Epo) showed an additive effect in survival and migration of hypoxic ECs. ${ }^{34}$ Additionally, the combination of sildenafil and Epo in vivo was able to effectively attenuate hypoxia-induced $\mathrm{PH}$ in mice. ${ }^{35}$ To summarize, all mentioned drugs above involve either a direct or indirect pathway leading to vasodilation, therefore possibly decreasing pulmonary vascular resistance. These agents, however, are often non-specific and face some serious drawbacks including 
short half-lives, higher dosing and frequency requirements, and several dose-related systemic side effects. $^{36}$

Despite the improvement in life quality, current therapies fail to cure $\mathrm{PH}$. This is probably due to the fact that they only target the imbalance between vasoconstrictors and-dilators, whereas the process of vascular remodelling still continues. Therefore, extensive research has been conducted in the last years in order to understand the molecular mechanisms leading to vascular remodelling in $\mathrm{PH}$. The ultimate goal is to reverse the process of pulmonary vascular remodelling, finally healing patients of their disease. In this context, dysregulated expression of bone morphogenetic protein receptor type II (BMPR2) is a pathogenetic hallmark and a common feature in the pathogenesis of $\mathrm{PH}$, responsible for approximately $70 \%$ of hereditary PAH and $20 \%$ of idiopathic $\mathrm{PAH}^{37}$ It has been shown in a novel pathway that cytokine interleukin-6 (IL-6) and the microRNA (miRNA) cluster miR-17/92 tightly control the expression of BMPR2 and therefore providing a novel mechanistic insight in the pathogenesis of pulmonary vascular remodelling. ${ }^{38}$ Long non-coding RNAs (lncRNA) are emerging as potential new players in the context of PH. For instance, metastasis-associated lung adenocarcinoma transcript 1 (MALAT1) is induced by hypoxia and depletion inhibited migration and proliferation of SMCs, potentially having implications for the pathogenetic understanding of the disease. ${ }^{39}$ Furthermore, one of the best characterized tumor suppressor genes is $\mathrm{p} 53^{40}$ and, in the context of PH, Jacquin et al. showed that p53 is found downregulated in the monocrotaline model of $\mathrm{PH}$. Moreover, inactivation of p53 alone was sufficient to induce the development of experimental $\mathrm{PH}^{41,42}$ Another study demonstrated that exogenous NO has an inhibitory effect on smooth muscle cell proliferation via induction of $\mathrm{p} 53$ and $\mathrm{p} 21 .{ }^{43}$

To conclude, treatment options are available but new therapeutic options are highly needed, since the disease is still incurable. Patients reveal a progressive clinical deterioration and their prognosis is in most cases rather poor. ${ }^{22}$ On these grounds, already a minor improvement in the clinical outcome would mean an enhancement in the quality of life of concerned patients.

\subsection{AQUAPORINS}

Water as a universal solvent is the major component of all living cells and its transport (water influx and efflux) needs to be regulated. It was long assumed that simple diffusion alone accounts for all water movement through biological membranes. The problem, however, was that diffusion does not provide an explanation for the rapid water movement across plasma membranes of cells. Therefore, scientists believed that there must be a specialized protein 


\subsection{Aquaporins}

channel responsible for the fast water transport, which has been described physically despite a lack of molecular understanding. ${ }^{44}$ It was not until 1986 in Romania when Gheorghe Benga and colleagues discovered the first water channel protein in the membrane of erythrocytes. ${ }^{45}$, ${ }^{46}$ The same protein was purified by serendipity by Peter Agre group in 1987 in Baltimore. ${ }^{47}$ Further studies indicated that the newly discovered protein was surprisingly abundant and could facilitate rapid and selective water movement in the direction of an osmotic gradient. ${ }^{48}$ Hence, the temporary name channel-like integral membrane protein $28 \mathrm{kDa}$ (CHIP28) was introduced firstly, ${ }^{49}$ and then replaced by the term aquaporin (AQP) which applies in this form until today. ${ }^{50}$ In contrast to simple diffusion alone, where water moves bidirectional in a low-capacity manner, the newly discovered AQPs have a high capacity, and great selectivity and permeability to water. Despite the two landmark publications from Benga group, ${ }^{45,46}$ the Nobel Prize in Chemistry was awarded "for discoveries concerning channels in cell membranes" only to Peter Agre "for the discovery of water channel" in 2003, which aroused some controversies in the scientific community. ${ }^{51}$

AQPs belong to a group of highly conserved membrane proteins that can be found ubiquitously in virtually all-living organisms. ${ }^{52}$ Their occurrence in the five kingdoms of life (animals, plants, fungi, eubacteria, and archaea) indicates a high preservation of the gene family over time. In mammals, 13 isoforms (AQP0-AQP12) were identified which are widely distributed in specific cell types in many organs and tissues including the lungs. ${ }^{53}$ With the completion of the human genome project in 2003, more members will not likely be identified.

Table 2. Mammalian aquaporins (AQP0-AQP12) and their permeability and tissue localization. Classical aquaporins (pale blue) are defined as channels highly selective for water, whereas aquaglyceroporins (blue) refer to the additional passage of glycerol and urea, along with water. Superaquaporins are depicted in dark blue (AQP11 \& AQP12). Adopted from Kreida et al. \& King et al. ${ }^{54,55}$

\begin{tabular}{|l|l|l|}
\hline Aquaporin & Selectivity & Localization \\
\hline AQP0 & Water & Eye lens \\
\hline AQP1 & Water & Red blood cells, kidney, blood vessel, lung, brain, eye \\
\hline AQP2 & Water & Kidney (collecting duct) \\
\hline AQP3 & Water, glycerol, urea & Kidney, skin, intestine, eye, lung \\
\hline AQP4 & Water & $\begin{array}{l}\text { Brain, kidney, muscle, lung, gastro-intestinal tract, } \\
\text { eye, airways }\end{array}$ \\
\hline AQP5 & Water & $\begin{array}{l}\text { Lung, airways, cornea, pancreas, salivary and sweat } \\
\text { glands }\end{array}$ \\
\hline AQP6 & Water & Kidney \\
\hline AQP7 & Water, glycerol, urea & Adipose tissue, kidney, liver, testis, heart muscle \\
\hline AQP8 & Water & Gastro-intestinal tract, kidney, liver, testis \\
\hline AQP9 & Water, glycerol, urea & Liver, brain, testis, leukocytes \\
\hline AQP10 & Water, glycerol, urea & Small intestines \\
\hline AQP11 & Water & Liver, testis, kidney \\
\hline AQP12 & Unknown & Pancreas \\
\hline
\end{tabular}


Each type differs mainly in its tissue distribution and permeability characteristics and can therefore be divided into three subsets based on the primary sequence: (i) classical aquaporins, considered to be water selective, (ii) aquaglyceroporins, permeable to glycerol and other small solutes (e.g. urea) in addition to water, and (iii) superaquaporins, whose specific function, apart from water transport, remains to be clarified (Table 2). ${ }^{56,57}$

AQPs belong to the family of transmembrane proteins, more precisely to small integral membrane proteins, therefore permanently attached to the plasma membrane. The different AQPs subsets deviate in their peptide sequence, thus showing different pore sizes. The monomeric units of AQP1 are about $28 \mathrm{kDa}$, depending on glycosylation and phosphorylation, and appears as a homotetramer where each monomer consists of six membrane-spanning $\alpha$-helices (M1, M2, M4-M6 and M8), two half-helices (M3 and M7) and five connecting loops (a-e), forming an hourglass-shaped structure, where both the amino and carboxyl terminus are located in the cytoplasm (Fig. 2a). ${ }^{52,58-60}$ Two structures within the channel account for the selective passage of water: (i) the highly conserved three residue motif asparagine-proline-alanine (NPA) in loops $b$ and $e$ and (ii) the so called aromatic/arginine ( $\mathrm{ar} / \mathrm{R})$ constriction region (Fig. 2b). The former is responsible that upon
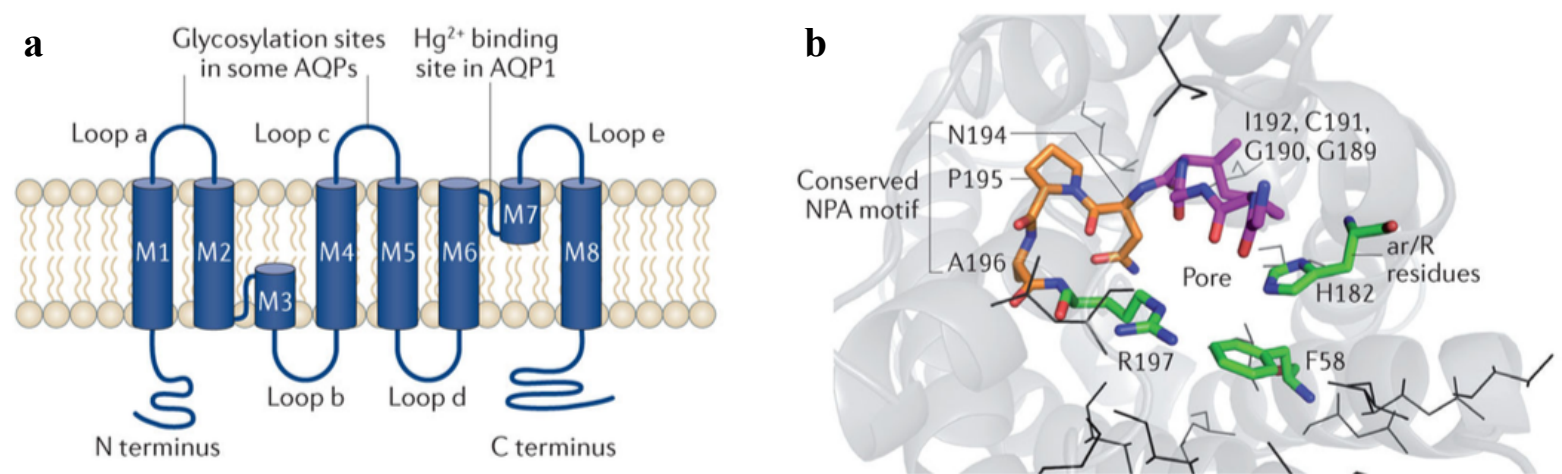

Figure 2. Membrane topology of aquaporin 1 (AQP1). a Schematic of the AQP1 monomer consisting of six transmembrane $\alpha$-helices (M1, M2, M4-M6 \& M8), two half-helices (M3 \& M7) and five connecting loops (ae). b Extracellular vestibule of AQP1 with conserved NPA motif (orange) and ar/R constriction region (green) accounting for proton exclusion and selective transit of water molecules. Reproduced from Verkman et al. ${ }^{60}$

entering, a rotation of water molecules occurs caused by hydrogen bonds between the oxygen atom of the water molecule and the asparagines in the two NPA motifs, a possible cause to prevent protons from crossing the pores. ${ }^{61,62}$ The latter ar/R constriction site refers to the narrow pore region, formed by arginine, histidine, phenylalanine, and cysteine. ${ }^{63}$ It has been shown that cysteine is the blockage site of AQP1 by mercury chloride $\left(\mathrm{HgCl}_{2}\right.$, see further below), which is thought to sterically occlude the water pore. ${ }^{64,} 65$ The two amino acids arginine and histidine provide positive charges to further repel proton passage, while 


\subsection{Aquaporins}

permitting rapid transport of single water molecules through the narrow pore. ${ }^{66}$ In conclusion, both mechanisms exhibit electrostatic barriers accounting for proton exclusion and the selective transit of water molecules.

AQPs can be found throughout the body and are differentially expressed in organs and tissues involved in fluid absorption or secretion, such as epithelial cells, but also in non-fluid transporting tissues like brain, skin, fat, and liver (Fig. 3). It has been shown that AQPs are additionally involved in various physiological functions including trans-epithelial fluid transport, cell migration (e.g. wound healing, tumour metastasis, and glial scar formation), cell proliferation, angiogenesis, brain water regulation, adipocyte metabolism, and neuroexcitation. ${ }^{60}$ These processes are, probably by the action of AQPs, of major importance for the physiological adaption to hypoxia as well as in the pathophysiology of cancer and hypoxia-related diseases. ${ }^{67-69}$

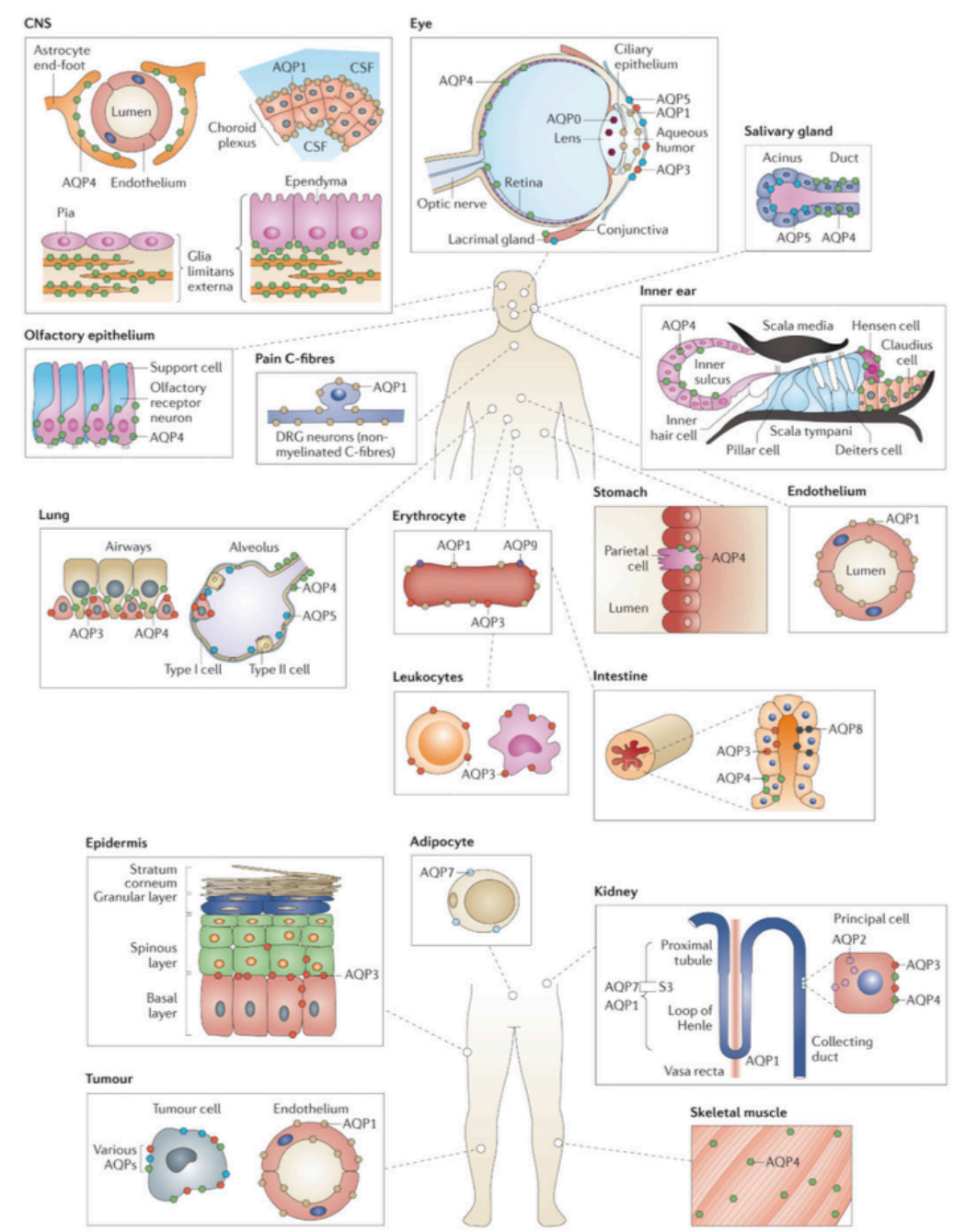

Figure 3. Tissue distribution of mammalian aquaporins (AQPs). AQPs are widely expressed in the body, particularly in cell types involved in fluid transport, such as epithelial cells in several organs, as well as in some cell types that do not have an obvious role in fluid transport, such as adipocytes. Of importance, AQP1 is expressed in the endothelium and in smooth muscle cells (not shown). Reproduced from Verkman et al. ${ }^{60}$ 
A steadily growing number of studies emphasize that AQPs seem to be strongly involved in stress-induced tissue transformation processes. Recently, it was suggested that hypoxia modulates AQP1 expression in different organs, e.g. mouse lungs. ${ }^{70}$ Moreover, in rat pulmonary artery smooth muscle cells, hypoxia selectively increased AQP1 protein levels and, in turn, migration of these cells. Silencing of AQP1 via siRNA prevented the hypoxiainduced migration. ${ }^{71}$ Furthermore, a study investigated the role of the C-terminal tail of AQP1 on migration and proliferation, because the exact mechanism by which AQP1 facilitates these two processes was unknown. ${ }^{72}$ In this setting, the C-terminus was required since its deletion in AQP1 overexpressing rat smooth muscle cells abolished the effect on both migration and proliferation. The authors concluded that the possible AQP1-mediated mechanisms include association of factors or proteins with the C-terminal tail, however, without offering an explanation how AQP1 executes its function in this context. A proposed model of AQP1mediated migration was prompted by Saadoun et al., where AQP1 expression polarizes to the leading edge of lamellipodia extension, facilitating water influx and cell migration, therefore hypothesizing a possible connection between AQP1 and the cytoskeleton. ${ }^{73}$

In addition, enhanced p53 expression levels were found after silencing of AQP3 with shRNA in a non-small cell lung cancer (NSCLC) model, which was accompanied with suppressed tumour proliferation. ${ }^{74}$ AQP3 knockdown reduced cellular glycerol content (AQP3 is an aquaglyceroporin) and mitochondrial ATP formation, which, together with reduced expression of the proliferation marker proliferating cell nuclear antigen (PCNA), might contribute to the inhibitive effect on tumour proliferation. Of note, the importance of AQP1 for the vascular smooth muscle phenotype was highlighted in a study by Al Ghouleh et al. demonstrating that reactive oxygen species are channelled via AQP1 resulting in hypertrophy, however, without affecting proliferation. ${ }^{75}$ Moreover, microarray data further revealed alterations in several proliferation-regulating genes suggesting that AQP1 modifies the expression of key cell cycle proteins. ${ }^{76}$ All these data suggest a possible link between the excessive vascular remodelling observed in patients with $\mathrm{PH}$ and both expression and function of AQP1.

Surprisingly, there is a lack of verified pharmacological inhibitors for AQPs, but studies of the phenotype of AQP-knockout mice have provided most of the information on AQP physiology. Compelling evidence from studies using AQP-knockout mice and from humans with AQPs loss-of-function mutations suggest AQPs as drug targets, having broad clinical indications in nephrology, neurology, oncology, and ophthalmology. The identification of AQP modulators, however, has turned out to be unexpectedly challenging and the poor 


\subsection{Aquaporins}

drugability of AQPs may be, among others, due to the small size of the functional AQP monomer and its very small pore diameter, which prevents the access of small molecules. ${ }^{60}$ There has been extensive research on the identification of AQP inhibitors, but no study found any suitable candidate, even when tested $1^{\prime} 000{ }^{\prime} 000$ compounds in a virtual screen. ${ }^{77}$ There is one exception: $\mathrm{HgCl}_{2}$ has been widely used as an inhibitor of $\mathrm{AQP1}$ and is thought to sterically occlude the water pore. ${ }^{64,}{ }^{65}$ However, $\mathrm{HgCl}_{2}$ is a nonspecific inhibitor and potentially very toxic if given in high doses, therefore unsuitable for in vivo use. To overcome the poor drugability of the AQP1 protein, inhibition of AQP1 mRNA by antisense oligonucleotides (ASO) strategy could offer an attractive alternative. The so-called GapmeRs are short single-stranded antisense oligonucleotides modified with locked nucleic acids (LNA) in the flanking regions and DNA in a central gap (hence the name) to ensure enhanced stability and high affinity and were proven to repress gene expression in mice and non-human primates. $^{78}$ Application of GapmeRs directed against AQP1, for instance, would result in RNase H-dependent degradation of complementary AQP1 RNA, both in vitro and in vivo. GapmeR inhibitors show high binding-efficacy, stability and a good bio-distribution whereas activation of the innate immune system (a common unwanted effect for RNA interference approaches) is unlikely. This makes GapmeRs an attractive therapeutic tool that might be very well tolerated by the recipient. The use of these novel antisense oligonucleotides could be limited by non-specific binding to proteins and off-target effects such as hepatotoxicity. ${ }^{79}$ Consequently, researchers are very interested in finding new nontoxic alternatives being selective for AQPs, having implications in clinical therapies and the treatment of human diseases. $^{80}$

\subsection{OBJECTIVES}

On the grounds of the above-mentioned introduction, the aim of my $\mathrm{PhD}$ thesis was to examine the involvement of AQP1 as a potential key player in the development of hypoxiainduced $\mathrm{PH}$, whose pathogenesis is characterized by vascular remodelling and vasoconstriction. To the best of our knowledge, however, little is known about the interaction between AQP1, hypoxia, and PH and the role of AQP1 in the pathobiology of vascular remodelling in $\mathrm{PH}$ has not been directly addressed so far. Although the mechanism of action remains poorly understood, it has been shown in several studies that upon hypoxia, the expression of AQP1 is increased. ${ }^{70,71}$ As AQP1 is the best described of all AQPs and additionally expressed in pulmonary vascular SMCs and ECs, the present study was designed 
to investigate the expression and function of AQP1 in vitro in human vascular cells derived from pulmonary arteries and in vivo in the mouse model of hypoxia-induced PH. In detail, the functional consequence of altered AQP1 expression in human vascular cells (human pulmonary vascular smooth muscle (HPASMC) and endothelial cells (HPAEC), respectively) was assessed with an emphasis on migration, proliferation and resistance to apoptosis. Manipulation of AQP1 expression was achieved using GapmeRs for silencing experiments and an overexpression vector to induce AQP1 levels. The physiological consequences of AQP1 depletion via intraperitoneal (i.p.) GapmeR injections on haemodynamics were further addressed in vivo by employing the hypoxia-induced mouse model of PH. Elaborately, the focus was set on measuring right ventricular pressure (RVP) and RVH. In the following chapter 2 'Aquaporin 1 controls the functional phenotype of pulmonary smooth muscle cells in hypoxia-induced pulmonary hypertension' of this $\mathrm{PhD}$ thesis, the data on the role of AQP1 function and expression in the context of hypoxia-induced $\mathrm{PH}$ are presented.

Thus, the following working hypotheses have been defined:

- Hypoxia can modulate the expression of AQP1, which is important for the progression and pathogenesis of $\mathrm{PH}$.

- AQP1 contributes to hypoxia-induced tissue remodelling. 


\title{
2 Aquaporin 1 Controls the Functional Pheno- type of Pulmonary Smooth Muscle Cells in Hypoxia-InduCEd Pulmonary HyPERTENSION
}

\section{Aquaporin 1 controls the functional phenotype of pulmonary smooth muscle cells in hypoxia-induced pulmonary hypertension}

\author{
Claudio Schuoler ${ }^{1,2,3}$ - Thomas J. Haider ${ }^{1,2}$ - Caroline Leuenberger ${ }^{2,3}$. \\ ${\text { Johannes } \text { Vogel }^{1} \text { - Louise Ostergaard }}^{1,2}$ - Grazyna Kwapiszewska ${ }^{4}$. \\ Malcolm Kohler ${ }^{2,3} \cdot$ Max Gassmann $^{1,2} \cdot$ Lars C. Huber ${ }^{3}$. Matthias Brock ${ }^{3}$
}

Received: 8 December 2016/Accepted: 7 April 2017

(C) Springer-Verlag Berlin Heidelberg 2017

Claudio Schuoler and Thomas J. Haider share first authorship.

Lars C. Huber and Matthias Brock share senior authorship.

Electronic supplementary material The online version of this article (doi:10.1007/s00395-017-0620-7) contains supplementary material, which is available to authorized users.

Matthias Brock

matthias.brock@uzh.ch

1 Institute of Veterinary Physiology, Vetsuisse Faculty, University of Zurich, Zurich, Switzerland

2 Zurich Center for Integrative Human Physiology (ZIHP), University of Zurich, Zurich, Switzerland

3 Division of Pulmonology, University Hospital Zurich, University of Zurich, Zurich, Switzerland

4 Ludwig Boltzmann Institute for Lung Vascular Research, Graz, Austria

Published online: 13 April 2017
Keywords Aquaporin 1 - Pulmonary hypertension · Hypoxia · Proliferation · Vascular remodelling

Published in: Basic Research in Cardiology (Impact Factor 2015: 6.038) 


\subsection{ABSTRACT}

Vascular remodelling in hypoxia-induced pulmonary hypertension (PH) is driven by excessive proliferation and migration of endothelial and smooth muscle cells. The expression of aquaporin 1 (AQP1), an integral membrane water channel protein involved in the control of these processes, is tightly regulated by oxygen levels. The role of AQP1 in the pathogenesis of $\mathrm{PH}$, however, has not been directly addressed so far. This study was designed to characterize expression and function of AQP1 in pulmonary vascular cells from human arteries and in the mouse model of hypoxia-induced PH. Exposure of human pulmonary vascular cells to hypoxia significantly induced the expression of AQP1. Similarly, levels of AQP1 were found to be upregulated in lungs of mice with hypoxia-induced PH. The functional role of AQP1 was further tested in human pulmonary artery smooth muscle cells demonstrating that depletion of AQP1 reduced proliferation, the migratory potential, and, conversely, increased apoptosis of these cells. This effect was associated with higher expression of the tumour suppressor gene p53. Using the mouse model of hypoxia-induced PH, application of GapmeR inhibitors targeting AQP1 abated the hypoxia-induced upregulation of AQP1 and, of note, reversed PH by decreasing both right ventricular pressure and hypertrophy back to the levels of control mice. Our data suggest an important functional role of AQP1 in the pathobiology of hypoxia-induced PH. These results offer novel insights in our pathogenetic understanding of the disease and propose AQP1 as potential therapeutic in vivo target.

\subsection{INTRODUCTION}

Pulmonary hypertension (PH) is the pathophysiological consequence of several diseases and is, in many cases, triggered or aggravated by hypoxia $[26,28,30]$. The pulmonary vasculature of $\mathrm{PH}$ patients is characterized by vasoconstriction, microthrombotic events, and excessive remodelling of the small pulmonary arteries [9, 24]. Whereas acute hypoxia increases pulmonary pressure by calcium-mediated vasoconstriction of pulmonary vascular smooth muscle cells on the short term, conditions of chronic hypoxia, including many parenchymal lung diseases, trigger mechanisms of remodelling that result in the development of irreversible pulmonary hypertension [37]. Vascular remodelling is due to migration and proliferation of cells within all layers of the vessel wall, most prominently, however, of pulmonary artery smooth muscle and endothelial cells [20]. Uncontrolled proliferation and 


\subsection{Introduction}

resistance to apoptosis of these cells have also been described as neoplastic-like processes [29]. To date, vascular remodelling is not satisfyingly addressed by treatment [7].

The mammalian aquaporins (AQPs) are a class of water channels that regulate the rapid water movement across the plasma membrane in response to an osmotic gradient [18]. The AQP family consists of 13 different subsets (AQP0-12) so far which are expressed in multiple organs including the lungs. AQPs are involved in various physiological processes such as trans-epithelial fluid transport, cell migration, cell proliferation, and angiogenesis [35]. These processes are, probably by the action of AQPs, of major importance for the physiological adaption to hypoxia as well as in the pathophysiology of cancer [34] and hypoxia-related diseases [27].

A steadily growing number of studies emphasize that AQPs seem to be strongly involved in stress-induced tissue transformation processes. Recently, it was suggested that hypoxia modulates AQP1 expression in different organs, e.g. mouse lungs [1]. Moreover, in rat pulmonary artery smooth muscle cells, hypoxia selectively increased AQP1 protein levels and, in turn, migration of these cells [14]. These data suggest a possible link between the excessive vascular remodelling observed in patients with $\mathrm{PH}$ and both expression and function of AQP1.

However, the role of AQP1 in the pathobiology of vascular remodelling in PH has not been directly addressed so far. The present study was designed to investigate the expression and function of AQP1 in human vascular cells derived from pulmonary arteries and in the mouse model of hypoxia-induced PH. In detail, the functional consequence of altered AQP1 expression in human vascular cells was assessed with an emphasis on migration, proliferation and resistance to apoptosis. The physiological consequences of AQP1 depletion on haemodynamics were further addressed in vivo by employing the hypoxia-induced mouse model of PH.

\subsection{METHODS}

\section{Animal experiments}

Male mice (C57BL/6, aged 12 weeks) were obtained from Charles River (Sulzfeld, Germany) and used for the hypoxia-induced PH mouse model as previously described in our publications [3, 4]. Briefly, the animals were randomized into a normoxic control group $(n=$ 8, room air, $\left.21 \% \mathrm{O}_{2}\right)$ and a hypoxic group $\left(n=8,10 \% \mathrm{O}_{2}\right)$. Normobaric hypoxic condition 
was provided in a sealed glove-chamber connected to a gas mixer (Coy Laboratory Products, Grass Lake, MI, USA). Mice were assessed daily for activity and wellbeing. All animals had access to standard diet and tap water ad libitum. At day 35, after 5 weeks of hypoxic exposure, mice were anaesthetized (induction, 5\% isoflurane; maintenance, 1.5-2\% isoflurane and $100 \% \mathrm{O}_{2}$ ) and systemic arterial pressure (SAP) was measured in the isolated femoral artery. Next, right ventricular pressure (RVP) was evaluated as an endpoint measurement of $\mathrm{PH}$, performed by right heart catheterization as previously described [10]. Mice were subsequently euthanized by cervical dislocation and lungs were collected for further analysis.

For treatment experiments, an additional mouse experiment was employed. Mice were divided into treatment and control groups (four groups of $n=8$ each). After 3 weeks of hypoxic exposure $\left(10 \% \mathrm{O}_{2}\right)$, the hypoxic mice were randomly assigned to three different groups to be further kept untreated or treated every 4 days by intraperitoneal (i.p.) injections with antisense oligonucleotides (GapmeRs) directed against AQP1 or GapmeR scrambled negative control $(10 \mathrm{mg} / \mathrm{kg}$ solved in sterile $0.9 \% \mathrm{NaCl})$. GapmeRs are short oligonucleotides modified with locked nucleic acids (LNA) in the flanking regions and DNA in a central gap (hence the name GapmeR). Application of GapmeR AQP1 results in RNase H-dependent degradation of complementary AQP1 RNA.

One mouse (hypoxic GapmeR negative control) died during the course of the experiment. Two weeks later, mice were analysed for RVP. The RVP of two hypoxic GapmeR AQP1 mice could not be measured, since these mice died during right heart catheterization. Afterwards, animals were euthanized and lungs were harvested. To assess right ventricular hypertrophy, the ratio between right ventricular and left ventricular diameter including interventricular septum $[\mathrm{RV} /(\mathrm{LV}+\mathrm{S})]$ was calculated based on the average of three linear diameter measurements across each heart section. All animal experiments were approved by the Cantonal Veterinary Office Zurich (approval numbers 151/2012 and 212/2014) and performed according to the guidelines from Directive 2010/63/EU of the European Parliament.

\section{Cell culture}

Human pulmonary artery smooth muscle (HPASMC) (ScienCell, Carlsbad, CA, USA; donor $\# 1$ and \#2) and human pulmonary artery endothelial cells (HPAEC) (ScienCell, Carlsbad, CA, USA; donor \#1, and PromoCell, Heidelberg, Germany; donor \#2) derived from two healthy donors were expanded in cultures according to the manufacturer's instructions. Cells were incubated in a humidified atmosphere at $37{ }^{\circ} \mathrm{C}$ and $5 \% \mathrm{CO}_{2}$. In all experiments, one batch of 


\subsection{Methods}

cells with passage number between two and eight was used. Cells were seeded and allowed to settle for at least $12 \mathrm{~h}$ before being transfected or exposed to hypoxia. Hypoxic experiments $\left(1 \% \mathrm{O}_{2}\right)$ were carried out over different time points (e.g. functional assays for $48 \mathrm{~h}$ ) in an $\mathrm{O}_{2}$ adjustable incubator (Binder, Tutlingen, Germany) maintained at $37{ }^{\circ} \mathrm{C}$ with $5 \% \mathrm{CO}_{2}$.

\section{Transient transfection of primary cultured cells}

For manipulation of endogenous levels of AQP1, HPASMC were transfected with GapmeR targeting AQP1 or GapmeR negative control (25 nmol/L) using Lipofectamine 2000 transfection reagent (Life Technologies, Zug, Switzerland) according to the manufacturer's protocol. Cell culture grade GapmeR inhibitors were obtained from Exiqon (Vedbaek, Denmark) and their sequences are listed in Supplementary Table 1. Following an incubation period of 24 or $48 \mathrm{~h}$, cells were either harvested for gene expression analysis or prepared for functional assays.

\section{Plasmid construction and overexpression}

The conventional PCR was used to amplify the coding sequence of AQP1 (809 bp) out of cDNA from HPASMC. The obtained PCR product was digested with HindIII and XhoI and subsequently cloned into pcDNA 3.1(+) vector (Invitrogen, Basel, Switzerland). Successful insertion of AQP1 was confirmed by Sanger sequencing (Microsynth, Balgach, Switzerland). Primers used for cloning are provided in Supplementary Table 2. To overexpress AQP1, HPASMC were transfected either with $0.25 \mu \mathrm{g}$ pcDNA_AQP1 or its corresponding empty vector, which served as a negative control, using electroporation technique (Amaxa Nucleofactor kit, Lonza, Basel, Switzerland). Subsequently, after 48 h, cells were harvested and gene overexpression was analysed by western blotting or cells were prepared for migration and proliferation assays.

\section{Quantitative real-time PCR (qPCR) analysis}

Total RNA of cultured cells or murine lung tissue samples were purified using the QuickRNA MiniPrep kit (Zymo Research, Freiburg im Breisgau, Germany) or the miRNeasy Mini kit (Qiagen, Hombrechtikon, Switzerland), respectively. Quality of isolated RNA was assessed by spectrophotometric analysis (Nanodrop, Wilmington, DE, USA). Isolated RNA was reverse-transcribed using random hexamers and GoScript reverse transcriptase (both from Promega, Dübendorf, Switzerland). Quantification of specific gene transcripts was 
performed by SYBR Green qPCR (Applied Biosystem StepOnePlus system, Life Technologies). To avoid amplification of genomic DNA, primers were designed to span an exon-exon junction. Sequences of primers used for gene expression analysis are listed in Supplementary Table 2. Specific amplification was verified performing melt curve analysis. Obtained expression levels of genes of interest were normalized to the expression of $\beta$-actin. Differential gene expression was calculated using the threshold cycle $\left(\mathrm{C}_{t}\right)$ method [25].

\section{Western blotting}

For protein extraction, harvested cells and murine lung tissue samples were lysed or homogenized using sample loading buffer $(62.5 \mathrm{mM}$ Tris- $\mathrm{HCl}, \mathrm{pH}$ 6.8, 2\% sodium dodecyl sulphate (SDS), 10\% glycerol, $5 \mathrm{mM} \beta$-mercaptoethanol, bromophenol blue). Whole-cell lysates (30 $\mu \mathrm{g}$ of protein) were separated by $12 \%$ sodium dodecyl sulphate polyacrylamide gel electrophoresis (SDS-PAGE) and proteins were transferred by electroblotting to a nitrocellulose membrane (Whatman, GE Healthcare Life Sciences, Little Chalfont, UK). Membranes were blocked with 5\% dry milk in Tris-buffered saline containing $0.1 \%$ Tween 20 (TBS-T) and incubated over night at $4{ }^{\circ} \mathrm{C}$ with the following primary antibodies: antiAQP1 (rabbit monoclonal, \#ab168387, Abcam, Cambridge, UK), anti-hypoxia-inducible factor 1 alpha (HIF-1 $\alpha$ ) (rabbit polyclonal, \#NB100-479, Novus Biologicals, Littleton, CO, USA), anti-p53 (mouse monoclonal, \#sc-126, Santa Cruz Biotechnology, Dallas, TX, USA), and anti- $\beta$-actin (mouse monoclonal, \#A2228, Sigma-Aldrich, Buchs SG, Switzerland), respectively. $\beta$-actin was used as a housekeeping protein for normalization. Bands were detected using species-specific secondary anti-bodies conjugated to horseradish peroxidase (Dako Agilent Technologies, Glostrup, Denmark). Calculation of the expression of proteins was performed using Adobe Photoshop CS5.1 software (Adobe Systems Incorporated, San Jose, CA, USA) via pixel quantification of the electronic image.

\section{Migration assay}

Migration of HPASMC was addressed according to a modified in vitro wound-healing assay. Briefly, 30’000 cells were seeded on each side of an Ibidi culture insert $\mu$-dish (Ibidi, Munich, Germany) for live cell analysis and transfected with GapmeR targeting AQP1 or scrambled negative control as described above. In addition, HPASMC were transfected with AQP1 overexpressing vector (pcDNA_AQP1) as stated above. Cells were allowed to grow to confluence for $24 \mathrm{~h}$ and afterwards, inserts were removed with sterile tweezers to create a 


\subsection{Methods}

cell-free gap of approximately $500 \mu \mathrm{m}$ width. The closure of the wound by migrating cells was quantitatively assessed at various time points after being photographed at $4 \mathrm{x}$ magnification under an inverted microscope (Olympus CKX41) as previously described [21]. The area of the initial wound was compared to the area of the healing wound at three different time points $(3,5$, and $7 \mathrm{~h})$.

\section{Proliferation and apoptosis assay}

To assess the proliferation rate, HPASMC were seeded in a 96-well plate at a density of 5000 cells per well and transfected with GapmeR targeting AQP1 or scrambled negative control as described above. For AQP1 overexpression, 10’000 cells were used and transfected either with pcDNA_AQP1 or its corresponding empty vector as mentioned above. After $24 \mathrm{~h}$, 5bromo-2-deoxyuridine (BrdU) was added to each well and cells were incubated for an additional $24 \mathrm{~h}$. Incorporation of BrdU was detected using the colorimetric BrdU assay from Roche (Roche Diagnostics, Mannheim, Germany). To assess apoptosis, HPASMC were seeded in a 96-well plate at a density of 10'000 cells per well and transfected with GapmeR targeting AQP1 or scrambled negative control. After $48 \mathrm{~h}$, apoptosis was evaluated in unstimulated cells (spontaneous apoptosis) by measuring the activity of caspase 3 and 7 (Caspase-Glo 3/7 assay, Promega, Dübendorf, Switzerland) according to the manufacturer's protocol.

\section{Statistics}

All data are presented as mean \pm standard deviation (SD). Parametric or non-parametric distribution of data was determined using the Kolmogorov-Smirnov test. Data comparison was performed using independent Student's $t$ test as well as Pearson's correlation for parametric samples. For comparing more than two sample groups, the one-way analysis of variance (ANOVA) with Tukey post hoc test for parametric samples and the Kruskal-Wallis test with Dunn's post hoc test for non-parametric samples was used. Paired Student's $t$ test or repeated-measures ANOVA was used with Tukey post hoc test to analyse functional assays and AQP1 gene expression levels (paired observations of the same subject). In all statistical analyses, two-sided tests were applied. Values of $\mathrm{p}<0.05$ were considered to be statistically significant $(* p<0.05, * * p<0.01, * * * p<0.001)$. The $n$ number indicates independent experiments. All statistical calculations were performed using the software package GraphPad Prism Version 5.0a (GraphPad Software, San Diego, CA, USA). 


\subsection{RESUlTS}

\section{AQP1 expression is increased in the mouse model of hypoxia-induced PH}

The regulation of AQP1 by hypoxia was characterized in lung samples of the mouse model of hypoxia-induced PH. As presented in Fig. 1a, mice exposed to chronic hypoxia showed a significant elevation in RVP compared to normoxic control mice (in mmHg: hypoxic mice $45.45 \pm 3.63$ vs. normoxic mice $30.83 \pm 2.60, p<0.001)$ indicating a successful in vivo application of the hypoxia-induced $\mathrm{PH}$ model. In lung tissue obtained from these mice, mRNA levels of AQP1 were significantly upregulated after hypoxia compared to normoxic control animals (by $1.31 \pm 0.14$ fold change, $p<0.01$; Fig. 1b). These data were confirmed on protein level by Western blotting. AQP1 protein levels were significantly increased after exposure to chronic hypoxia (by $1.92 \pm 0.70$ fold change, $p<0.01$; Fig. 1c). Since the levels of AQP1 were significantly upregulated under hypoxic conditions, a correlation analysis was performed showing a significant positive correlation of AQP1 protein levels with the RVP of experimental animals $(\mathrm{r}=0.636, p<0.01$; Fig. 1d $)$.

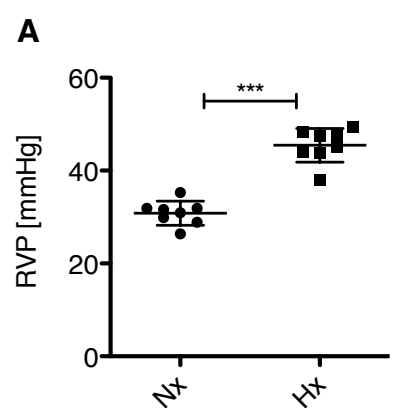

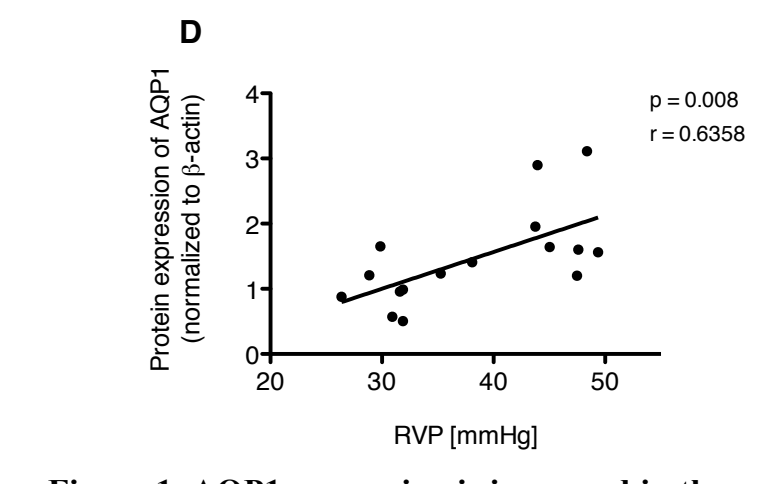
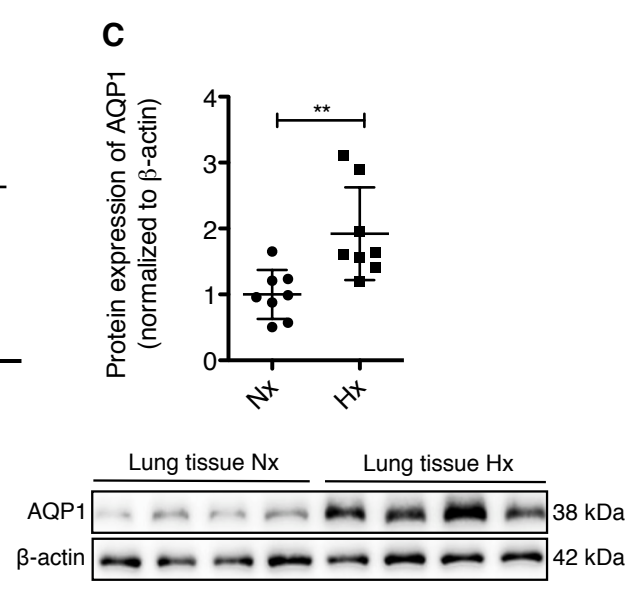

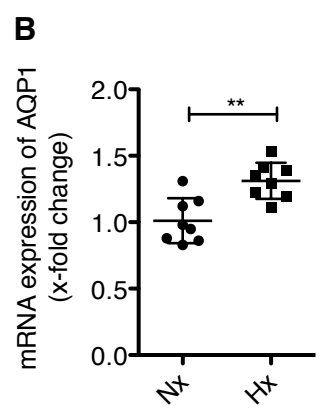

Figure 1. AQP1 expression is increased in the mouse model of hypoxia-induced PH. Mice were exposed to $10 \% \mathrm{O}_{2}$ for 5 weeks or kept under normoxia as controls. (a) Right ventricular pressure ( $\mathrm{RVP}$, in $\mathrm{mmHg}$ ) measured by right heart catheterization in normoxic $(\mathrm{Nx})$ and hypoxic $(\mathrm{Hx})$ mice. Effect of hypoxia on mRNA (b) and protein (c) levels of AQP1 from lung homogenates measured by qPCR and western blot compared to normoxic animals. A representative blot is provided $(30 \mu \mathrm{g})$. (d) Correlation analysis of AQP1 protein expression with RVP of the corresponding mouse. $n=8$ mice per group. Statistical analysis by unpaired Student's $t$ test $(\mathbf{a}-\mathbf{c})$ and Pearson's correlation $(\mathbf{d})(* * p<0.01, * * * p<0.001)$. 


\subsection{Results}

\section{AQP1 is expressed in human pulmonary vascular cells}

In a next step, the basal expression levels of AQP1 in HPASMC and HPAEC, the two main cell types being involved in the process of vascular remodelling, were investigated. Both cell types express AQP1 on mRNA as well as protein levels. An increased mRNA expression of AQP1 in HPAEC was observed compared to HPASMC (e.g. $\Delta \mathrm{C}_{\mathrm{t}}$ of $8.74 \pm 2.01$ in HPAEC donor \#1 vs. $\Delta \mathrm{C}_{\mathrm{t}}$ of $15.09 \pm 0.56$ in HPASMC donor \#2, $p<0.05$; Fig. 2a). On protein level, there was no significant difference in the expression levels of AQP1 between the two donors of pulmonary vascular cell types (Fig. 2b).
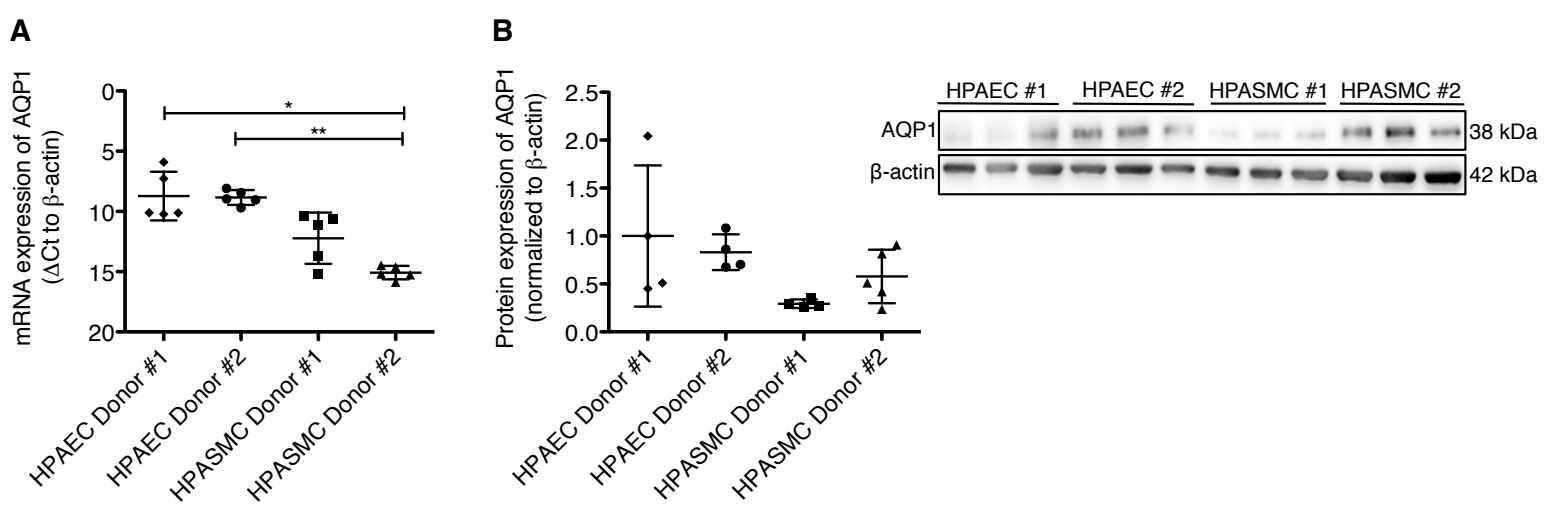

Figure 2. AQP1 is expressed in human pulmonary vascular cells. Human pulmonary artery endothelial (HPAEC) and smooth muscle cells (HPASMC) express AQP1 on mRNA (a) as well as protein (b) level. A representative western blot is shown $(30 \mu \mathrm{g}) . n=4-5$ per group. Statistical analysis by Kruskal-Wallis test with Dunn's post hoc test (a) and one-way ANOVA with Tukey post hoc test (b) $(* p<0.05, * * p 0.01)$.

\section{Exposure to hypoxia drives the expression of AQP1 in human pulmonary vascular cells}

To further investigate the role of AQP1 in hypoxia-induced $\mathrm{PH}$, pulmonary cells were exposed to hypoxia over different time points $\left(1 \% \mathrm{O}_{2}\right.$ for $\left.2-72 \mathrm{~h}\right)$. As indicated in Fig. 3a, HPAEC showed the highest peak in AQP1 mRNA expression after $8 \mathrm{~h}$ of hypoxic exposure (by $1.63 \pm 1.12$ fold change, not significant; donor \#1), whereas long-term hypoxia (24-72 h) decreased mRNA levels with a significant reduction after $72 \mathrm{~h}$ in donor \#2 (reduction to 0.07 $\pm 0.04, p<0.05$ ). mRNA levels of AQP1 in HPASMC (donor \#1) were significantly upregulated after $8 \mathrm{~h}$ (by $2.18 \pm 0.80$ fold change, $p<0.05$ ), 24 h (by $2.87 \pm 0.89$ fold change, $p<0.001$ ), and $48 \mathrm{~h}$ (by $2.10 \pm 0.34$ fold change, $p<0.05$ ) of hypoxic exposure. In donor $\# 2$, however, hypoxia did not change AQP1 mRNA levels (Fig. 3b). Protein expression of AQP1 in HPAEC was only found significant after $72 \mathrm{~h}$ of hypoxia in donor \#2 (by $1.88 \pm 0.49$ fold change, $p<0.01$; Fig. 3c). In contrast, long-term hypoxia increased AQP1 protein levels in HPASMC, with a significant elevation after $48 \mathrm{~h}$ (by $1.80 \pm 0.36$ fold change, $p<0.05$; donor $\# 1$ ) and, e.g. 72 h (by $2.18 \pm 0.15$ fold change, $p<0.001$; donor \#2) of hypoxic exposure (Fig. 
3d). Successful application of the hypoxic condition is indicated by representative Western blots of HIF-1 $\alpha$ stabilization (Fig. 3c, d) as well as marked increase in mRNA levels of the HIF-1 $\alpha$ inducible gene VEGF $\alpha$ (positive control, data not shown).
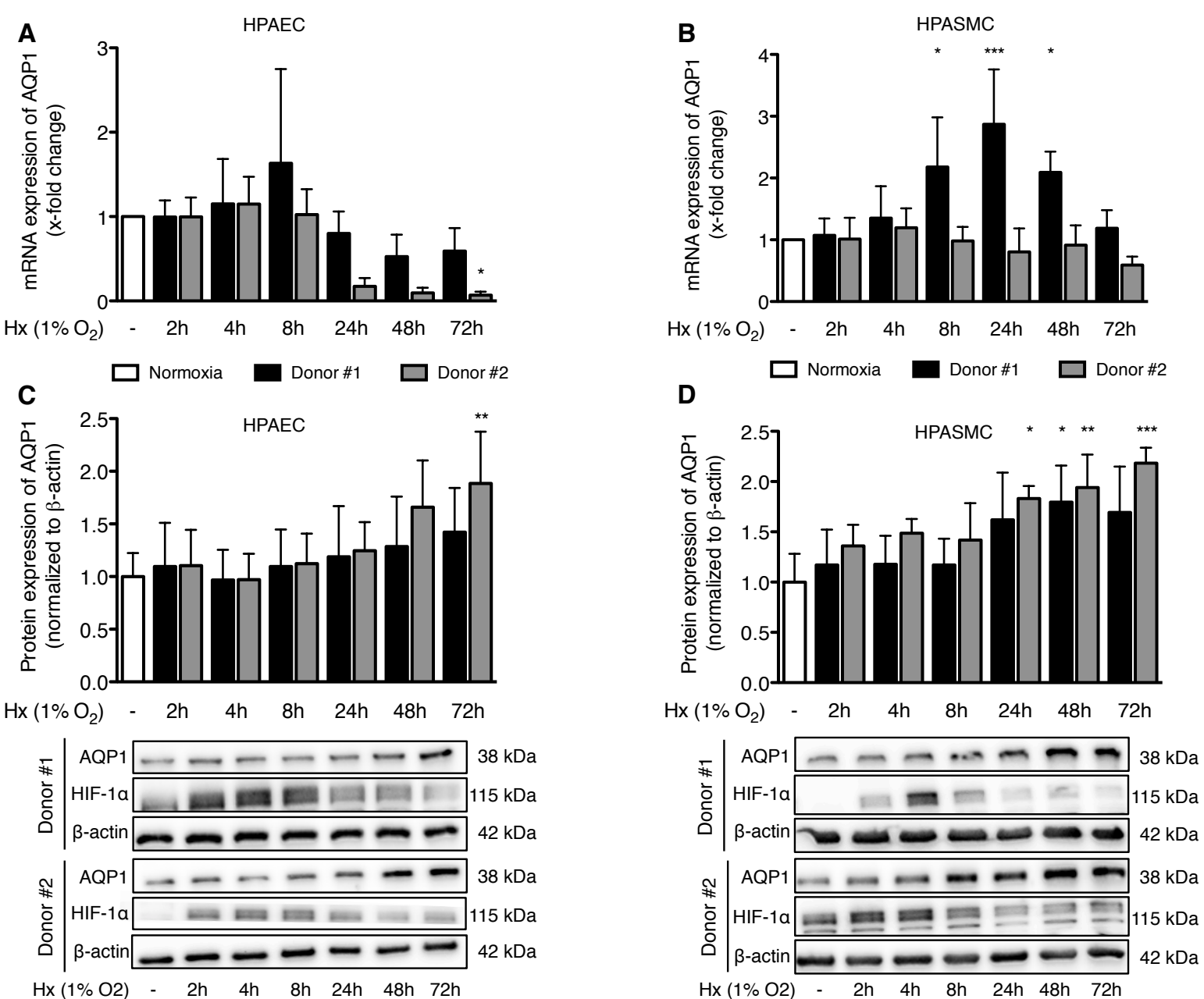

Figure 3. Exposure to hypoxia drives the expression of AQP1 in human pulmonary vascular cells. Two different donors for both vascular cell types were exposed to hypoxia $\left(1 \% \mathrm{O}_{2}\right.$ for $\left.2-72 \mathrm{~h}\right)$. (a, b) Effect of hypoxia on mRNA levels in HPAEC and HPASMC. $(\mathbf{c}, \mathbf{d})$ Effect of hypoxia on protein levels in HPAEC and HPASMC. Representative Western blots are provided $(30 \mu \mathrm{g})$. Immunodetection of HIF-1 $\alpha$ was used to confirm successful application of hypoxia. $n=5-6$ per group. Statistical analysis by Kruskal-Wallis test with Dunn's post hoc test (a, c) and one-way ANOVA with Tukey post hoc test $(\mathbf{b}, \mathbf{d})\left({ }^{*} p<0.05,{ }^{* *} p<0.01,{ }^{* * *} p<0.001\right)$.

\section{Silencing of AQP1 affects the phenotype of human pulmonary artery smooth muscle} cells

Since there was no difference in the amount of AQP1 protein expression in HPASMC and HPAEC (Fig. 2b) and the fact that HPASMC responded best to the hypoxic condition (Fig. 3), we focused on the latter cell type to continue with and to perform the following experiments and functional assays.

To evaluate the physiological role of AQP1 in the process of migration, proliferation, and 


\subsection{Results}

apoptosis in HPASMC, the endogenous expression of AQP1 was silenced by transfection with GapmeRs. As measured by qPCR, transfection of HPASMC with GapmeR targeting AQP1 significantly reduced the expression of AQP1 compared to non-transfected and negative control transfected cells in donor \#1 (by $0.42 \pm 0.19$ fold change, $p<0.01$; Fig. 4a). In addition, these data were confirmed on protein level by Western blots demonstrating a significant decrease of AQP1 protein levels in donor \#1 (by $0.66 \pm 0.13$ fold change, $p<0.01$; Fig. 4b).

In terms of migration, as shown in Fig. 4c, silencing of AQP1 in HPASMC significantly lowered the rate of healing in wound-healing assays (e.g. after $7 \mathrm{~h}$ of migration: GapmeR negative control 39.38\% \pm 5.00 vs. GapmeR AQP1 28.88\% $\pm 7.86, p<0.001$; donor \#1). Representative pictures of migrated HPASMC are provided in Supplementary Figure 1. Likewise, as assessed by BrdU incorporation assay, transfection with GapmeR AQP1 resulted in a significantly reduced proliferation rate of HPASMC (donor \#1) compared to nontransfected and GapmeR negative control transfected cells (in absorbance at $450 \mathrm{~nm}$ : GapmeR negative control $1.76 \pm 0.17$ vs. GapmeR AQP1 $1.45 \pm 0.24, p<0.01$; Fig. 4d). Conversely, HPASMC depleted of AQP1 showed significantly higher caspase 3/7 activity compared to both non-transfected and negative control transfected cells (in relative luminescence units: GapmeR negative control $4138 \pm 1106$ vs. GapmeR AQP1 $5558 \pm 1630, p<0.01$; Fig. 4e) indicating a higher degree of spontaneous apoptosis when AQP1 is silenced. All results were confirmed using a second donor of HPASMC.
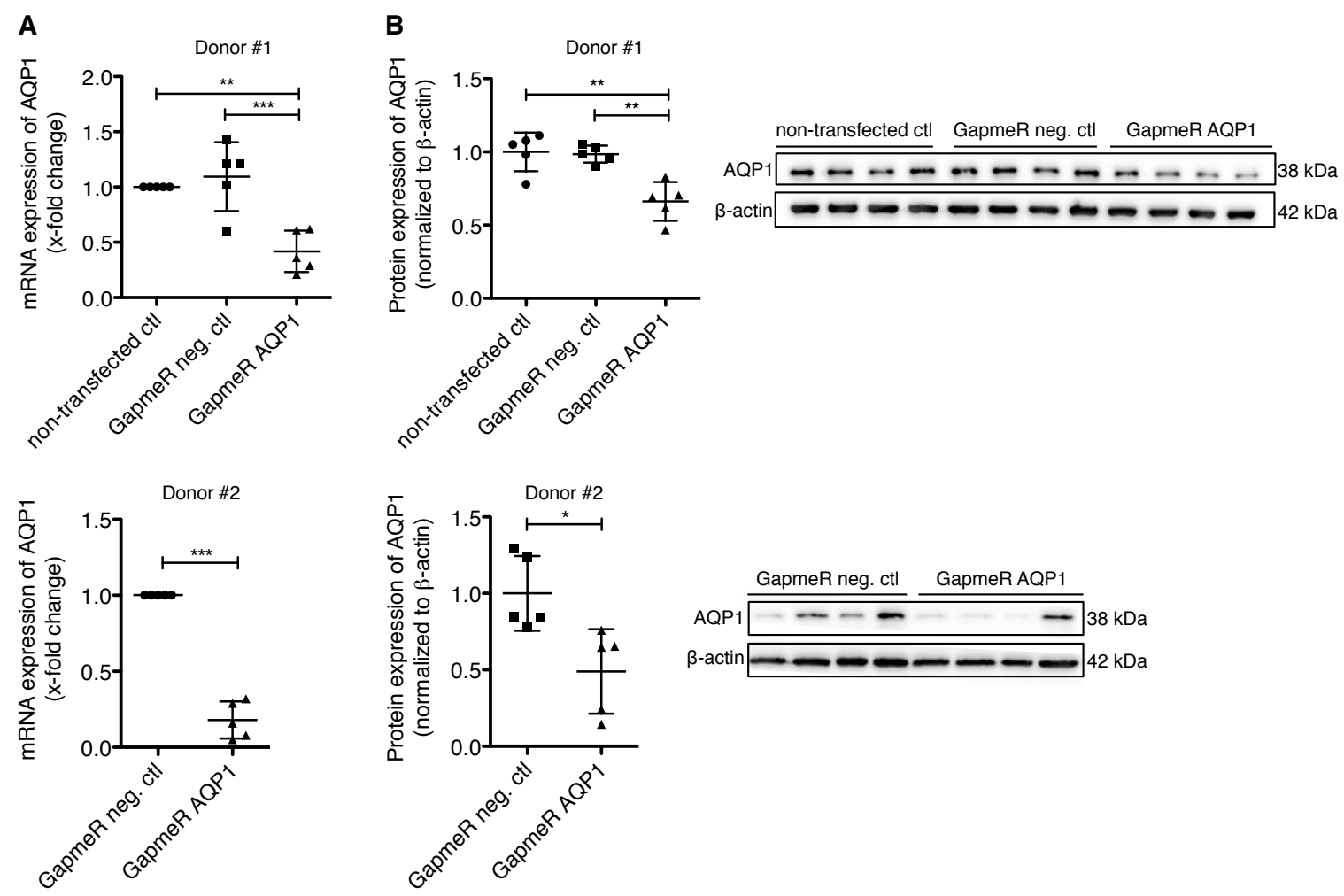

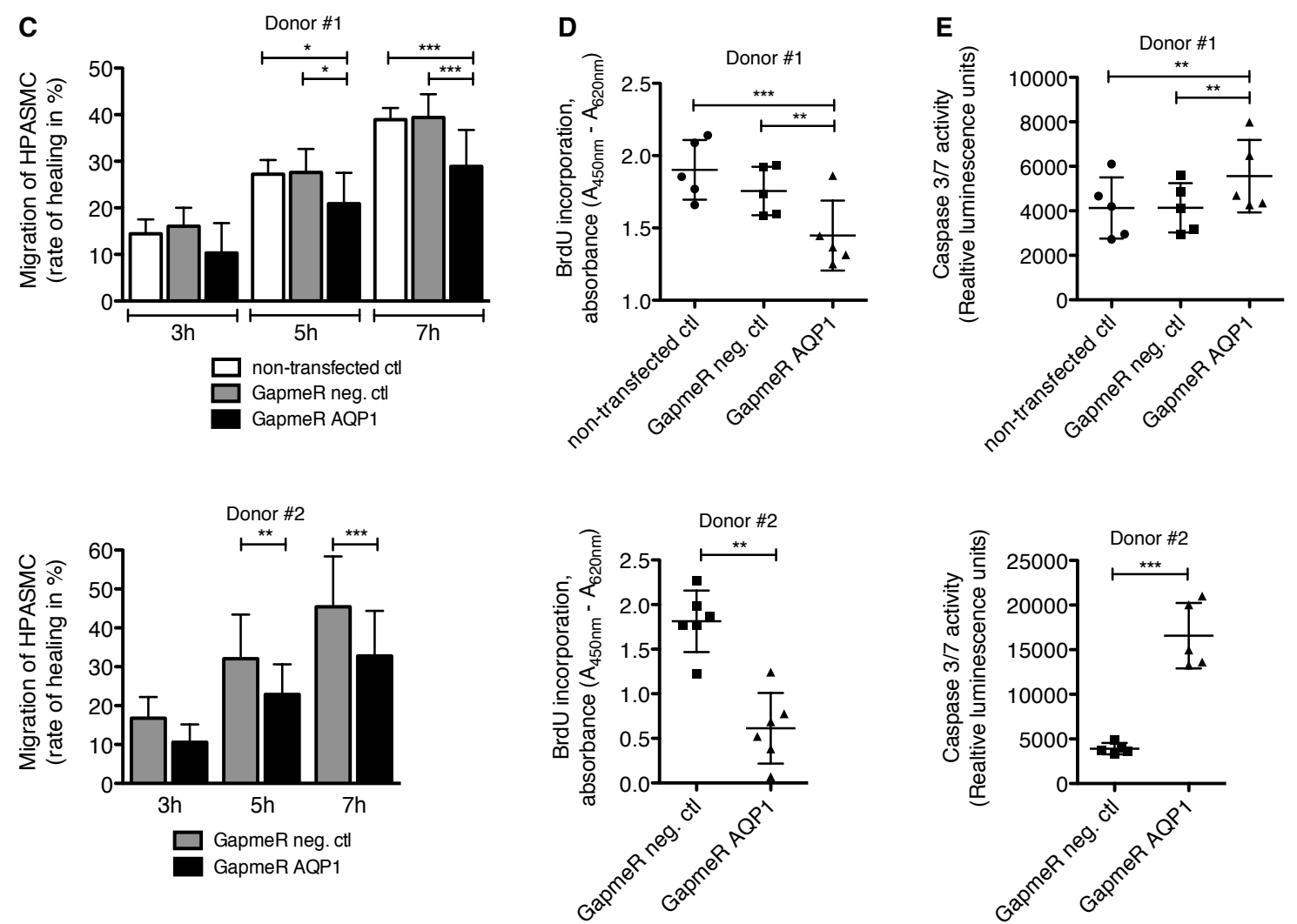

Figure 4. Silencing of AQP1 affects the phenotype of HPASMC. Consequence of GapmeR transfection against AQP1 (25 nmol/L) on both mRNA (a) and protein (b) levels in two donors of HPASMC compared to non-transfected and GapmeR negative control transfected cells. Representative western blots are shown $(30 \mu \mathrm{g})$. Wound-healing (c) and BrdU incorporation (d) assays were performed assessing migration (rate of healing in \%) and proliferation (absorbance at $450 \mathrm{~nm}$ ) of HPASMC after GapmeR AQP1 transfection. (e) Effect of AQP1 depletion in HPASMC on apoptosis as assessed by a luminescent assay that measures caspase-3 and -7 activities simultaneously (relative luminescence units). $n=5-6$ per group. Statistical analysis by repeated-measures ANOVA with Tukey post hoc test (a, b top, c-e top) and paired Student's $t$ test $\left(\mathbf{a}, \mathbf{b}, \mathbf{d}, \mathbf{e}\right.$ bottom) $\left({ }^{*} p<0.05\right.$, $* * p<0.01, * * * p<0.001)$.

\section{Silencing of AQP1 affects the phenotype of hypoxic human pulmonary artery smooth muscle cells}

To investigate the function of AQP1 under hypoxic conditions, HPASMC were transfected with GapmeR AQP1 and exposed to hypoxia, and, $48 \mathrm{~h}$ later, their functional profile was assessed. As indicated in Fig. 5a, inhibiting AQP1 resulted in significantly less hypoxic migration of HPASMC compared to non-transfected as well as negative control transfected cells (e.g. donor $\# 1$ : rate of healing in \% after $7 \mathrm{~h}$ : Hx GapmeR negative control $31.88 \% \pm$ 4.06 vs. Hx GapmeR AQP1 10.45\% $\pm 4.36, p<0.001)$. Representative pictures of migrated HPASMC are provided in Supplementary Figure 2. In addition, hypoxic HPASMC depleted of AQP1 showed significantly lower proliferation compared to control transfected cells 


\subsection{Results}

(donor \#1 in absorbance at $450 \mathrm{~nm}$ : Hx GapmeR negative control $0.57 \pm 0.21$ vs. Hx GapmeR AQP1 $0.17 \pm 0.04, p<0.01$; Fig. 5b). Of note, GapmeR neg. control transfected cells had significantly less proliferation rates compared to hypoxic non-transfected control cells. Moreover, in terms of apoptosis, HPASMC transfected with GapmeR AQP1 and exposed to hypoxia showed significantly higher caspase $3 / 7$ activity in comparison to both control setups (donor \#1 in relative luminescence units: e.g. Hx GapmeR negative control $1415 \pm 181$ vs. Hx GapmeR AQP1 $8538 \pm 767, p<0.001$; Fig. 5c). Using a second donor of HPASMC, all results were confirmed. In summary, our experiments highlight the importance of AQP1 in the regulation of apoptosis, migration, and proliferation of HPASMC in normoxic as well as hypoxic conditions.

A
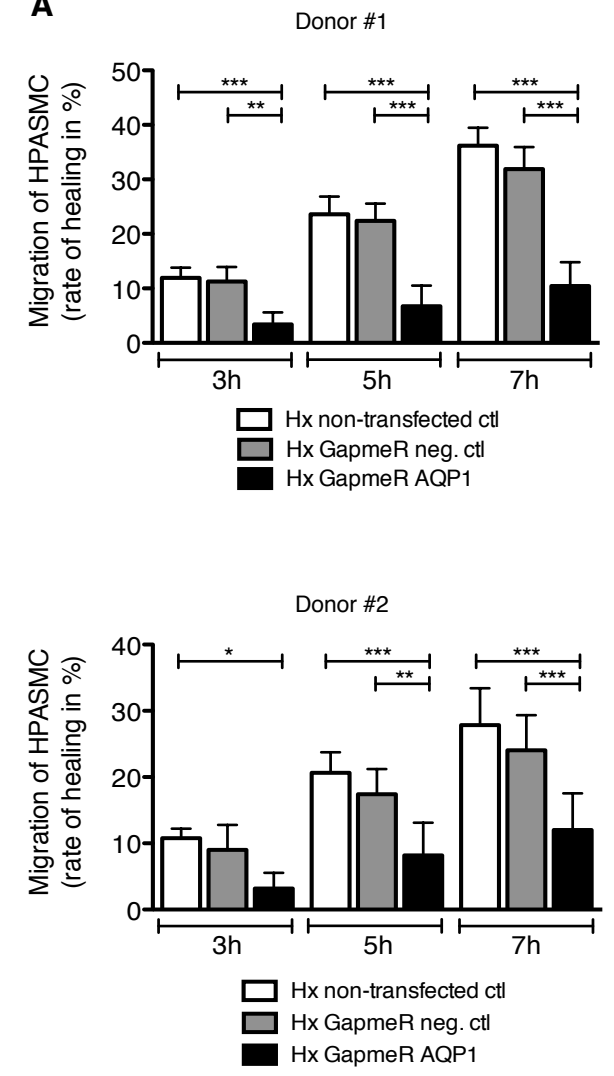

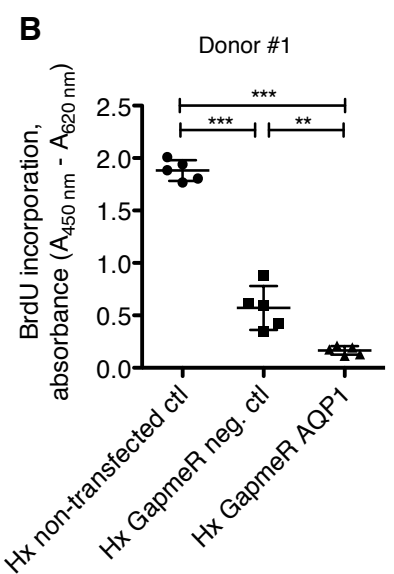

C
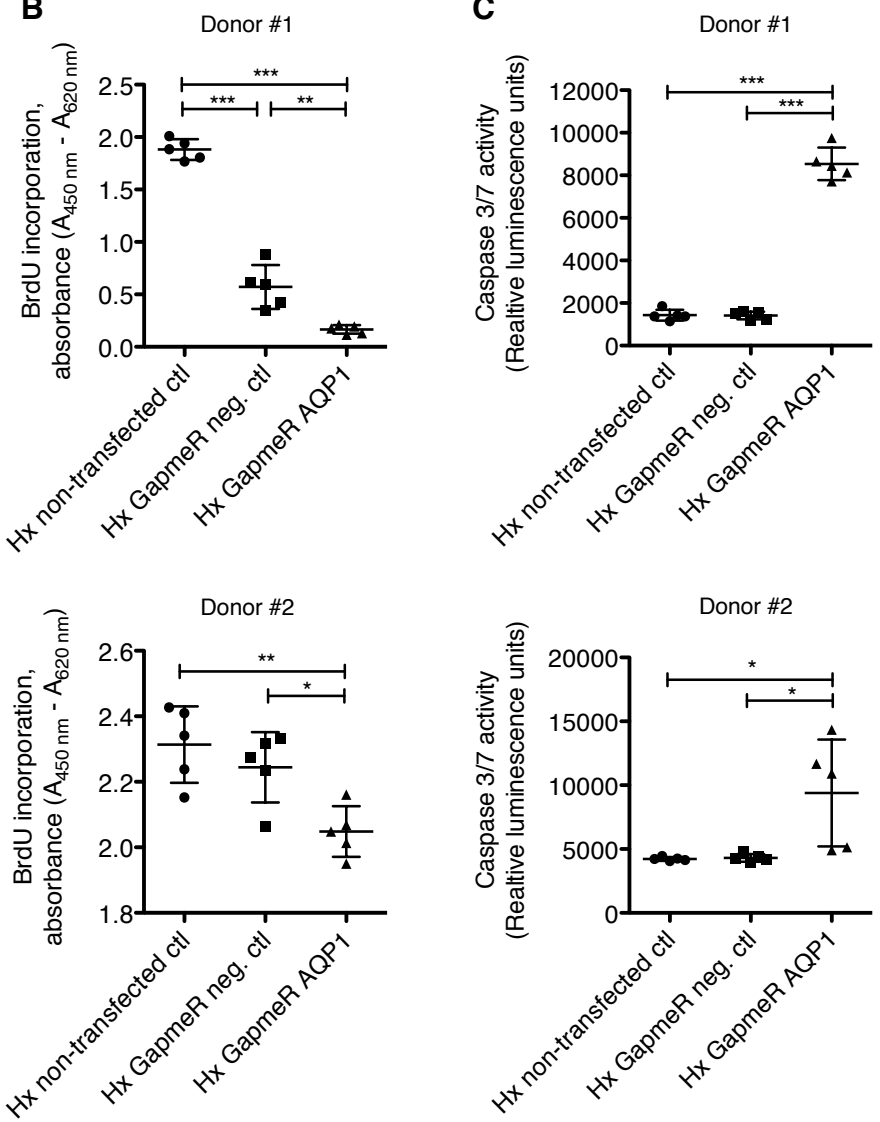

Figure 5. Silencing of AQP1 affects the phenotype of hypoxic HPASMC. Cells were transfected with GapmeR AQP1 $(25 \mathrm{nmol} / \mathrm{L})$, exposed to hypoxia and, $48 \mathrm{~h}$ later, their functional profile was assessed. Migratory (a) (rate of wound healing in \%) and proliferative (b) (absorbance at $450 \mathrm{~nm}$ ) responses of HPASMC after depletion of AQP1 via GapmeR compared to control cells. (c) Apoptosis of HPASMC transfected with GapmeR targeting AQP1 as evaluated by a luminescent assay that measures caspase- 3 and -7 activities simultaneously (relative luminescence units). $n=5-6$ per group. Statistical analysis by repeated-measures ANOVA with Tukey post hoc test $(\mathbf{a}-\mathbf{c})\left({ }^{*} p<0.05,{ }^{* *} p<0.01,{ }^{* * *} p<0.001\right)$. 


\section{AQP1 controls the expression of $p 53$ in human pulmonary artery smooth muscle cells}

To elucidate the molecular mechanism of AQP1 depletion in HPASMC, tumour suppressor and cell cycle inhibitor genes that have previously been implicated in the pathogenesis of $\mathrm{PH}$ were characterized in HPASMC transfected with GapmeR targeting AQP1. In detail, the mRNA levels of p53, BCL2, CDKN1A, and CDKN2A were measured by qPCR demonstrating a significant upregulation of p53 after transfection with GapmeR targeting AQP1 (by $1.43 \pm 0.15$ fold change for donor \#1 and by $3.18 \pm 0.54$ fold change for donor \#2, $p<0.001$; Fig. 6a), whereas no significant changes could be observed when the expression of the other genes was assessed (data not shown). Along that line, protein levels of p53 were significantly increased in both donor \#1 by $2.97 \pm 0.77$ fold change $(p<0.001)$ and donor \#2 by $5.18 \pm 3.18$ fold change $(p<0.05$; Fig. $6 \mathrm{~b}$ ) when AQP1 was depleted in HPASMC compared to negative control transfected cells. Of interest, the expression of p53 was decreased in both HPASMC donors exposed to long-term hypoxia (e.g. $72 \mathrm{~h}$ of hypoxia: 0.71 \pm 0.11 fold change for donor $\# 1$ and $0.55 \pm 0.20$ fold change for donor $\# 2, p<0.01$; Fig. $6 \mathrm{c}$ ). Western blots confirmed these results on protein level demonstrating a significant decrease of p53 after $72 \mathrm{~h}$ of hypoxia in donor \#1 and \#2 (0.67 \pm 0.11 fold change and $0.52 \pm 0.05$ fold change, respectively, $p<0.05$; Fig. 6d). These results highlight the regulation of the expression of $\mathrm{p} 53$ by AQP1 and hypoxia in HPASMC.
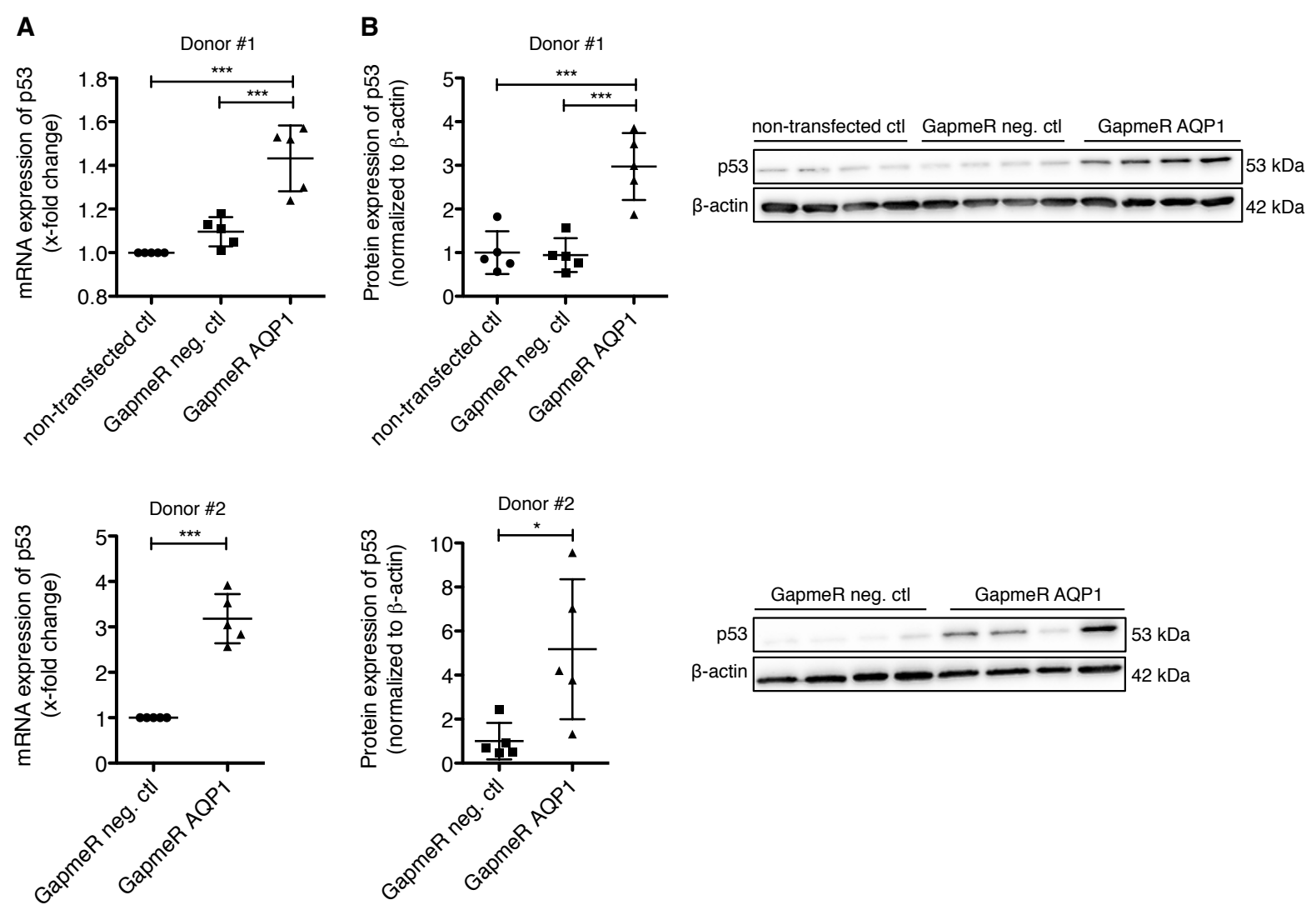

$$
\text { (1) }
$$

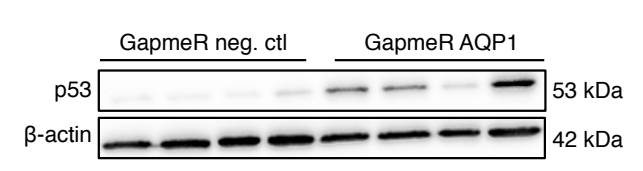



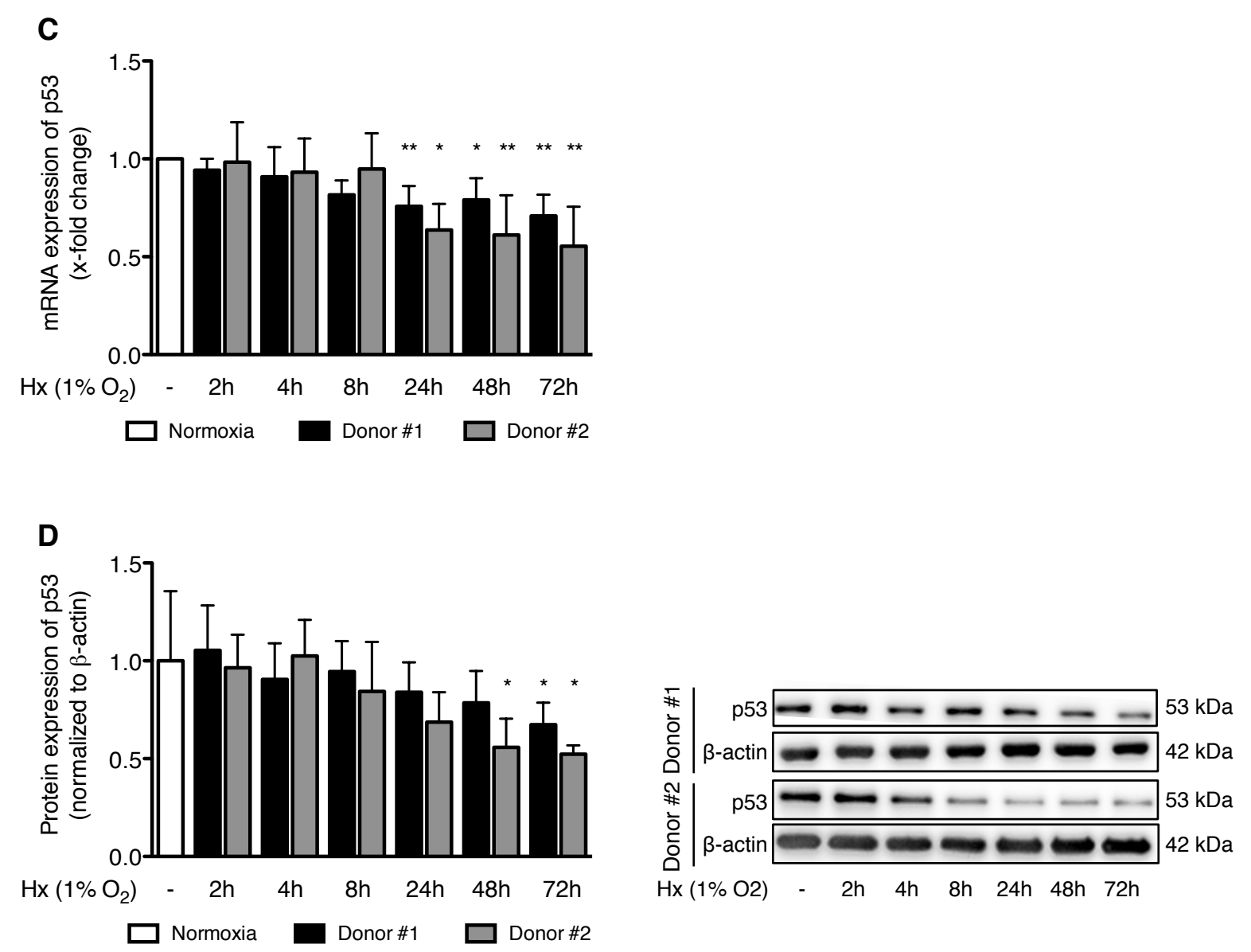

Figure 6. AQP1 controls the expression of p53 in HPASMC. Upon transfection with GapmeR targeting AQP1 (25 nmol/L), mRNA (a) and protein (b) levels of p53 in two donors of HPASMC were evaluated relatively to control cells. Effect of hypoxia $\left(1 \% \mathrm{O}_{2}\right.$ for 2-72 h) in HPASMC on mRNA (c) and protein (d) expression of p53. Representative western blots are provided $(30 \mu \mathrm{g}) . n=5-6$ per group. Statistical analysis by repeated-measures ANOVA with Tukey post hoc test (a, $\mathbf{b}$ top), paired Student's $t$ test (a, b bottom), and oneway ANOVA with Tukey post hoc test $(\mathbf{c}, \mathbf{d})\left({ }^{*} p<0.05,{ }^{* *} p<0.01,{ }^{* *} p<0.001\right)$.

\section{Enforced expression of AQP1 enhances migration and proliferation of human pulmonary artery smooth muscle cells}

To further confirm the role of AQP1 in the context of pulmonary vascular remodelling, AQP1 overexpression studies were performed in HPASMC. As demonstrated by the representative Western blot in Fig. 7a, protein expression of AQP1 was significantly increased after transfection with pcDNA_AQP1 (donor $\# 1$ by $13.76 \pm 3.72$ fold change, $p<0.001$ ). Regarding the migratory potential, HPASMC overexpressing AQP1 migrated faster than control cells as assessed by wound-healing assay (e.g. donor \#1: rate of healing in $\%$ after $7 \mathrm{~h}$ : pcDNA_empty $17.88 \% \pm 5.52$ vs. pcDNA_AQP1 $24.83 \% \pm 5.36, p<0.001$; Fig. $7 b$ ). Representative pictures of migrated HPASMC are provided in Supplementary Figure 3. Moreover, as assessed by BrdU incorporation assay, HPASMC overexpressing AQP1 showed 
enhanced proliferation rates compared to HPASMC transfected with empty control vector (donor \#1 in absorbance at $450 \mathrm{~nm}$ : pcDNA_empty $0.57 \pm 0.17$ vs. pcDNA_AQP1 $0.77 \pm$ $0.18, p<0.01$; Fig. 7c). All results were confirmed using a second donor of HPASMC.
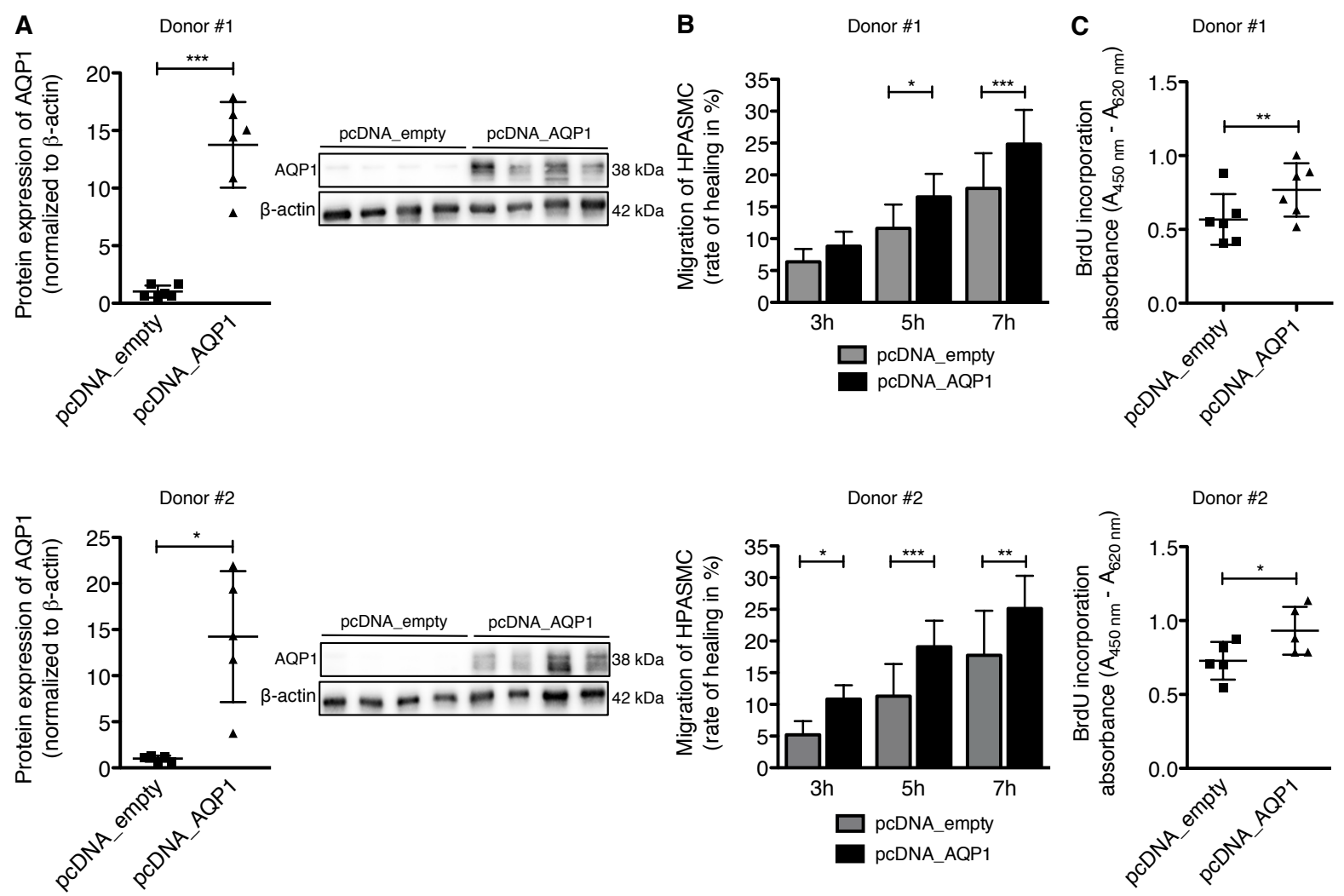

Figure 7. Enforced expression of AQP1 enhances migration and proliferation of HPASMC. Cells were transfected with a vector overexpressing AQP1 (pcDNA_AQP1). (a) AQP1 protein levels after transfection with pcDNA_AQP1 $(0.25 \mu \mathrm{g})$ compared to empty control vector transfected cells (pcDNA_empty). A representative western blot is shown $(30 \mu \mathrm{g})$. Migration (b) and proliferation (c) in AQP1 overexpressing HPASMC compared to control transfected cells as assessed by wound-healing (rate of healing in \%) and BrdU incorporation (absorbance at $450 \mathrm{~nm}$ ) assays. $n=5-6$ per group. Statistical analysis by paired Student's $t$ test (a, c) and repeated-measures ANOVA with Tukey post hoc test $(\mathbf{b})(* p<0.05, * * p<0.01, * * * p<0.001)$.

\section{Silencing of AQP1 reduces right ventricular pressure in the mouse model of hypoxia- induced PH}

The physiological consequences of AQP1 depletion via intervention experiments were further addressed in vivo by employing the hypoxia-induced mouse model of PH. The in vivo experiments were performed as described in the section 'Methods' (Fig. 8a).

As shown in Fig. 8b, hypoxic control mice showed a significant increase in RVP compared to normoxic animals (in $\mathrm{mmHg}, 38.40 \pm 3.71$ vs. $30.33 \pm 2.32, p<0.05$ ) confirming the development of PH. Repeated i.p. injections of negative control GapmeR had no effect on RVP, since RVP stayed significantly elevated in comparison with normoxic control. In 


\subsection{Results}

contrast, treatment with GapmeR targeting AQP1 significantly reduced RVP in these mice compared to hypoxic GapmeR negative control mice (hypoxic GapmeR AQP1 mice $29.77 \pm$ 8.08 vs. hypoxic GapmeR negative control mice $41.00 \pm 3.40, p<0.01$; Fig. 8b). Importantly, after treatment with GapmeR AQP1, RVP of these mice dropped to the same level as in normoxic control animals (Fig. 8b). Of note, systemic arterial pressure and haematocrit were not affected by GapmeR application indicating selective effects of GapmeR within the pulmonary circulation (Fig. 8c, d). Planimetric analysis of the ratio between right ventricular and left ventricular diameter including interventricular septum $[\mathrm{RV} /(\mathrm{LV}+\mathrm{S})]$ showed a significant increase of the right ventricular volume following exposure to hypoxia $(0.295 \pm$ $0.079)$ as compared to normoxic controls $(0.183 \pm 0.039, p<0.01)$. Upon treatment with GapmeR against AQP1, the ratio was decreased (0.204 $\pm 0.029, p<0.05$; Fig. 8e).

In lung tissue collected from these mice, AQP1 mRNA levels were significantly elevated after hypoxic exposure compared to normoxic control mice (by $1.36 \pm 0.14$ fold change, $p<0.01$; Fig. 8f) being in line with Fig. 1b. Moreover, repeated i.p. injections of GapmeR targeting AQP1 significantly downregulated mRNA levels of AQP1 in lung tissue compared to hypoxic GapmeR negative control animals (hypoxic GapmeR negative control mice $1.24 \pm 0.28$ fold change vs. hypoxic GapmeR AQP1 mice $0.97 \pm 0.14$ fold change, $p<0.05$; Fig. 8f). Treatment with GapmeR AQP1 had no effect on mRNA levels of other AQPs expressed in the lung (AQP2-5), confirming specificity of the GapmeR design. Hypoxia, however, was able to significantly upregulate the expression of AQP4 and AQP5 (Supplementary Figure 4).

Affirming the results of the mRNA expression analysis, protein expression of AQP1 was found to be significantly upregulated in both hypoxic and hypoxic GapmeR negative control mice compared to normoxic control animals (hypoxic mice, by $2.77 \pm 1.23$ fold change, hypoxic GapmeR negative control mice, by $2.90 \pm 0.87$ fold change, $p<0.01$ and $p<0.001$, respectively; Fig. 8g). Administration of GapmeR AQP1 tended to reduce the protein expression of AQP1 to levels between normoxic and hypoxic animals (hypoxic GapmeR AQP1 mice $2.02 \pm 0.67$ fold change vs. normoxic mice $1.00 \pm 0.36$ fold change, not significant; Fig. 8g).

A

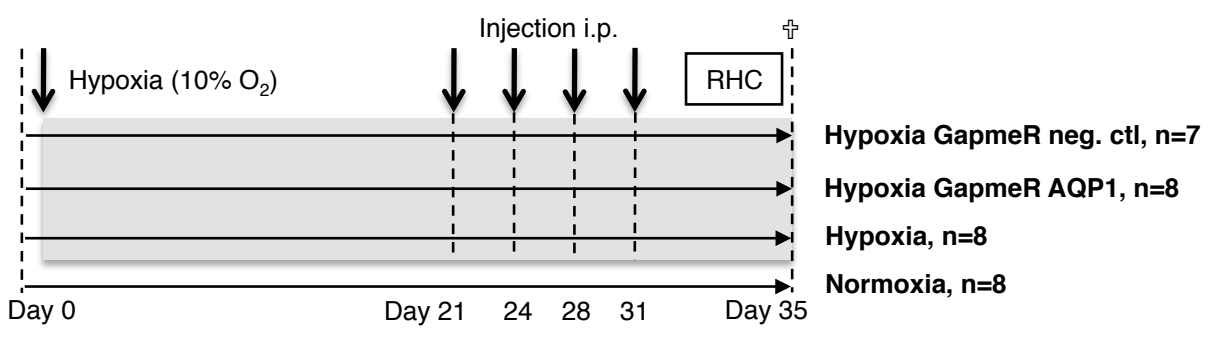




\section{B}

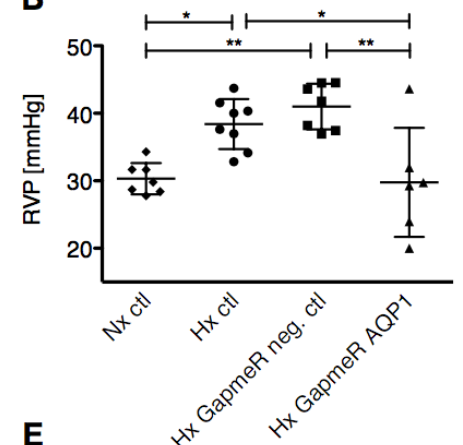

E

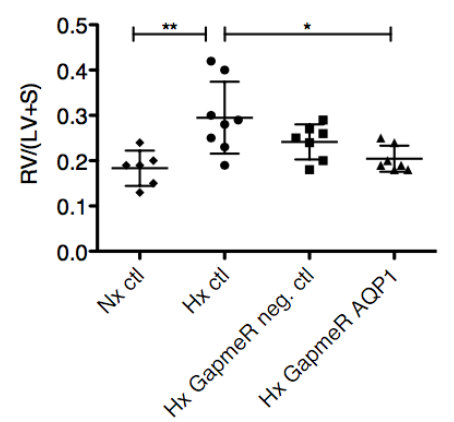

C
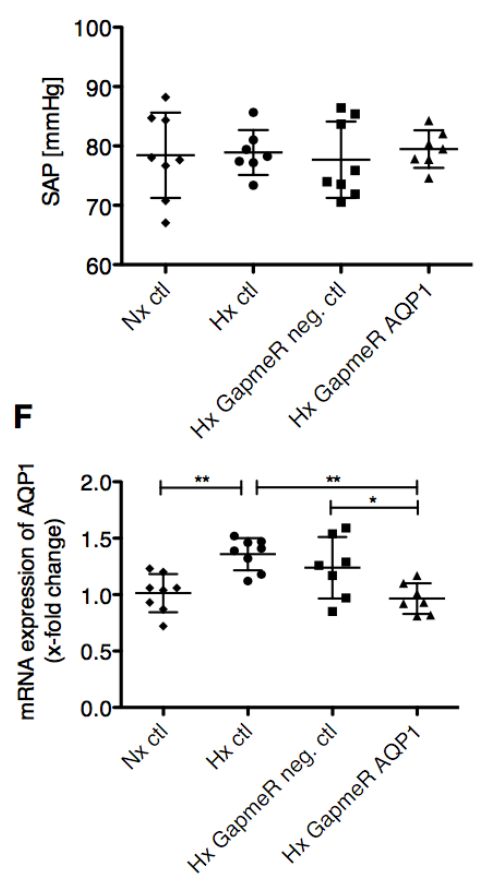

D
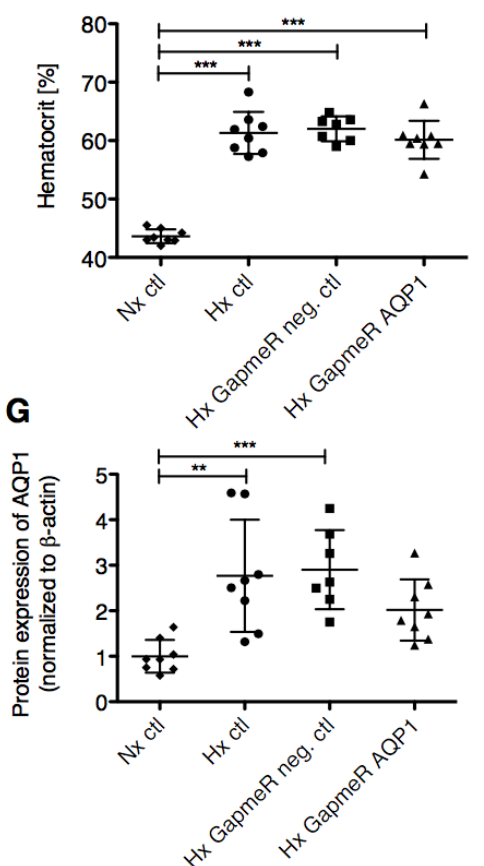

$\mathrm{Nxctl} \quad \mathrm{Hxctl}$ Hx GapmeR ctl Hx GapmeR AQP

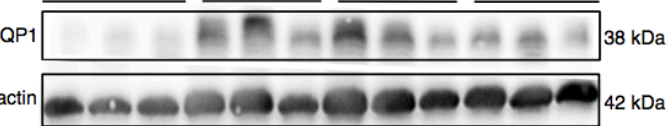

Figure 8. Silencing of AQP1 reduces right ventricular pressure in the mouse model of hypoxia-induced

PH. (a) Study design of the in vivo experiments. Four groups of eight animals each ( $n=7$ for hypoxia GapmeR negative control) were used: three groups were employed in conditions at $10 \% \mathrm{O}_{2}$ for 5 weeks and, after 3 weeks, treated either with GapmeR negative control or GapmeR AQP1 (both $10 \mathrm{mg} / \mathrm{kg}$ ). Injections were performed intraperitoneally (i.p.) every fourth day. One group served as a normoxic control group. Haemodynamic assessment of the mouse model of hypoxia-induced PH shows (b) right ventricular pressure (RVP, in $\mathrm{mmHg}$ ) measured by right heart catheterization (RHC), (c) systemic arterial pressure ( $\mathrm{SAP}$, in $\mathrm{mmHg}$ ), and (d) haematocrit (\%) in the three hypoxic ( $\mathrm{Hx})$ mouse groups compared to normoxic $(\mathrm{Nx})$ animals. (e) Planimetric analysis of the ratio between the right and left ventricular volume including interventricular septum wall $[\mathrm{RV} /(\mathrm{LV}+\mathrm{S})](n=6-8)$. Effect of hypoxia and GapmeR treatment on AQP1 mRNA (f) and protein (g) expression in lung homogenates measured by qPCR and western blot $(n=7-8)$. A representative western blot is provided $(30 \mu \mathrm{g})$. Statistical analysis by one-way ANOVA with Tukey post hoc test $(\mathbf{b}-\mathbf{g})\left({ }^{*} p<0.05,{ }^{*} p<\right.$ $\left.0.01,{ }^{* * *} p<0.001\right)$.

\subsection{DISCUSSION}

Aquaporin 1 is known to be induced by hypoxia which itself might be both a causative factor for and a consequence of elevated pulmonary pressure. Of interest, however, the physiological consequence of the manipulation of AQP1 expression has not been described in the context of hypoxia-induced PH so far. In this study, we confirmed the previous findings showing that hypoxic conditions increase the expression of AQP1 both in vitro and in vivo 


\subsection{Discussion}

[14]. In addition, we demonstrated that manipulation of AQP1 affects the expression of the tumour suppressor gene p53 and influences the functional profile of pulmonary vascular cells on a migratory, proliferative, and apoptotic level. By employing the hypoxia-induced $\mathrm{PH}$ mouse model, we found that silencing of AQP1 by a novel chimeric antisense oligonucleotide technology (GapmeRs) reversed established PH. Taken together, these findings represent the first direct link between AQP1 and PH and provide a novel interesting target to address pulmonary hypertension.

It was previously reported that AQP1 is induced by hypoxia in pulmonary artery smooth muscle cells. In detail, rat pulmonary artery smooth muscle cells exposed to hypoxia selectively increased AQP1 protein levels and, in turn, migration. Silencing of AQP1 via siRNA prevented the hypoxia-induced migration in these cells [13, 14]. Our initial experiments confirmed these findings by showing that the levels of AQP1 are increased by hypoxia in pulmonary artery smooth muscle cells. Of note, the observed induction of AQP1 could not be directly linked to the stabilization of HIF-1 $\alpha$ suggesting the involvement of other mechanisms [1], for example the additional influx of calcium or interaction with microRNAs as suggested previously $[14,22]$. The multi-factorial and complex induction of AQP1 by hypoxia is further emphasized by variable mRNA levels between the two donors. While the exact mechanisms behind these findings are elusive, high protein levels and functional data were consistently retrieved in long-term exposed HPASMC. Moreover, in lung tissue samples of animals exposed to hypoxia for 5 weeks, we found a significant increase in the expression of AQP1 compared to normoxic controls. Levels of AQP1 could be further correlated with pulmonary haemodynamics indicating that mice with higher AQP1 expression levels have increased right ventricular pressures and vice versa. Functional experiments and a subsequent treatment trial emphasized that this correlation might reflect causality and not only association.

Pulmonary artery smooth muscle cells showed an increased migratory response and dysregulation of the cell growth with development of a pro-proliferative and anti-apoptotic phenotype. Remodelling of small pulmonary arteries is the major factor in the pathobiology of $\mathrm{PH}$ and is, to date, not adequately addressed by modern PH-target therapies. Along that line, a recent publication demonstrated that genetic deletion of endothelial guanylyl cyclase-A receptor in mice caused pulmonary vascular remodelling, probably due to increased vascular cell proliferation, and $\mathrm{PH}$ already under normoxic conditions, since the atrial natriuretic peptide (ANP) cannot exert its protective effects. This experimental study underpins the importance for novel strategies to target or even reverse pulmonary vascular remodelling and 
PH [38]. Vascular remodelling in the pulmonary circulation is characterized by migration of endothelial cells reflecting angiogenesis [36], formation of a "neo-intima" [20], and, most important, uncontrolled proliferation of smooth muscle cells [5]. These changes that result in progressive hyperplasia of the medial vessel layer and luminal obliteration have been described as neoplastic-like processes [29]. Since AQPs have been associated with malignant transformation and the development of cancer, our results might provide a novel mechanism explaining similar transformation in vessels of patients with $\mathrm{PH}$. One of the best characterized tumour suppressor genes is p53 [32] and, in the context of PH, Jacquin et al. showed that p53 is found downregulated in the monocrotaline model of $\mathrm{PH}$. Moreover, inactivation of p53 alone was sufficient to induce the development of experimental PH $[11,16]$. Another study demonstrated that exogenous NO has an inhibitory effect on smooth muscle cell proliferation via induction of p53 and p21 [17]. In our experiments, silencing of AQP1 via GapmeRs resulted in higher mRNA and protein expression of p53. The interaction between p53 and AQP1 was further highlighted in hypoxic HPASMC showing decreased p53 levels with a concomitant increase of AQP1 expression (Fig. 9).

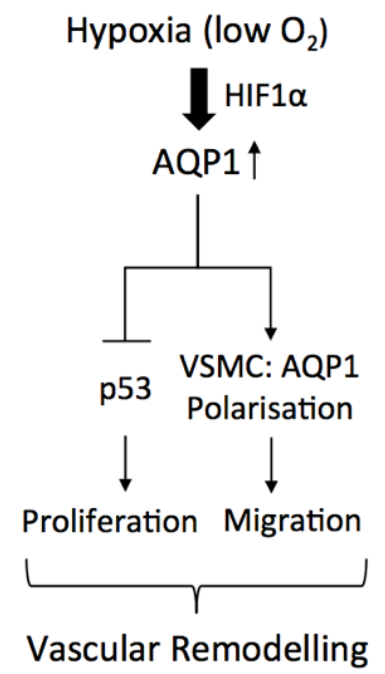

Figure 9. Proposed AQP1-mediated mechanism of vascular remodelling in the context of hypoxiainduced PH. Hypoxia-induced upregulation of AQP1 leads to a reduced expression of the tumour suppressor p53, promoting vascular smooth muscle cell proliferation (left side). As described by Saadoun et al. [23], AQP1 expression polarises to the leading edge of lamellipodia extension, facilitating water influx and cell migration (right side).

In addition, enhanced p53 expression levels were found after silencing of AQP3 with shRNA in a non-small cell lung cancer (NSCLC) model, which was accompanied with suppressed tumour proliferation [39]. AQP3 knockdown reduced cellular glycerol content (AQP3 is an aquaglyceroporin) and mitochondrial ATP formation, which, together with a reduction in PCNA levels, might contribute to the inhibitive effect on tumour proliferation. Of note, the 


\subsection{Discussion}

importance of AQP1 for the vascular smooth muscle phenotype was highlighted in a study by Al Ghouleh et al., demonstrating that reactive oxygen species are channelled via AQP1 resulting in hypertrophy, however, without affecting proliferation [2]. Furthermore, a study investigated the role of the C-terminal tail of AQP1 on migration and proliferation, because the exact mechanism by which AQP1 facilitates these two processes remains unclear [13]. In this setting, the C-terminal was required, since its deletion in AQP1 overexpressing rat smooth muscle cells abolished the effect on both migration and proliferation. They concluded that the possible AQP1-mediated mechanisms include association of factors or proteins with the C-terminal. The exact mechanism how AQP1 executes its function in this context, however, remains elusive and it will be difficult, in general, to unravel the underlying molecular mechanisms that act at the interface of hypoxia, AQP1, and PH.

Another link between AQP1 and proliferation was provided by data on adult carotid body cells, which were observed to proliferate less under hypoxic conditions when analysed in AQP1 knockout mice. Microarray data further revealed alterations in several proliferationregulating genes suggesting that AQP1 modifies the expression of key cell cycle proteins [6]. In a next step, we tried to translate these in vitro findings by antagonizing AQP1 in an experimental model for PH. Animal models used to investigate $\mathrm{PH}$ have major limitations and only partially mimic human disease [8]. However, the hypoxia-induced mouse model is one of the best-established models for PH and, in the context of AQP1 that is strongly driven by hypoxic conditions, represents a suitable in vivo model. Silencing of AQP1 was achieved by administration of GapmeRs directed against AQP1. GapmeRs are single-stranded antisense oligonucleotides that catalyse the RNase $\mathrm{H}$ mediated degradation of complementary RNA targets and are active both in vitro and in vivo. To ensure enhanced stability and high target affinity, GapmeRs are composed of LNA-modified oligonucleotides flanking a central gap of DNA [33]. The usage of GapmeRs to target transcripts of genes of interest in vivo has been shown previously [31].

In this study, repeated intraperitoneal application of GapmeRs resulted in antagonizing of AQP1 and reversed the hypoxia-induced elevation of the pulmonary pressure. This is, to the best of our knowledge, the first report on the successful targeting of AQP1 in vivo through GapmeRs. In turn, as a consequence of reduced AQP1 expression in lung tissue, right ventricular pressure in animals exposed to hypoxia was reduced to levels of normoxic control animals. Performing additional experiments measuring mRNA levels of AQP2-5 in whole tissue from lungs in our GapmeR mouse setting of hypoxia-induced PH confirmed specificity of GapmeR for AQP1, where hypoxia was able to significantly upregulate the expression of 
AQP4 and AQP5 (Supplementary Figure 4). Furthermore, these results indicate that there was no compensational feedback regulation of other AQP subsets due to GapmeR treatment. A limitation of this study is the near absence of right ventricular hypertrophy in the Hx GapmeR neg. ctl group. This might be explained by a combination of methodical limitations of applied morphometric analysis and the relatively high biological variation, which was observed in our hypoxia-induced PH mouse model. Although this mouse model is frequently applied, it is supposed to be a mild one in terms of RVP increase, RVH, and pulmonary vascular remodelling [15]. However, RVP was significantly elevated in this group after hypoxic exposure. Newly established animal models for hypoxia-induced PH, e.g. the Sugen/hypoxia [19], were shown to induce a more pronounced pathological cardiorespiratory phenotype. Nevertheless, our data indicate that the pharmacological use of GapmeRs to target AQP1 reverses hypoxia-induced elevated pulmonary pressure and might treat vascular remodelling. The use of these novel antisense oligonucleotides could be limited by non-specific binding to proteins and off-target effects such as hepatotoxicity [12]. In our experiments, however, no such effects were observed indicating that GapmeR therapy is well tolerated and feasible. In conclusion, this is the first report of AQPs in the context of PH. The identification of AQP1 expression and its functional characterization upon exposure to hypoxia unravels novel and important insights in the pathogenesis of pulmonary vascular remodelling. The therapeutic application of innovative antisense oligonucleotides resulted in successful antagonization of AQP1 and reversed experimental PH. However, it remains elusive at the moment whether these results might offer a future opportunity to target AQP1 in the lungs to prevent vascular remodelling in a selected cohort of patients with $\mathrm{PH}$ in the context of chronic lung disease.

\section{Acknowledgments}

The authors thank Rudolf Speich for his continuous support of our research, his commitment, and enthusiasm to pulmonary hypertension and many invaluable inputs. We are deeply saddened by his unexpected death. Furthermore, we would like to thank Giovanni Pellegrini from the Institute of Veterinary Physiology of the University of Zurich for his assistance with the animal samples. This work was supported by the Swiss National Science Foundation (SNF Grant 31003A 144212); the Swiss Lung Association (LLS-Nr 2014-09); the Hartmann Müller Foundation; and the Novartis Foundation for medical-biological research (16B086).

\section{Compliance with ethical standards}




\section{Ethical standards}

All animal experiments were approved by the Cantonal Veterinary Office Zurich (Approval Numbers 151/2012 and 212/2014) and performed in accordance with the guidelines from Directive 2010/63/EU of the European Parliament as well as with the ethical standards laid down in the 1964 Declaration of Helsinki.

\section{Conflict of interest}

The authors declare that they have no conflicts of interest.

\subsection{REFERENCES}

1. Abreu-Rodriguez I, Sanchez Silva R, Martins AP, Soveral G, Toledo-Aral JJ, LopezBarneo J, Echevarria M (2011) Functional and transcriptional induction of aquaporin1 gene by hypoxia; analysis of promoter and role of Hif-1alpha. PLoS One 6:e28385 doi:10.1371/journal.pone.0028385

2. Al Ghouleh I, Frazziano G, Rodriguez AI, Csanyi G, Maniar S, St Croix CM, Kelley EE, Egana LA, Song GJ, Bisello A, Lee YJ, Pagano PJ (2013) Aquaporin 1, Nox1, and Ask1 mediate oxidant-induced smooth muscle cell hypertrophy. Cardiovasc Res 97:134-142 doi:10.1093/cvr/cvs295

3. Brock M, Haider TJ, Vogel J, Gassmann M, Speich R, Trenkmann M, Ulrich S, Kohler M, Huber LC (2015) The hypoxia-induced microRNA-130a controls pulmonary smooth muscle cell proliferation by directly targeting CDKN1A. Int J Biochem Cell Biol 61:129-137 doi:10.1016/j.biocel.2015.02.002

4. Brock M, Samillan VJ, Trenkmann M, Schwarzwald C, Ulrich S, Gay RE, Gassmann M, Ostergaard L, Gay S, Speich R, Huber LC (2014) AntagomiR directed against miR-20a restores functional BMPR2 signalling and prevents vascular remodelling in hypoxia-induced pulmonary hypertension. Eur Heart J 35:3203-3211 doi:10.1093/eurheartj/ehs060

5. Dorfmuller P, Humbert M (2012) Progress in pulmonary arterial hypertension pathology: relighting a torch inside the tunnel. Am J Respir Crit Care Med 186:210212 doi:10.1164/rccm.201206-1049ED 
6. Galan-Cobo A, Ramirez-Lorca R, Toledo-Aral JJ, Echevarria M (2016) Aquaporin-1 plays important role in proliferation by affecting cell cycle progression. J Cell Physiol 231:243-256 doi:10.1002/jcp.25078

7. Godinas L, Guignabert C, Seferian A, Perros F, Bergot E, Sibille Y, Humbert M, Montani D (2013) Tyrosine kinase inhibitors in pulmonary arterial hypertension: a double-edge sword? Semin Respir Crit Care Med 34:714-724 doi:10.1055/s-00331356494

8. Gomez-Arroyo J, Saleem SJ, Mizuno S, Syed AA, Bogaard HJ, Abbate A, Taraseviciene-Stewart L, Sung Y, Kraskauskas D, Farkas D, Conrad DH, Nicolls MR, Voelkel NF (2012) A brief overview of mouse models of pulmonary arterial hypertension: problems and prospects. Am J Physiol Lung Cell Mol Physiol 302:L977-991 doi:10.1152/ajplung.00362.2011

9. Huber LC, Bye H, Brock M (2015) The pathogenesis of pulmonary hypertension - an update. Swiss Med Wkly 145:w14202 doi:10.4414/smw.2015.14202

10. Huber LC, Ulrich S, Leuenberger C, Gassmann M, Vogel J, von Blotzheim LG, Speich R, Kohler M, Brock M (2015) microRNA-125a in pulmonary hypertension: Regulator of a proliferative phenotype of endothelial cells. Exp Biol Med (Maywood) 240:1580-1589 doi:10.1177/1535370215579018

11. Jacquin S, Rincheval V, Mignotte B, Richard S, Humbert M, Mercier O, LondonoVallejo A, Fadel E, Eddahibi S (2015) Inactivation of p53 Is Sufficient to Induce Development of Pulmonary Hypertension in Rats. PLoS One 10:e131940 doi:10.1371/journal.pone.0131940

12. Kakiuchi-Kiyota S, Koza-Taylor PH, Mantena SR, Nelms LF, Enayetallah AE, Hollingshead BD, Burdick AD, Reed LA, Warneke JA, Whiteley LO, Ryan AM, Mathialagan N (2014) Comparison of hepatic transcription profiles of locked ribonucleic acid antisense oligonucleotides: evidence of distinct pathways contributing to non-target mediated toxicity in mice. Toxicol Sci 138:234-248 doi:10.1093/toxsci/kft278

13. Lai N, Lade J, Leggett K, Yun X, Baksh S, Chau E, Crow MT, Sidhaye V, Wang J, Shimoda LA (2014) The aquaporin 1 C-terminal tail is required for migration and growth of pulmonary arterial myocytes. Am J Respir Cell Mol Biol 50:1010-1020 doi:10.1165/rcmb.2013-0374OC

14. Leggett K, Maylor J, Undem C, Lai N, Lu W, Schweitzer K, King LS, Myers AC, Sylvester JT, Sidhaye V, Shimoda LA (2012) Hypoxia-induced migration in 
pulmonary arterial smooth muscle cells requires calcium-dependent upregulation of aquaporin 1. Am J Physiol Lung Cell Mol Physiol 303:L343-353 doi:10.1152/ajplung.00130.2012

15. Maarman G, Lecour S, Butrous G, Thienemann F, Sliwa K (2013) A comprehensive review: the evolution of animal models in pulmonary hypertension research; are we there yet? Pulm Circ 3:739-756 doi:10.1086/674770

16. Mizuno S, Bogaard HJ, Kraskauskas D, Alhussaini A, Gomez-Arroyo J, Voelkel NF, Ishizaki T (2011) p53 Gene deficiency promotes hypoxia-induced pulmonary hypertension and vascular remodeling in mice. Am J Physiol Lung Cell Mol Physiol 300:L753-761 doi:10.1152/ajplung.00286.2010

17. Mizuno S, Kadowaki M, Demura Y, Ameshima S, Miyamori I, Ishizaki T (2004) p42/44 Mitogen-activated protein kinase regulated by p53 and nitric oxide in human pulmonary arterial smooth muscle cells. Am J Respir Cell Mol Biol 31:184-192 doi:10.1165/rcmb.2003-0397OC

18. Moon C, Preston GM, Griffin CA, Jabs EW, Agre P (1993) The human aquaporinCHIP gene. Structure, organization, and chromosomal localization. J Biol Chem 268:15772-15778

19. Nicolls MR, Mizuno S, Taraseviciene-Stewart L, Farkas L, Drake JI, Al Husseini A, Gomez-Arroyo JG, Voelkel NF, Bogaard HJ (2012) New models of pulmonary hypertension based on VEGF receptor blockade-induced endothelial cell apoptosis. Pulm Circ 2:434-442 doi:10.4103/2045-8932.105031

20. Perros F, Dorfmuller P, Humbert M (2005) Current insights on the pathogenesis of pulmonary arterial hypertension. Semin Respir Crit Care Med 26:355-364 doi:10.1055/s-2005-916149

21. Reinhart-King CA (2008) Endothelial cell adhesion and migration. Methods Enzymol 443:45-64 doi:10.1016/S0076-6879(08)02003-X

22. Rutkovskiy A, Bliksoen M, Hillestad V, Amin M, Czibik G, Valen G, Vaage J, Amiry-Moghaddam M, Stenslokken KO (2013) Aquaporin-1 in cardiac endothelial cells is downregulated in ischemia, hypoxia and cardioplegia. J Mol Cell Cardiol 56:22-33 doi:10.1016/j.yjmcc.2012.12.002

23. Saadoun S, Papadopoulos MC, Hara-Chikuma M, Verkman AS (2005) Impairment of angiogenesis and cell migration by targeted aquaporin-1 gene disruption. Nature 434:786-792 doi:10.1038/nature03460 
24. Schermuly RT, Ghofrani HA, Wilkins MR, Grimminger F (2011) Mechanisms of disease: pulmonary arterial hypertension. Nat Rev Cardiol 8:443-455 doi:10.1038/nrcardio.2011.87

25. Schmittgen TD, Livak KJ (2008) Analyzing real-time PCR data by the comparative C(T) method. Nat Protoc 3:1101-1108

26. Semenza GL (2011) Oxygen sensing, homeostasis, and disease. N Engl J Med 365:537-547 doi:10.1056/NEJMra1011165

27. She J, Bi J, Tong L, Song Y, Bai C (2013) New insights of aquaporin 5 in the pathogenesis of high altitude pulmonary edema. Diagn Pathol 8:193 doi:10.1186/1746-1596-8-193

28. Simonneau G, Gatzoulis MA, Adatia I, Celermajer D, Denton C, Ghofrani A, Gomez Sanchez MA, Krishna Kumar R, Landzberg M, Machado RF, Olschewski H, Robbins IM, Souza R (2013) Updated clinical classification of pulmonary hypertension. J Am Coll Cardiol 62:D34-41 doi:10.1016/j.jacc.2013.10.029

29. Soubrier F, Chung WK, Machado R, Grunig E, Aldred M, Geraci M, Loyd JE, Elliott CG, Trembath RC, Newman JH, Humbert M (2013) Genetics and genomics of pulmonary arterial hypertension. J Am Coll Cardiol 62:D13-21 doi:10.1016/j.jacc.2013.10.035

30. Souza R, Simonneau G (2014) Reply: pulmonary hypertension of sickle cell disease beyond classification constraints. J Am Coll Cardiol 63:2882-2883 doi:10.1016/j.jacc.2014.03.044

31. Straarup EM, Fisker N, Hedtjarn M, Lindholm MW, Rosenbohm C, Aarup V, Hansen HF, Orum H, Hansen JB, Koch T (2010) Short locked nucleic acid antisense oligonucleotides potently reduce apolipoprotein B mRNA and serum cholesterol in mice and non-human primates. Nucleic Acids Res 38:7100-7111 doi:10.1093/nar/gkq457

32. Suzuki K, Matsubara H (2011) Recent advances in p53 research and cancer treatment. J Biomed Biotechnol 2011:978312 doi:10.1155/2011/978312

33. Veedu RN, Wengel J (2010) Locked nucleic acids: promising nucleic acid analogs for therapeutic applications. Chem Biodivers 7:536-542 doi:10.1002/cbdv.200900343

34. Verkman AS (2012) Aquaporins in clinical medicine. Annu Rev Med 63:303-316 doi:10.1146/annurev-med-043010-193843

35. Verkman AS, Anderson MO, Papadopoulos MC (2014) Aquaporins: important but elusive drug targets. Nat Rev Drug Discov 13:259-277 doi:10.1038/nrd4226 


\subsection{References}

36. Voelkel NF, Gomez-Arroyo J (2014) The role of vascular endothelial growth factor in pulmonary arterial hypertension. The angiogenesis paradox. Am J Respir Cell Mol Biol 51:474-484 doi:10.1165/rcmb.2014-0045TR

37. Ward JP, McMurtry IF (2009) Mechanisms of hypoxic pulmonary vasoconstriction and their roles in pulmonary hypertension: new findings for an old problem. Curr Opin Pharmacol 9:287-296 doi:10.1016/j.coph.2009.02.006

38. Werner F, Kojonazarov B, Gassner B, Abesser M, Schuh K, Volker K, Baba HA, Dahal BK, Schermuly RT, Kuhn M (2016) Endothelial actions of atrial natriuretic peptide prevent pulmonary hypertension in mice. Basic Res Cardiol 111:22 doi:10.1007/s00395-016-0541-x

39. Xia H, Ma YF, Yu CH, Li YJ, Tang J, Li JB, Zhao YN, Liu Y (2014) Aquaporin 3 knockdown suppresses tumour growth and angiogenesis in experimental non-small cell lung cancer. Exp Physiol 99:974-984 doi:10.1113/expphysiol.2014.078527

\subsection{SUPPLEMENTARY MATERIAL}

\section{Supplementary Tables}

Supplementary Table 1. Antisense LNA GapmeR sequences used for silencing of AQP1. + = prefix for LNA. Modification: phosphorothioate backbone.

\begin{tabular}{lll}
\hline GapmeR & Sequence & LNA content \\
\hline GapmeR negative ctl & $5^{\prime}-+\mathrm{G}+\mathrm{A}+\mathrm{C}$ TAA TGC ATT $+\mathrm{A}+\mathrm{T}+\mathrm{C}-3{ }^{\prime}$ & 6 \\
GapmeR AQP1 & $5^{\prime}-+\mathrm{T}+\mathrm{G}+\mathrm{T}$ CAG AGT GTC $+\mathrm{T}+\mathrm{A}+\mathrm{C}-3$, & 6 \\
\hline
\end{tabular}

Supplementary Table 2. Primer sequences used for cloning of AQP1 and the validation of different genes by qPCR. hsa: Homo sapiens. mmu: Mus musculus.

\begin{tabular}{|c|c|c|}
\hline AQP1 cloning & Primer forward & Primer reverse \\
\hline Nested PCR & $5^{\prime}$ - ATG GCC AGC GAG TTC AAG - 3' & 5' - CTA TTT GGG CTT CAT CTC C - 3' \\
\hline \multirow{2}{*}{ Reverse PCR } & 5' - AAA CTT AAG CTT GCC GCC ATG GCC & 5' - CTA GAC TCG AGC TAT TTG GGC TTC \\
\hline & AGC GAG TTC AAG - 3', & ATC TCC -3 \\
\hline Gene & Primer forward & Primer reverse \\
\hline$\beta$-actin (hsa, mmu) & $5^{\prime}$ - TCA AGA TCA TTG CTC CTC CTG AG - 3' & $5^{\prime}-$ TCC TGC TTG CTG ATC CAC ATC - 3' \\
\hline AQP1 (hsa) & 5' - ACC TCC TGG CTA TTG ACT ACA C - 3' & 5' - GGT TGC TGA AGT TGT GTG TGA TC - 3' \\
\hline AQP1 (mmu) & 5' - ACT TGG CCG CAA TGA CCT GG - 3' & 5' - CAG AGT GCC AAT GAT CTC AAT GC - 3' \\
\hline p53 (hsa) & $5^{\prime}-$ AGC CAC CTG AAG TCC AAA AAG - 3' & $5^{\prime}$ - CCC TTC TGT CTT GAA CAT GAG - ${ }^{\prime}$ \\
\hline
\end{tabular}




\section{Supplementary Figures}

Donor \#1

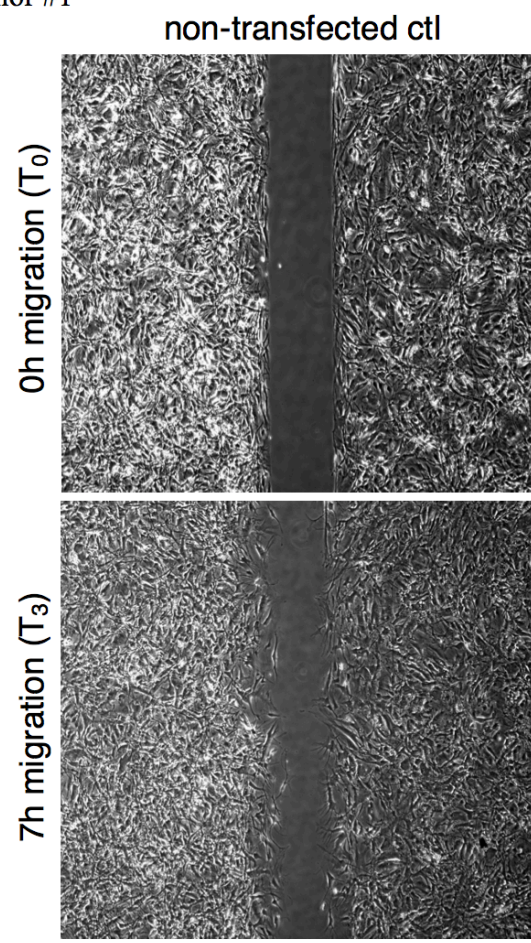

GapmeR neg. ctl
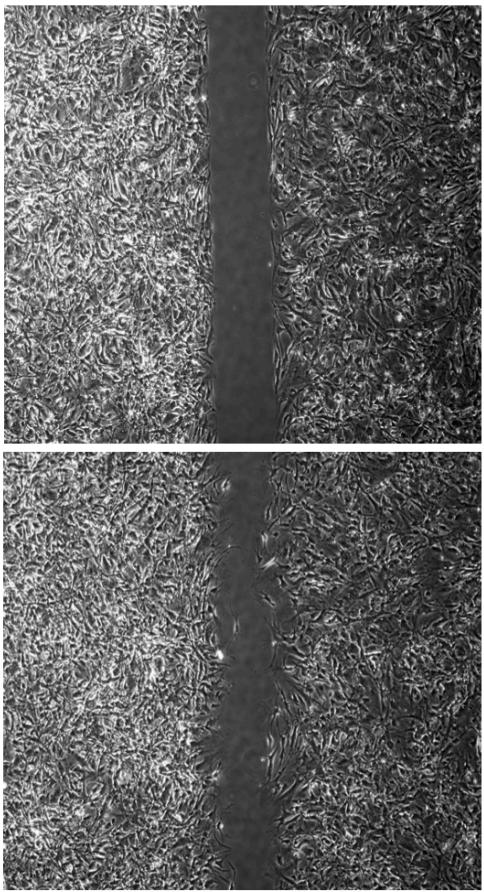

GapmeR AQP1
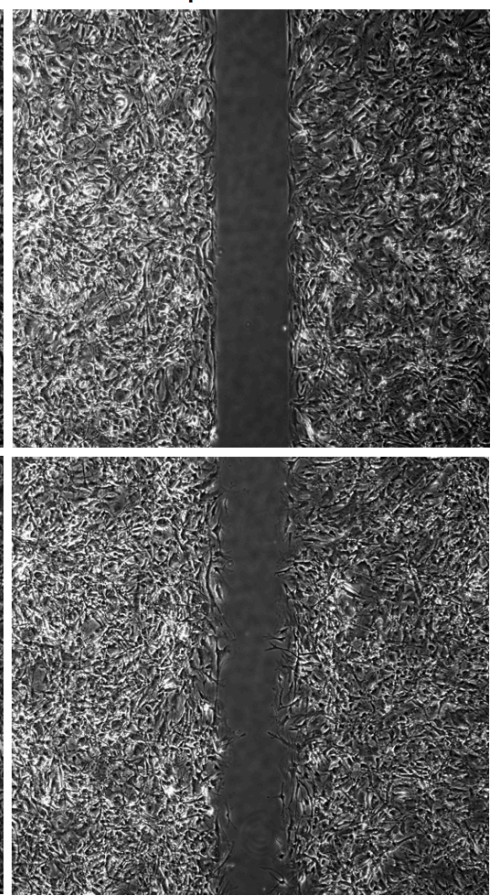

Donor \#2
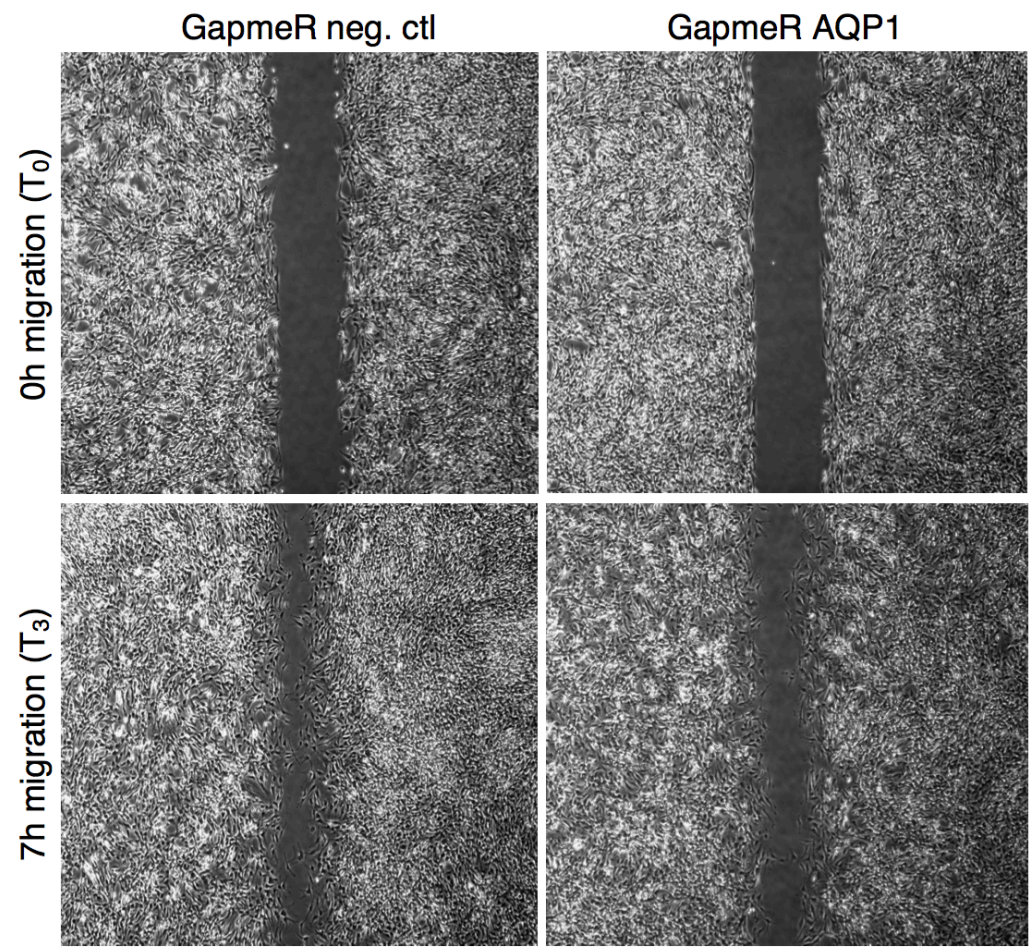

Supplementary Figure 1. Representative pictures of HPASMC (donors \#1 and \#2) migrated for $7 \mathrm{~h}$ in normoxia after transfection with GapmeR targeting AQP1 compared to non-transfected or GapmeR negative control transfected cells. 


\subsection{Supplementary Material}

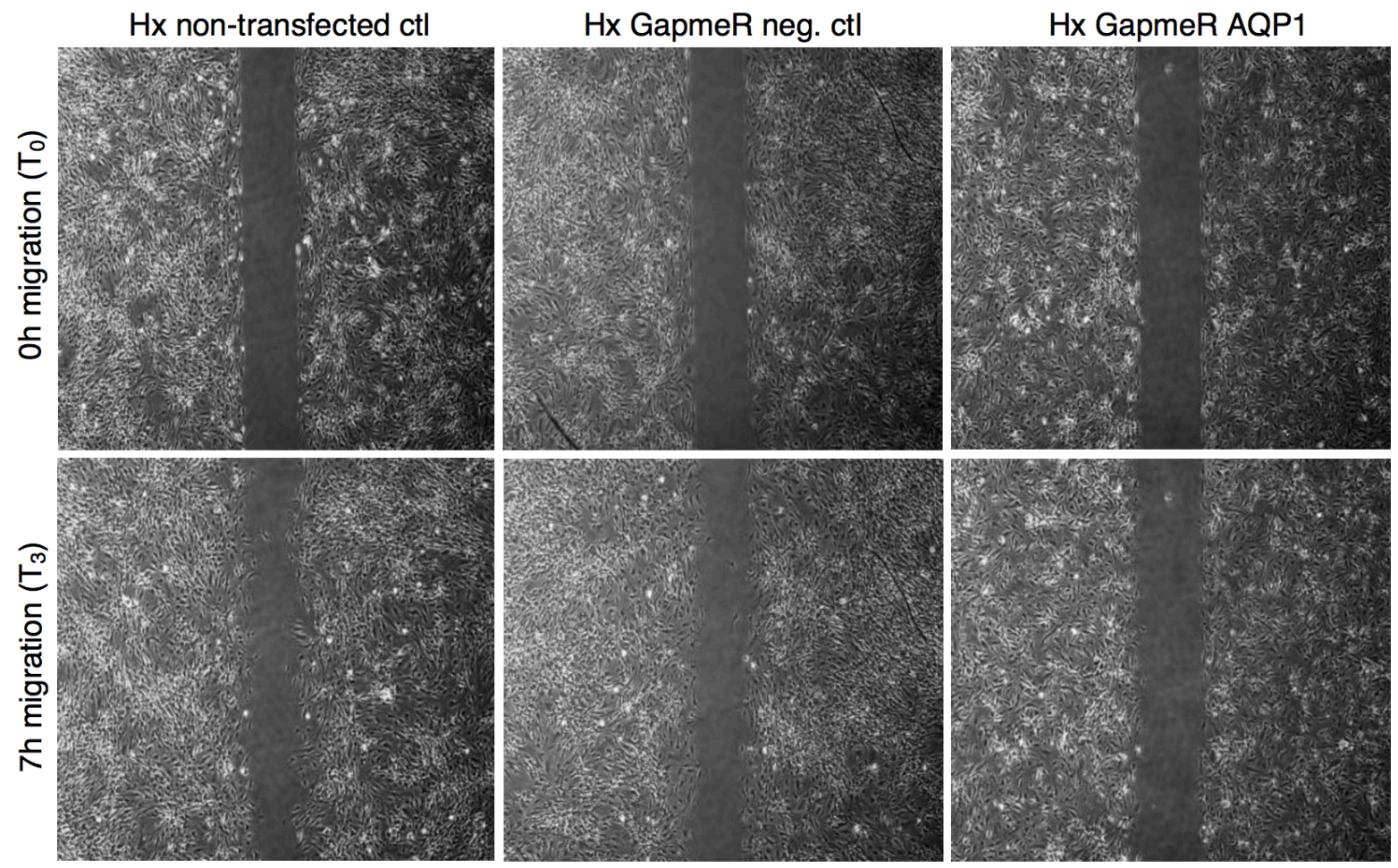

Supplementary Figure 2. Representative pictures of HPASMC migrated for $7 \mathrm{~h}$ in hypoxia (Hx) after transfection with GapmeR targeting AQP1 compared to non-transfected or GapmeR negative control transfected cells.

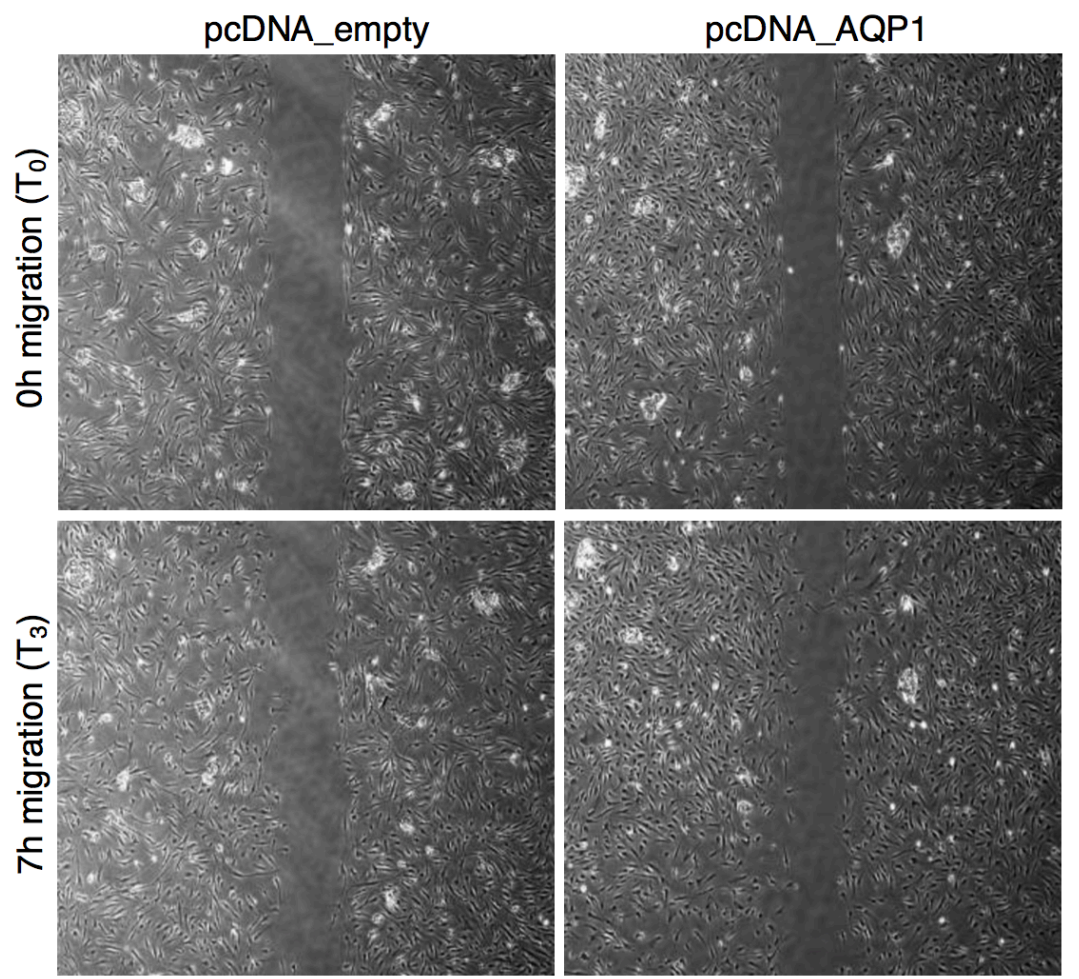

Supplementary Figure 3. Representative pictures of HPASMC migrated for $7 \mathrm{~h}$ after transfection with AQP1 overexpressing vector (pcDNA_AQP1) compared to empty control transfected cells (pcDNA_empty). 
A

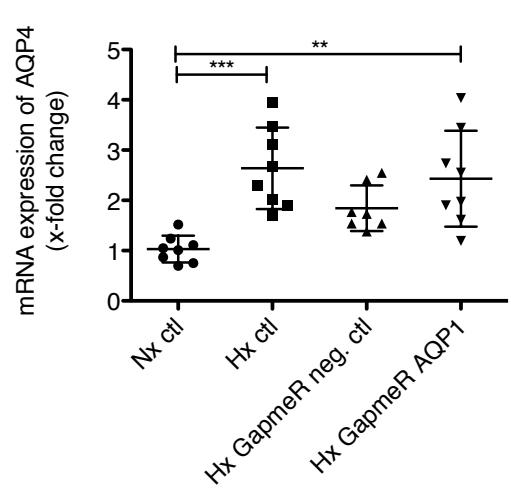

\section{B}

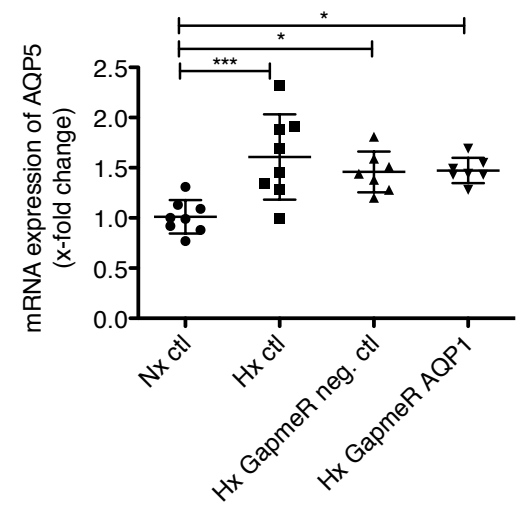

Supplementary Figure 4. Lung mRNA expression of AQP2-5 in the mouse model of hypoxia-induced PH. Effect of hypoxia and GapmeR treatment on AQP4 (a) and AQP5 (b) in lung homogenates measured by qPCR. The levels of AQP2 and AQP3 have not been added since both revealed poor $\mathrm{C}_{t}$ values $(>32) . n=7-8$. Statistical analysis by one-way ANOVA with Tukey post hoc test $\left({ }^{*} p<0.05,{ }^{* *} p<0.01,{ }^{* * *} p<0.001\right)$. 


\section{SYNTHESIS}

\subsection{MAIN FINDINGS AND IMPLICATIONS}

AQP1 is known to be induced by hypoxia which itself might be both a causative factor for and a consequence of elevated pulmonary pressure. Of interest, however, the physiological consequence of the manipulation of AQP1 expression has not been described in the context of hypoxia-induced PH so far and our study provides the first evidence for a functional role of AQP1 in the disease by employing an intervention model in mice with hypoxia-induced PH. In this study, we confirmed previous findings showing that (i) hypoxia increases the expression of AQP1 both in vitro, most prominently in HPASMC, and in vivo in the hypoxiainduced mouse model of $\mathrm{PH} .{ }^{71}$ In addition, we demonstrated that (ii) manipulation of AQP1 affects the expression of the tumour suppressor gene p53 in HPASMC with decreased levels after hypoxic exposure and increased levels after silencing of AQP1 by a novel chimeric antisense oligonucleotide technology (GapmeRs). p53 has pro-apoptotic and growthsuppressive effects by holding the cell cycle at the G1/S regulation point. ${ }^{40}$ Therefore, high p53 induces apoptosis and cell cycle arrest which is in agreement with the functional data seen in HPASMC: Here, (iii) AQP1 influences the functional profile of pulmonary vascular cells via controlling a migratory, pro-proliferative, and anti-apoptotic phenotype of HPASMC as assessed by silencing and overexpression experiments. Inhibition of AQP1 via GapmeRs decreased the migratory and proliferative response while increasing apoptosis and AQP1 overexpression resulted in enhanced proliferation and migration. By employing the (iv) hypoxia-induced PH mouse model, our data indicate that the pharmacological use of GapmeRs to target AQP1 reverses hypoxia-induced elevated pulmonary pressure and might treat vascular remodelling since planimetric analysis of the Fulton index $[\mathrm{RV} /(\mathrm{LV}+\mathrm{S})]^{81}$ revealed a decrease in right ventricular hypertrophy in GapmeR AQP1 treated hypoxic mice.

With this doctoral thesis, I have extensively addressed the expression and function of AQP1 in the context of hypoxia-induced PH. Our findings offer new insights and represent the first direct link between $\mathrm{PH}$ and AQP1, possibly providing an interesting novel target to address $\mathrm{PH}$. We present data showing that AQP1 has an important functional role in the development of pulmonary vascular remodelling in hypoxia-induced PH. Since vascular remodelling is due to enhanced proliferation of pulmonary artery smooth muscle cells and is currently not 
sufficiently addressed by PH therapies, these data have implications both for our pathogenetic understanding and novel therapeutic approaches.

\subsection{Limitations}

The research addressed in this thesis faces several limitations that need to be considered. A major limitation of the present work is the absence of a mechanistic explanation how AQP1 executes its function in the context of hypoxia-induced PH. The exact mechanism remains elusive and it will be difficult, in general, to unravel the underlying molecular mechanisms that act at the interface of hypoxia, AQP1, and PH.

We suggest that AQP1 might act through interaction with the tumour suppressor $\mathrm{p} 53$, which has repeatedly been associated with the development of pulmonary hypertension. This connection is well elaborated but, whether, further upstream, other processes might be additionally involved, is part of an interesting hypothesis but remains unclear to date. Jacquin et al. showed that $\mathrm{p} 53$ is found downregulated in the monocrotaline model of $\mathrm{PH}^{41}$ Moreover, inactivation of p53 alone was sufficient to induce the development of experimental $\mathrm{PH}$ and another study demonstrated that exogenous NO has an inhibitory effect on smooth muscle cell proliferation via induction of p53 and p21. ${ }^{42,43}$ Additionally, enhanced p53 mRNA as well as protein levels were found after silencing of AQP3 with shRNA in a non-small cell lung cancer (NSCLC) model, which was accompanied with suppressed tumour proliferation. AQP3 knockdown reduced cellular glycerol content (AQP3 is a aquaglyceroporin) and mitochondrial ATP formation, which, together with a reduction in PCNA levels, might contribute to the inhibitive effect on tumour proliferation. ${ }^{74}$

In the light of other findings that tried to tie AQP1 function to several stimuli, Legget et al. showed that hypoxia induces intracellular calcium concentration in arterial smooth muscle cells, which, in turn, results in increased AQP1 protein levels and cell migration. ${ }^{71} \mathrm{Al}$ Ghouleh et al. highlighted the importance of AQP1 for the vascular smooth muscle phenotype by demonstrating that reactive oxygen species (ROS) are channelled via AQP $1{ }^{75}$ To address this issue, we performed $\mathrm{H}_{2} \mathrm{O}_{2}$ experiments on the role of ROS. These experiments have not shown evidence for a pathogenetic role of ROS in our setting (Fig. 1-3). Considering the results from Al Ghouleh et al. that showed an effect of ROS on smooth muscle cell hypertrophy, however, without affecting proliferation, this is not an unexpected finding. 

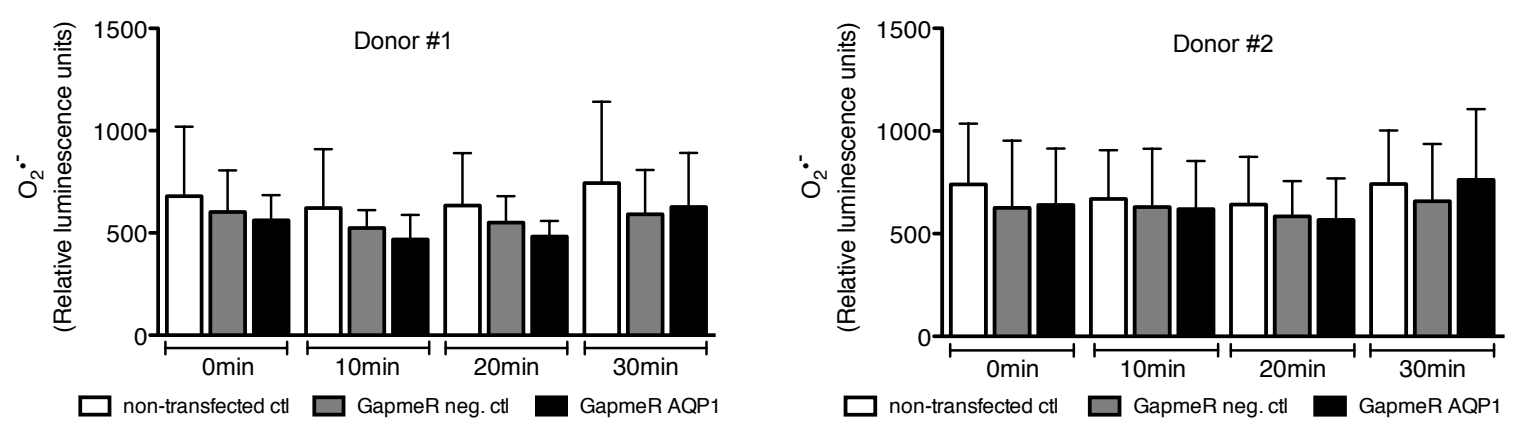

Figure 1. Stimulation with exogenous $\mathrm{H}_{2} \mathrm{O}_{2}(50 \mu \mathrm{mol} / \mathrm{L})$ for $24 \mathrm{~h}$ does not affect $\mathrm{O}_{2}{ }^{--}$production in both donors of GapmeR transfected HPASMC. Adopted L-012 (400 $\mu \mathrm{mol} / \mathrm{L})$ chemiluminescence assay was performed immediately ( $0 \mathrm{~min}$ ) or after $10 \mathrm{~min}, 20 \mathrm{~min}$, and $30 \mathrm{~min}$ as described by Al Ghouleh et al. ${ }^{75} n=3$. Statistical analysis by Friedman test with Dunns post hoc test.

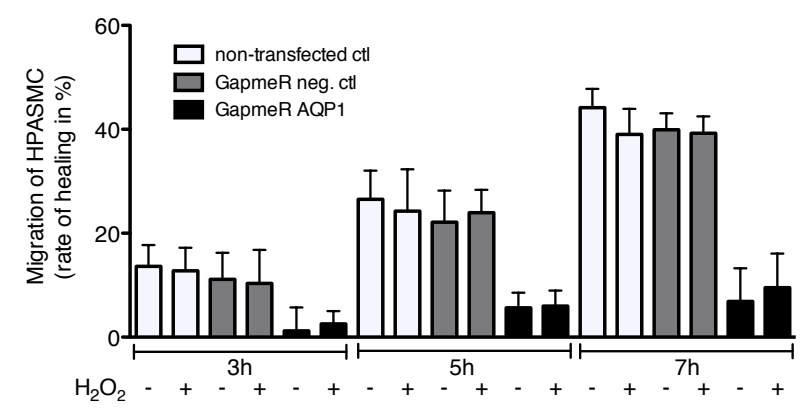

Figure 2. Stimulation with exogenous $\mathrm{H}_{2} \mathrm{O}_{2} \quad(50$ $\mu \mathrm{mol} / \mathrm{L}$ ) for $24 \mathrm{~h}$ does not have an effect on migration in GapmeR transfected HPASMC. Migration was assessed after $3 \mathrm{~h}, 5 \mathrm{~h}$, and $7 \mathrm{~h} . n=3$. Statistical analysis by Friedman test with Dunns post hoc test.

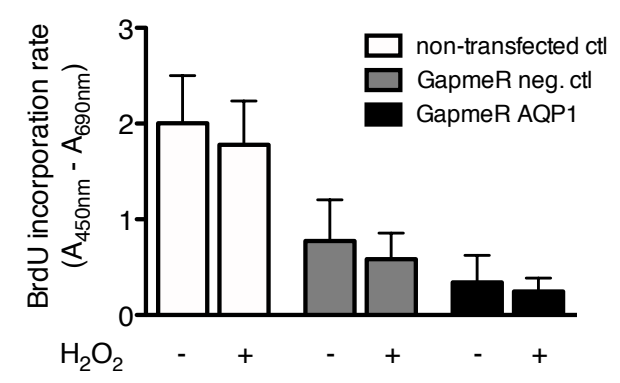

Figure 3. Stimulation with exogenous $\mathrm{H}_{2} \mathrm{O}_{2}(50$ $\mu \mathrm{mol} / \mathrm{L}$ ) for $24 \mathrm{~h}$ does not have an effect on proliferation in GapmeR transfected HPASMC. $n=5$. Statistical analysis by Friedman test with Dunns post hoc test.

Furthermore, a study investigated the role of the C-terminal tail of AQP1 on migration and proliferation since the exact mechanism by which AQP1 facilitates these two processes remains unclear. ${ }^{72}$ In summary, the authors showed that the $\mathrm{C}$-terminus is required since its deletion in AQP1 overexpressing rat smooth muscle cells abolished the effect on both migration and proliferation. As a consequence, they proposed that AQP1 mediates its function via factors or proteins associated with the C-terminal tail, however, not offering an exact mechanism and only being vague.

Moreover, microarray data further revealed alterations in several proliferating-regulating genes suggesting that AQP1 modifies the expression of key cell cycle proteins. ${ }^{76}$ Although this breakthrough paper revealed a rather tight connection between AQP1 and its role in proliferation by affecting cell cycle progression, it also fails to unravel the exact mechanistic insights on how AQP1 executes its function in this context. In consideration of this work and 
a recently published paper by our group on the role of lncRNA MALAT1 in smooth muscle cell proliferation, ${ }^{39}$ we tried to address a similar setting via measuring mRNA levels of cyclindependent kinase inhibitors (CDKi: p15, p16, p18, p19, p21, p27, and p57), cyclin D1 and E1, and NFK-B1, respectively, in HPASMC transfected with GapmeR targeting AQP1. Only the expression levels of cyclin E1 were significantly altered (Fig. 4). However, as a representative protein of the $\mathrm{S}$ phase in the cell cycle, we expected it to be downregulated when AQP1 is silenced. This indicates that AQP1 does not, at least in our setup, act through CDKi or selected cyclins.

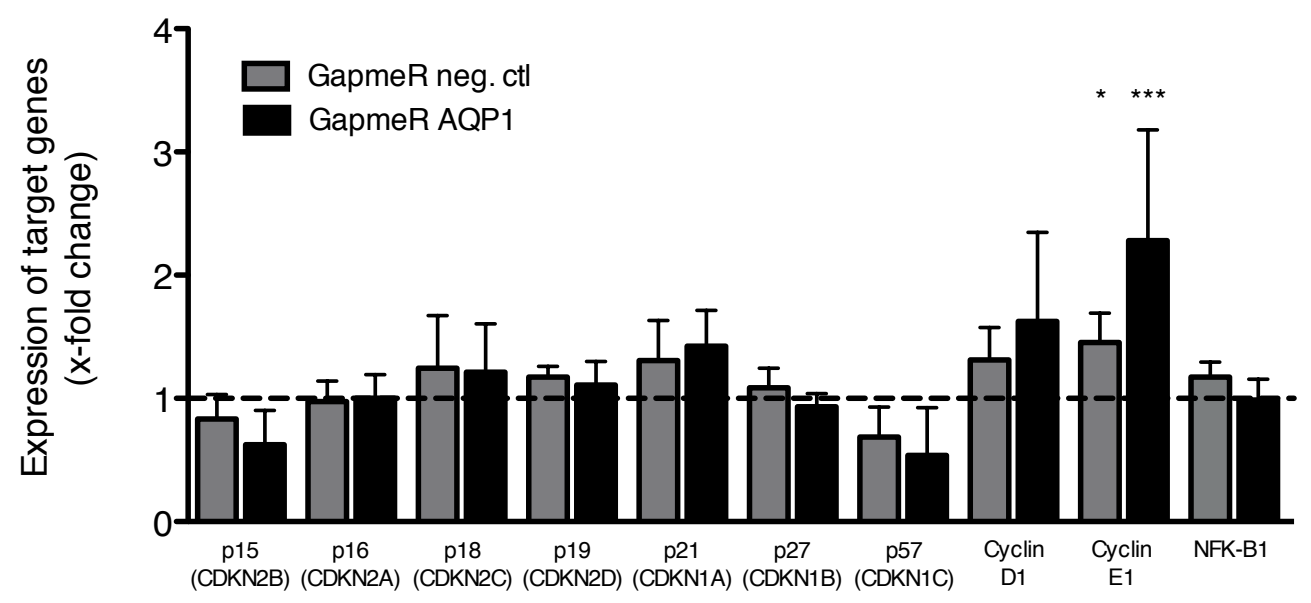

Figure 4. mRNA expression of selected cyclin-dependent kinase inhibitors (CDKi), cyclin D1 and E1, and NFK-B1 in GapmeR AQP1 transfected HPASMC. The expression levels of non-transfected control cells were set to 1 (shown as dashed line). $n=5$. Statistical analysis by one-way ANOVA with Tukey post hoc test $\left({ }^{*} p<\right.$ 0.05 compared to GapmeR AQP1 (cyclin E1), ${ }^{* * *} p<0.001$ compared to non-transfected control cells).

All these studies and additional experiments try to explain the AQP1-mediated mechanism in the context of hypoxia-induced $\mathrm{PH}$, even though without being a transcription factor. However, experimental proofs were beyond the scope of this work, but, nevertheless, are a prominent issue that should be subjected to follow-up in a further project. Despite the fact that the exact molecular players providing the mechanistic interaction have not been unravelled so far, our experiments highly suggest a causal link between hypoxia, AQP1 and PH.

Animal models used to investigate $\mathrm{PH}$, although they support several mechanisms identified in cell culture work, are of limited value and only partially mimic human disease. ${ }^{82}$ However, the hypoxia-induced mouse model is one of the best-established models for PH and, in the context of AQP1 that is strongly driven by hypoxic conditions, represents a suitable in vivo model. Nevertheless, another limitation of our study is the near absence of right ventricular hypertrophy in the hypoxic GapmeR control group. This might be explained by a combination 


\subsection{Limitations}

of methodical limitations of applied morphometric analysis and the relatively high biological variation, which was observed in our hypoxia-induced PH mouse model. Although this mouse model is frequently used, it is supposed to be a mild one in terms of RVP increase, RVH, and pulmonary vascular remodelling. ${ }^{83}$ Repeated i.p. injections of GapmeRs lead to a systemic knockout of AQP1 in the mouse model and not much is known about the pharmacokinetics of GapmeRs. It might have been beneficial to apply more often or even locally and specifically in the lungs, e.g. through a nebulizer. However, RVP was significantly elevated in this group after hypoxic exposure. Newly established animal models for hypoxia-induced PH, e.g. the new gold standard Sugen/hypoxia model, ${ }^{84}$ were shown to induce a more pronounced pathological cardiorespiratory phenotype and are more frequently used nowadays. In this context, unfortunately, we were not able to provide data on immunohistochemistry (IHC) that may have further strengthened our hypothesis about the involvement of AQP1 in vascular remodelling in hypoxia-induced $\mathrm{PH}$ where one would expect reduced vascular remodelling in the GapmeR AQP1 treated hypoxic animals. Using IHC for established targets of smooth muscle cell proliferation (e.g. $\alpha$-smooth muscle actin) and markers for endothelial (e.g. von Willebrand factor) and adventitial layer (e.g. collagen), the degree of vascular remodelling in the pulmonary vessels could have been assessed. The infeasibility on conducting IHC was due to technical and methodological restrictions.

Another issue that needs to be dealt with is the lack of reduction in apoptosis in AQP1 overexpressing HPASMC. Contrary to GapmeR AQP1 transfected cells, no effects were observed on the spontaneous rate of apoptosis in these cells. While these data suggest that overexpression of AQP1 has no effect on spontaneous apoptosis of vascular smooth muscle cells, one cannot exclude that AQP1 alters resistance of cells to apoptosis when exposed to strong inducers of cell death. Such stimuli might include camptothecin (CPT), which addresses the intrinsic apoptotic pathway via inhibition of topoisomerase I, and Fas ligand (FasL), which addresses the extrinsic apoptotic pathway via binding to plasma membrane spanning death receptors like Fas receptor (FasR).

\subsection{OUTLOOK}

As extensively discussed in chapter 3.2 'Limitations', a big goal would be to identify the underlying AQP1-mediated molecular mechanisms that lead to pulmonary vascular 
remodelling. Furthermore, researchers are very interested in finding new specific inhibitors, which would make it easier to investigate the direct function of AQPs in general. So far, studies of the phenotype of AQP-knockout mice have provided most of the information on AQP physiology and function. Compelling evidence from studies using AQP-knockout mice and from humans with AQPs loss-of-function mutations suggest that AQPs are important research tools and drug targets for the treatment of human diseases, having broad implementations not only in the field of pulmonology but also in different clinical therapies such as nephrology, neurology, oncology, and ophthalmology. The identification of AQP modulators, however, has turned out to be unexpectedly challenging and the poor drugability of AQPs may be, among others, due to the small size of the functional AQP monomer and its very small pore diameter, which prevents the access of small molecules. As long as no suitable AQP inhibitors are discovered, alternative strategies are required such as the use of novel antisense oligonucleotides like GapmeRs or even the new promising targeted gene editing tool CRISPR/Cas9 system, which has generated considerable excitement in the scientific community. On grounds of the above and based on my studies, one should consider the following additional questions that should be addressed by further experiments: (i) Does the inhibition of AQP1 result in reversal of the vascular remodelling of pulmonary arterial vessels, e.g. by employing IHC? (ii) Is the application of GapmeRs to silence AQP1 a feasible clinical approach to deliver and to influence targeted cells, e.g. in the lung? These in vivo experiments will clarify the role of AQP1 in the pathogenesis of $\mathrm{PH}$ and address the question whether GapmeR directed against AQP1 can be used as a novel and promising drug to treat hypoxia-induced $\mathrm{PH}$. 


\section{REFERENCES}

1. McLaughlin VV, Davis M, Cornwell W. Pulmonary arterial hypertension. Curr Probl Cardiol. 2011;36:461-517

2. Rubin LJ. Primary pulmonary hypertension. N Engl J Med. 1997;336:111-117

3. Romberg von E. Über sklerose der lungenarterie. Dtsch Arch Klin Med. 18911892;48:197-206

4. Humbert M, Morrell NW, Archer SL, Stenmark KR, MacLean MR, Lang IM, Christman BW, Weir EK, Eickelberg O, Voelkel NF, Rabinovitch M. Cellular and molecular pathobiology of pulmonary arterial hypertension. J Am Coll Cardiol. 2004;43:13S-24S

5. Humbert M, Sitbon O, Chaouat A, Bertocchi M, Habib G, Gressin V, Yaici A, Weitzenblum E, Cordier JF, Chabot F, Dromer C, Pison C, Reynaud-Gaubert M, Haloun A, Laurent M, Hachulla E, Simonneau G. Pulmonary arterial hypertension in france: Results from a national registry. Am J Respir Crit Care Med. 2006;173:10231030

6. Simonneau G, Gatzoulis MA, Adatia I, Celermajer D, Denton C, Ghofrani A, Gomez Sanchez MA, Kumar RK, Landzberg M, Machado RF, Olschewski H, Robbins IM, Souza R. [updated clinical classification of pulmonary hypertension]. Turk Kardiyol Dern Ars. 2014;42 Supp1 1:45-54

7. Foshat M, Boroumand N. The evolving classification of pulmonary hypertension. Arch Pathol Lab Med. 2017

8. Schermuly RT, Ghofrani HA, Wilkins MR, Grimminger F. Mechanisms of disease: Pulmonary arterial hypertension. Nat Rev Cardiol. 2011;8:443-455

9. Semenza GL. Oxygen sensing, homeostasis, and disease. $N$ Engl J Med. 2011;365:537-547

10. Agostoni P, Cattadori G, Bussotti M, Apostolo A. Cardiopulmonary interaction in heart failure. Pulm Pharmacol Ther. 2007;20:130-134

11. Dempsey JA, Veasey SC, Morgan BJ, O'Donnell CP. Pathophysiology of sleep apnea. Physiol Rev. 2010;90:47-112

12. Gilreath JA, Stenehjem DD, Rodgers GM. Diagnosis and treatment of cancer-related anemia. Am J Hematol. 2014;89:203-212

13. Kent BD, Mitchell PD, McNicholas WT. Hypoxemia in patients with copd: Cause, effects, and disease progression. Int J Chron Obstruct Pulmon Dis. 2011;6:199-208

14. Humbert M, Sitbon O, Simonneau G. Treatment of pulmonary arterial hypertension. $N$ Engl J Med. 2004;351:1425-1436 
15. Huber LC, Bye H, Brock M, Swiss Society of Pulmonary H. The pathogenesis of pulmonary hypertension--an update. Swiss Med Wkly. 2015;145:w14202

16. Tuder RM, Marecki JC, Richter A, Fijalkowska I, Flores S. Pathology of pulmonary hypertension. Clin Chest Med. 2007;28:23-42, vii

17. Dumas JP, Bardou M, Goirand F, Dumas M. Hypoxic pulmonary vasoconstriction. Gen Pharmacol. 1999;33:289-297

18. Stenmark KR, Fagan KA, Frid MG. Hypoxia-induced pulmonary vascular remodeling: Cellular and molecular mechanisms. Circ Res. 2006;99:675-691

19. Ward JP, McMurtry IF. Mechanisms of hypoxic pulmonary vasoconstriction and their roles in pulmonary hypertension: New findings for an old problem. Curr Opin Pharmacol. 2009;9:287-296

20. Soubrier F, Chung WK, Machado R, Grunig E, Aldred M, Geraci M, Loyd JE, Elliott CG, Trembath RC, Newman JH, Humbert M. Genetics and genomics of pulmonary arterial hypertension. J Am Coll Cardiol. 2013;62:D13-21

21. Perros F, Dorfmuller P, Humbert M. Current insights on the pathogenesis of pulmonary arterial hypertension. Semin Respir Crit Care Med. 2005;26:355-364

22. Ghofrani HA, Voswinckel R, Reichenberger F, Weissmann N, Schermuly RT, Seeger W, Grimminger F. Hypoxia- and non-hypoxia-related pulmonary hypertension established and new therapies. Cardiovasc Res. 2006;72:30-40

23. Godinas L, Guignabert C, Seferian A, Perros F, Bergot E, Sibille Y, Humbert M, Montani D. Tyrosine kinase inhibitors in pulmonary arterial hypertension: A doubleedge sword? Semin Respir Crit Care Med. 2013;34:714-724

24. Bai Y, Wang HM, Liu M, Wang Y, Lian GC, Zhang XH, Kang J, Wang HL. 4-chlorodl-phenylalanine protects against monocrotalineinduced pulmonary vascular remodeling and lung inflammation. Int J Mol Med. 2014;33:373-382

25. Sitbon O, McLaughlin VV, Badesch DB, Barst RJ, Black C, Galie N, Humbert M, Rainisio M, Rubin LJ, Simonneau G. Survival in patients with class iii idiopathic pulmonary arterial hypertension treated with first line oral bosentan compared with an historical cohort of patients started on intravenous epoprostenol. Thorax. 2005;60:1025-1030

26. Opitz CF, Ewert R, Kirch W, Pittrow D. Inhibition of endothelin receptors in the treatment of pulmonary arterial hypertension: Does selectivity matter? Eur Heart J. 2008;29:1936-1948

27. Velayati A, Valerio MG, Shen M, Tariq S, Lanier GM, Aronow WS. Update on pulmonary arterial hypertension pharmacotherapy. Postgrad Med. 2016;128:460-473

28. Barst RJ, Rubin LJ, Long WA, McGoon MD, Rich S, Badesch DB, Groves BM, Tapson VF, Bourge RC, Brundage BH, Koerner SK, Langleben D, Keller CA, Murali S, Uretsky BF, Clayton LM, Jobsis MM, Blackburn SD, Shortino D, Crow JW, Primary Pulmonary Hypertension Study G. A comparison of continuous intravenous 
epoprostenol (prostacyclin) with conventional therapy for primary pulmonary hypertension. $N$ Engl J Med. 1996;334:296-301

29. Wort SJ, Woods M, Warner TD, Evans TW, Mitchell JA. Endogenously released endothelin-1 from human pulmonary artery smooth muscle promotes cellular proliferation: Relevance to pathogenesis of pulmonary hypertension and vascular remodeling. Am J Respir Cell Mol Biol. 2001;25:104-110

30. Davie N, Haleen SJ, Upton PD, Polak JM, Yacoub MH, Morrell NW, Wharton J. Et(a) and et(b) receptors modulate the proliferation of human pulmonary artery smooth muscle cells. Am J Respir Crit Care Med. 2002;165:398-405

31. Cohen AH, Hanson K, Morris K, Fouty B, McMurty IF, Clarke W, Rodman DM. Inhibition of cyclic 3'-5'-guanosine monophosphate-specific phosphodiesterase selectively vasodilates the pulmonary circulation in chronically hypoxic rats. J Clin Invest. 1996;97:172-179

32. Jernigan NL, Resta TC. Chronic hypoxia attenuates cgmp-dependent pulmonary vasodilation. Am J Physiol Lung Cell Mol Physiol. 2002;282:L1366-1375

33. Weissmann N, Voswinckel R, Tadic A, Hardebusch T, Ghofrani HA, Schermuly RT, Seeger W, Grimminger F. Nitric oxide (no)-dependent but not no-independent guanylate cyclase activation attenuates hypoxic vasoconstriction in rabbit lungs. $\mathrm{Am} \mathrm{J}$ Respir Cell Mol Biol. 2000;23:222-227

34. Gammella E, Leuenberger C, Gassmann M, Ostergaard L. Evidence of synergistic/additive effects of sildenafil and erythropoietin in enhancing survival and migration of hypoxic endothelial cells. Am J Physiol Lung Cell Mol Physiol. 2013;304:L230-239

35. Samillan V, Haider T, Vogel J, Leuenberger C, Brock M, Schwarzwald C, Gassmann M, Ostergaard L. Combination of erythropoietin and sildenafil can effectively attenuate hypoxia-induced pulmonary hypertension in mice. Pulm Circ. 2013;3:898907

36. Vaidya B, Pangallo M, Ruffenach G, Cunningham CM, Perron JC, Kolluru S, Eghbali M, Gupta V. Advances in treatment of pulmonary arterial hypertension: Patent review. Expert Opin Ther Pat. 2017

37. Machado RD, Eickelberg O, Elliott CG, Geraci MW, Hanaoka M, Loyd JE, Newman JH, Phillips JA, 3rd, Soubrier F, Trembath RC, Chung WK. Genetics and genomics of pulmonary arterial hypertension. J Am Coll Cardiol. 2009;54:S32-42

38. Brock M, Trenkmann M, Gay RE, Michel BA, Gay S, Fischler M, Ulrich S, Speich R, Huber LC. Interleukin-6 modulates the expression of the bone morphogenic protein receptor type ii through a novel stat3-microrna cluster 17/92 pathway. Circ Res. 2009;104:1184-1191

39. Brock M, Schuoler C, Leuenberger C, Buhlmann C, Haider TJ, Vogel J, Ulrich S, Gassmann M, Kohler M, Huber LC. Analysis of hypoxia-induced noncoding rnas reveals metastasis-associated lung adenocarcinoma transcript 1 as an important regulator of vascular smooth muscle cell proliferation. Exp Biol Med (Maywood). 2017;242:487-496 
40. Suzuki K, Matsubara H. Recent advances in p53 research and cancer treatment. $J$ Biomed Biotechnol. 2011;2011:978312

41. Jacquin S, Rincheval V, Mignotte B, Richard S, Humbert M, Mercier O, LondonoVallejo A, Fadel E, Eddahibi S. Inactivation of p53 is sufficient to induce development of pulmonary hypertension in rats. PLoS One. 2015;10:e131940

42. Mizuno S, Bogaard HJ, Kraskauskas D, Alhussaini A, Gomez-Arroyo J, Voelkel NF, Ishizaki T. P53 gene deficiency promotes hypoxia-induced pulmonary hypertension and vascular remodeling in mice. Am J Physiol Lung Cell Mol Physiol. 2011;300:L753-761

43. Mizuno S, Kadowaki M, Demura Y, Ameshima S, Miyamori I, Ishizaki T. P42/44 mitogen-activated protein kinase regulated by $\mathrm{p} 53$ and nitric oxide in human pulmonary arterial smooth muscle cells. Am J Respir Cell Mol Biol. 2004;31:184-192

44. Harris HW, Jr., Strange K, Zeidel ML. Current understanding of the cellular biology and molecular structure of the antidiuretic hormone-stimulated water transport pathway. J Clin Invest. 1991;88:1-8

45. Benga G, Popescu O, Pop VI, Borza V, Ildiko M. Water permeability of human erythrocytes. Identification of membrane proteins involved in water transport. Eur. $J$. Cell Biol. 1986;41:252-262

46. Benga G, Popescu O, Pop VI, Holmes R. P-(chloromercuri)benzenesulfonate binding by membranes proteins and the inhibition of water transport in human erythrocytes. Biochemistry. 1986; 7:807-818

47. Denker BM, Smith BL, Kuhaida FP, Agre P. Identification, purification, and partial characterization of a novel $\mathrm{mr} 28,000$ integral membrane protein from erythrocytes and renal tubules. J Biol Chem. 1988;263:15634-15642

48. Preston GM, Carroll TP, Guggino WB, Agre P. Appearance of water channels in xenopus oocytes expressing red cell chip28 protein. Science. 1992;256:385-387

49. Preston GM, Agre P. Isolation of the cdna for erythorcyte integral membrane protein of 28 kilodaltons: Member of an ancient channel family. P Natl Acad Sci USA. 1991;88:11110-11114

50. Agre P, Sasaki S, Chrispeels MJ. Aquaporins: A family of membrane water channels. Am. J. Physiol. 1993;265:F461

51. Benga G. The first discovered water channel protein, later called aquaporin 1: Molecular characteristics, functions and medical implications. Mol Aspects Med. 2012;33:518-534

52. Kruse E, Uehlein N, Kaldenhoff R. The aquaporins. Genome Biol. 2006;7:206

53. Verkman AS. Aquaporins in clinical medicine. Annu Rev Med. 2012;63:303-316

54. Kreida S, Tornroth-Horsefield S. Structural insights into aquaporin selectivity and regulation. Curr Opin Struct Biol. 2015;33:126-134 
55. King LS, Kozono D, Agre P. From structure to disease: The evolving tale of aquaporin biology. Nat Rev Mol Cell Biol. 2004;5:687-698

56. Ishibashi K, Hara S, Kondo S. Aquaporin water channels in mammals. Clin Exp Nephrol. 2009;13:107-117

57. Madeira A, Moura TF, Soveral G. Detecting aquaporin function and regulation. Front Chem. 2016;4:3

58. $\mathrm{Fu} \mathrm{D,} \mathrm{Lu} \mathrm{M.} \mathrm{The} \mathrm{structural} \mathrm{basis} \mathrm{of} \mathrm{water} \mathrm{permeation} \mathrm{and} \mathrm{proton} \mathrm{exclusion} \mathrm{in}$ aquaporins. Mol Membr Biol. 2007;24:366-374

59. Verkman AS, Mitra AK. Sturcutre and function of aquaporin water channels. Am.j. Physiol. Renal Physiol. 2000;278:F13-F28

60. Verkman AS, Anderson MO, Papadopoulos MC. Aquaporins: Important but elusive drug targets. Nat Rev Drug Discov. 2014;13:259-277

61. Gonen T, Walz T. The structure of aquaporins. Q Rev Biophys. 2006;39:361-396

62. Tajkhorshid E, Nollert P, Jensen MO, Miercke LJ, O'Connell J, Stroud RM, Schulten $\mathrm{K}$. Control of the selectivity of the aquaporin water channel family by global orientational tuning. Science. 2002;296:525-530

63. Sui H, Han BG, Lee JK, Walian P, Jap BK. Structural basis of water-specific transport through the aqp1 water channel. Nature. 2001;414:872-878

64. Zhang R, van Hoek AN, Biwersi J, Verkman AS. A point mutation at cysteine 189 blocks the water permeability of rat kidney water channel chip28k. Biochemistry. 1993;32:2938-2941

65. Preston GM, Jung JS, Guggino WB, Agre P. The mercury-sensitive residue at cysteine 189 in the chip28 water channel. J Biol Chem. 1993;268:17-20

66. Agre P. The aquaporin water channels. Proc Am Thorac Soc. 2006;3:5-13

67. Aggarwal NR, Chau E, Garibaldi BT, Mock JR, Sussan T, Rao K, Rao K, Menon AG, D'Alessio FR, Damarla M, Biswal S, King LS, Sidhaye VK. Aquaporin 5 regulates cigarette smoke induced emphysema by modulating barrier and immune properties of the epithelium. Tissue Barriers. 2013;1:e25248

68. Calero C, Lopez-Campos JL, Izquierdo LG, Sanchez-Silva R, Lopez-Villalobos JL, Saenz-Coronilla FJ, Arellano-Orden E, Montes-Worboys A, Echevarria M. Expression of aquaporins in bronchial tissue and lung parenchyma of patients with chronic obstructive pulmonary disease. Multidiscip Respir Med. 2014;9:29

69. She J, Bi J, Tong L, Song Y, Bai C. New insights of aquaporin 5 in the pathogenesis of high altitude pulmonary edema. Diagn Pathol. 2013;8:193

70. Abreu-Rodriguez I, Sanchez Silva R, Martins AP, Soveral G, Toledo-Aral JJ, LopezBarneo J, Echevarria M. Functional and transcriptional induction of aquaporin-1 gene by hypoxia; analysis of promoter and role of hif-1alpha. PLoS One. 2011;6:e28385 
71. Leggett K, Maylor J, Undem C, Lai N, Lu W, Schweitzer K, King LS, Myers AC, Sylvester JT, Sidhaye V, Shimoda LA. Hypoxia-induced migration in pulmonary arterial smooth muscle cells requires calcium-dependent upregulation of aquaporin 1 . Am J Physiol Lung Cell Mol Physiol. 2012;303:L343-353

72. Lai N, Lade J, Leggett K, Yun X, Baksh S, Chau E, Crow MT, Sidhaye V, Wang J, Shimoda LA. The aquaporin $1 \mathrm{c}$-terminal tail is required for migration and growth of pulmonary arterial myocytes. Am J Respir Cell Mol Biol. 2014;50:1010-1020

73. Saadoun S, Papadopoulos MC, Hara-Chikuma M, Verkman AS. Impairment of angiogenesis and cell migration by targeted aquaporin-1 gene disruption. Nature. 2005;434:786-792

74. Xia H, Ma YF, Yu CH, Li YJ, Tang J, Li JB, Zhao YN, Liu Y. Aquaporin 3 knockdown suppresses tumour growth and angiogenesis in experimental non-small cell lung cancer. Exp Physiol. 2014;99:974-984

75. Al Ghouleh I, Frazziano G, Rodriguez AI, Csanyi G, Maniar S, St Croix CM, Kelley EE, Egana LA, Song GJ, Bisello A, Lee YJ, Pagano PJ. Aquaporin 1, nox1, and ask1 mediate oxidant-induced smooth muscle cell hypertrophy. Cardiovasc Res. 2013;97:134-142

76. Galan-Cobo A, Ramirez-Lorca R, Toledo-Aral JJ, Echevarria M. Aquaporin-1 plays important role in proliferation by affecting cell cycle progression. $J$ Cell Physiol. 2016;231:243-256

77. Seeliger D, Zapater C, Krenc D, Haddoub R, Flitsch S, Beitz E, Cerda J, de Groot BL. Discovery of novel human aquaporin-1 blockers. ACS Chem Biol. 2013;8:249-256

78. Straarup EM, Fisker N, Hedtjarn M, Lindholm MW, Rosenbohm C, Aarup V, Hansen HF, Orum H, Hansen JB, Koch T. Short locked nucleic acid antisense oligonucleotides potently reduce apolipoprotein $\mathrm{b}$ mrna and serum cholesterol in mice and non-human primates. Nucleic Acids Res. 2010;38:7100-7111

79. Kakiuchi-Kiyota S, Koza-Taylor PH, Mantena SR, Nelms LF, Enayetallah AE, Hollingshead BD, Burdick AD, Reed LA, Warneke JA, Whiteley LO, Ryan AM, Mathialagan N. Comparison of hepatic transcription profiles of locked ribonucleic acid antisense oligonucleotides: Evidence of distinct pathways contributing to nontarget mediated toxicity in mice. Toxicol Sci. 2014;138:234-248

80. Verkman AS. Mammalian aquaporins: Diverse physiological roles and potential clinical significance. Expert Rev Mol Med. 2008;10:e13

81. Thomas M, Docx C, Holmes AM, Beach S, Duggan N, England K, Leblanc C, Lebret C, Schindler F, Raza F, Walker C, Crosby A, Davies RJ, Morrell NW, Budd DC. Activin-like kinase 5 (alk5) mediates abnormal proliferation of vascular smooth muscle cells from patients with familial pulmonary arterial hypertension and is involved in the progression of experimental pulmonary arterial hypertension induced by monocrotaline. Am J Pathol. 2009;174:380-389

82. Gomez-Arroyo J, Saleem SJ, Mizuno S, Syed AA, Bogaard HJ, Abbate A, Taraseviciene-Stewart L, Sung Y, Kraskauskas D, Farkas D, Conrad DH, Nicolls MR, 
References

Voelkel NF. A brief overview of mouse models of pulmonary arterial hypertension: Problems and prospects. Am J Physiol Lung Cell Mol Physiol. 2012;302:L977-991

83. Maarman G, Lecour S, Butrous G, Thienemann F, Sliwa K. A comprehensive review: The evolution of animal models in pulmonary hypertension research; are we there yet? Pulm Circ. 2013;3:739-756

84. Nicolls MR, Mizuno S, Taraseviciene-Stewart L, Farkas L, Drake JI, Al Husseini A, Gomez-Arroyo JG, Voelkel NF, Bogaard HJ. New models of pulmonary hypertension based on vegf receptor blockade-induced endothelial cell apoptosis. Pulm Circ. 2012;2:434-442 



\section{APPENDIX}

\section{AbBreviations}

ANOVA

ANP

$\mathrm{AQP}(\mathrm{s})$

ASO

BMPR2

bp

BrdU

CDKi

cDNA

cGMP

CHIP28

CPT

$\mathrm{C}_{\mathrm{t}}$

ECs

Epo

ET-1

FasL

FasR

$\mathrm{H}_{2} \mathrm{O}_{2}$

$\mathrm{HgCl}_{2}$

HIF-1 $\alpha$

HPAEC

HPASMC

IHC

IL-6

i.p.

$\mathrm{kDa}$

LNA analysis of variance

atrial natriuretic peptide

aquaporin(s)

antisense oligonucleotides

bone morphogenetic protein receptor type 2

base pair

5-bromo-2-deoxyuridine

cyclin-dependent kinase inhibitors

complementary DNA

cyclic guanosine monophosphate

channel-like integral membrane protein $28 \mathrm{kDa}$

camptothecin

threshold cycle

endothelial cell

erythropoietin

endothelin-1

Fas ligand

Fas receptor

hydrogen peroxide

mercury chloride

hypoxia-inducible factor 1 alpha

human pulmonary artery endothelial cells

human pulmonary artery smooth muscle cells

immunohistochemistry

interleukin-6

intraperitoneal

kilodalton

locked nucleic acid 
lncRNA

NSCLC

MALAT1

miRNA

$\mathrm{mmHg}$

mPAP

NO

$\mathrm{PAH}$

PCNA

PDE5

$\mathrm{PH}$

qPCR

RNAi

ROS

RVH

RVP

SAP

SD

SDS-PAGE

shRNA

siRNA

SMCs

TBS-T

VEGF

WHO long non-coding RNAs

non-small cell lung cancer

metastasis-associated lung adenocarcinoma

transcript 1

microRNA

millimetre mercury

mean pulmonary arterial pressure

nitric oxide

pulmonary arterial hypertension

proliferating cell nuclear antigen

phosphodiesterase-5

pulmonary hypertension

quantitative polymerase chain reaction

RNA interference

reactive oxygen species

right ventricular hypertrophy

right ventricular pressure

systemic arterial pressure

standard deviation

sodium dodecyl sulphate polyacrylamide gel

electrophoresis

short hairpin RNA

small interfering RNA

smooth muscle cells

Tris-buffered saline containing 0.1\% Tween 20

vascular endothelial growth factor

World Health Organization 


\section{CURRICULUM VitAE}

$\begin{array}{ll}\text { Surname: } & \text { SCHUOLER } \\ \text { First Name: } & \text { Claudio } \\ \text { Date of Birth: } & 16^{\text {th }} \text { June } 1988 \\ \text { Place of Origin: } & \text { Sumvitg GR }\end{array}$

\section{Education}

07.2014-07.2017 Employment as a doctoral candidate (Dr. sc. nat.), University of Zurich and University Hospital Zurich, Department of Pulmonology

09.2012 - 04.2014 Master of Science in Biology, Human Biology, University of Zurich, Institute of Veterinary Physiology Master Thesis: "Pulmonary Hypertension and Aquaporin 1"

09.2008 - 06.2011 Bachelor of Science in Biology, University of Zurich

08.2001 - 06.2007 Gymnasium Bündner Kantonsschule Chur, Schwerpunktfach Biologie und Chemie, Ergänzungsfach Mathematik

\section{Publications with peer review process}

2017 Schuoler C, Haider TJ, Leuenberger C, Vogel J, Ostergaard L, Kwapiszewska G, Kohler M, Gassmann M, Huber LC, Brock M. (2017). Aquaporin 1 controls the functional phenotype of pulmonary smooth muscle cells in hypoxia-induced pulmonary hypertension. Basic Res Cardiol.

2016 Brock M, Schuoler C, Leuenberger C, Bühlmann C, Haider TJ, Vogel J, Ulrich S, Gassmann M, Kohler M, Huber LC. (2016) Analysis of hypoxia-induced noncoding RNAs reveals metastasis-associated lung adenocarcinoma transcript 1 as an important regulator of vascular smooth muscle cell proliferation. Exp Biol Med. 
2016 Leuenberger C, Schuoler C, Bye H, Mignan C, Rechsteiner T, Hillinger S, Opitz I, Marsland B, Faiz A, Hiemstra PS, Timens W, Camici GG, Kohler M, Huber LC, Brock M. (2016). MicroRNA-223 controls the expression of histone deacetylase 2: A novel axis in COPD. J Mol Med.

\section{National and international congress presentations}

09.2016 Poster presentation, European Respiratory Society (ERS), London, UK

08.2016 Poster presentation with award for the best poster, $12^{\text {th }}$ Symposium of the Zurich Center for Integrative Human Physiology (ZIHP), Zurich, Switzerland

03.2016 Poster presentation, 15 ${ }^{\text {th }}$ Day of Clinical Research, University Hospital Zurich, Switzerland

09.2015 Poster presentation, European Respiratory Society (ERS), Amsterdam, Netherlands

08.2015 Poster presentation, $11^{\text {th }}$ Symposium of the Zurich Center for Integrative Human Physiology (ZIHP), Zurich, Switzerland

\section{Grants \& Funding}

This work was supported by the following grants:

- Swiss National Science Foundation (SNF): Grant 31003A 144212

- Swiss Lung Association: LLS-Nr 2014-09

- Hartmann Müller Foundation: Gesuch Nr 1843

- Novartis Foundation for medical-biological research: 16B086 
